UNIVERSIDADE DE SÃO PAULO

FACULDADE DE FILOSOFIA, LETRAS E CIENCIAS HUMANAS

DEPARTAMENTO DE LETRAS MODERNAS

PROGRAMA DE PÓS-GRADUAÇÃO EM LÍNGUA, LITERATURA E CULTURA ITALIANAS

GRAZIELLA SCHETTINO VALENTE

ENSINO DE LÍNGUAS BASEADO EM TAREFAS: O USO DO VÍDEO DE DIRE FARE PARTIRE! NO DESENVOLVIMENTO DA EXPRESSÃO ORAL DE APRENDIZES INICIANTES DE ITALIANO 


\title{
ENSINO DE LÍNGUAS BASEADO EM TAREFAS: O USO DO VIIDEO DE DIRE FARE PARTIRE! NO DESENVOLVIMENTO DA EXPRESSÃO ORAL DE APRENDIZES INICIANTES DE ITALIANO
}

\author{
Versão corrigida
}

Dissertação apresentada ao programa de PósGraduação em Língua, Literatura e Cultura Italianas do Departamento de Letras Modernas da Faculdade de Filosofia, Letras e Ciências Humanas da Universidade de São Paulo para a obtenção do título de Mestre em Letras.

Área de concentração: Língua, Literatura e Cultura Italianas

Linha de Pesquisa: Aquisição e Aprendizagem do Italiano como Língua Estrangeira

Orientadora: Profa. Dra. Giliola Maggio 
Autorizo a reprodução e divulgação total ou parcial deste trabalho, por qualquer meio convencional ou eletrônico, para fins de estudo e pesquisa, desde que citada a fonte.

Catalogação na Publicação

Serviço de Biblioteca e Documentação

Faculdade de Filosofia, Letras e Ciências Humanas da Universidade de São Paulo

V

Valente, Graziella Schettino

ENSINO DE LÍNGUAS BASEADO EM TAREFAS: O USO DO VÍDEO DE DIRE FARE PARTIRE! NO DESENVOLVIMENTO DA EXPRESSÃO ORAL DE APRENDIZES INICIANTES DE ITALIANO / Graziella Schettino Valente; orientadora Giliola Maggio - São Paulo, 2021. $125 \mathrm{f}$.

Dissertação (Mestrado)- Faculdade de Filosofia, Letras e Ciências Humanas da Universidade de São Paulo. Departamento de Letras Modernas. Área de concentração: Língua, Literatura e Cultura Italiana.

1. CH791 - LINGUÍSTICA. 2. CH791.5 - LINGUÍSTICA APLICADA - 3. CH791.5.2 - ENSINO DE LÍNGUA ESTRANGEIRA - 4. CH791.14.1 - APRENDIZAGEM DE LÍNGUA ESTRANGEIRA • I. Maggio, Giliola, orient. II. Título. 


\section{ENTREGA DO EXEMPLAR CORRIGIDO DA DISSERTAÇÃO/TESE \\ Termo de Ciência e Concordância do (a) orientador (a)}

Nome do (a) aluno (a): Graziella Schettino Valente

Data da defesa: 13/05/2020

Nome do Prof. (a) orientador (a): Giliola Maggio

Nos termos da legislação vigente, declaro ESTAR CIENTE do conteúdo deste EXEMPLAR CORRIGIDO elaborado em atenção às sugestões dos membros da comissão Julgadora na sessão de defesa do trabalho, manifestando-me plenamente favorável ao seu encaminhamento e publicação no Portal Digital de Teses da USP.

São Paulo, 10/07/2020

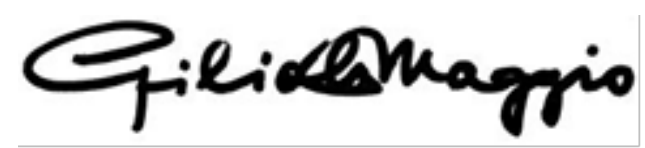

(Assinatura do (a) orientador (a) 


\section{AGRADECIMENTOS}

À minha querida orientadora, Giliola Maggio, por ter aberto as portas para que esse trabalho se realizasse, pelo norte e pela acolhida durante o percurso.

À carissima professora Roberta Ferroni, por sua dedicação amorosa às aulas e aos alunos, pelas oportunidades, sugestões, por todo aprendizado e apoio.

Às professoras Maria Helena de Araújo e Sá, Fernanda Ortale, Cristina Pietraróia, Eliane Lousada, Heloisa Costa, Mona Mohamad Hawi, pela acolhida nas suas disciplinas e pelo aprendizado. E às professoras Alessandra Ribeiro, Heloisa Costa, Roberta Ferroni, por suas perguntas e sugestões que enriqueceram este trabalho.

À professora Paola Baccin, por me receber em sua sala de aula para que eu pudesse conhecer na fonte o Dire, Fare, Partire!

Ao professor Raul César Gouveia Fernandes, professor da disciplina de Redação Científica no Centro Universitário FEI, São Bernardo do Campo/SP, quem ainda não tive a honra e a alegria de conhecer, mas que em muitos momentos guiou minha escrita, através dos materiais de suas aulas: grata pelo fio da meada no labirinto das minhas ideias.

Aos colegas da pós pela amizade, convivência, trocas e sugestões.

Às funcionárias do DLM e à Marta G. Campos, do Setor de Teses da Bilblioteca da FFLCH/USP, sempre prontas a auxiliar. Grata por sua delicadeza e disponibilidade.

Aos alunos que gentilmente participaram desta pesquisa, vocês são incríveis! E aos meus alunos, de ontem e de hoje, por me inspirarem e trazerem alegria ao meu trabalho. Vocês têm morada no meu coração.

À minha família e amigos, de perto e de longe, que estiveram sempre presentes, apoio certo nas horas incertas.

A você, Cris, que está sempre ao meu lado e com amor faz meus dias mais felizes. Sem você, eu não teria conseguido. Eu te amo!

Ao Divino Mestre e à Mãe Divina, por me clarearem o caminho. 


\section{RESUMO}

VALENTE, G. S. Ensino de Línguas Baseado em Tarefas: O uso do vídeo de Dire Fare Partire! no desenvolvimento da expressão oral de aprendizes iniciantes de italiano. 2020. 125 f. Dissertação (Mestrado) - Faculdade de Filosofia, Letras e Ciências Humanas, Universidade de São Paulo, 2021.

O objetivo deste estudo é verificar os benefícios do Ensino por Tarefas no desenvolvimento da expressão oral de aprendizes de italiano como língua estrangeira desde os níveis iniciantes. A fundamentação teórica consiste no Ensino de Línguas Baseado em Tarefas proposto por Michael Long, uma abordagem sintética com o foco na forma que tem como princípios metodológicos: o uso de tarefas, não textos, como unidades de análise; aprender fazendo; a elaboração do insumo; o contato com insumo rico; o incentivo da aprendizagem indutiva de chunks (parcelas); o foco na forma; o feedback negativo; o respeito aos currículos internos e processos de desenvolvimento do aluno; a aprendizagem colaborativa e cooperativa; e individualização da instrução. Outras teorias e abordagens que contribuem para este estudo são: a Hipótese do Input de Krashen, a Hipótese do Output de Swain, a Hipótese da Interação de Long, a competência comunicativa e o Ensino Comunicativo, a tipologia de tarefas de Willis. No que se refere à fundamentação metodológica, trata-se de um estudo etnográfico das relações e interações verbais que acontecem na sala de aula. Para se realizar este estudo, foram elaboradas tarefas pedagógicas com o objetivo de oferecer oportunidades de desenvolvimento da expressão oral para uma turma de italiano 2 (nível A1-A2 do Quadro Europeu Comum de Referência para as Línguas) em uma faculdade de letras de São Paulo, a partir dos vídeos de Dire Fare Partire! - material didático multimídia, produzido especificamente para o público brasileiro, disponibilizado on-line gratuitamente pela USP. A análise dos dados coletados parece indicar que a realização de tarefas pedagógicas, elaboradas a partir das necessidades dos aprendizes, pode trazer benefícios para a aquisição de línguas estrangeiras, principalmente no que diz respeito ao desenvolvimento da expressão oral, na medida em que promove comunicação real, através da aprendizagem colaborativa, do monitoramento pessoal e cooperativo da conversa, do foco na forma condizente com o estágio de desenvolvimento dos aprendizes, motivados por seus objetivos e interesses pessoais.

Palavras-chave: Ensino por tarefas. Interação verbal. Expressão oral. Trabalho em grupo. 


\begin{abstract}
VALENTE, G. S. Task-based language teaching: using videos from Dire Fare Partire! in the development of Italian learners' oral expression as a foreign language from beginner levels 2020. 125 f. Master's Thesis - Faculty of Philosophy, Languages and Human Sciences at University of, São Paulo, 2021.

The aim of this study is to verify the benefits of teaching by tasks in the development of Italian learners' oral expression as a foreign language from beginner levels. The theoretical foundation consists of Task-Based Language Teaching proposed by Michael Long, a synthetic approach with focus on form which there are some methodological principles, such as: use of tasks, not texts, as units of analysis; learning by doing; preparation of the input; contact with rich input; encouragement of inductive learning of chunks; focus on form; negative feedback; respect for the student's internal curricula and development processes; collaborative and cooperative learning; and individualization of instruction. Other theories and approaches, which have contributed to the present study, are: Krashen's Input Hypothesis, Swain's Output Hypothesis, Long's Interaction Hypothesis, communicative competence and communicative teaching, Willis's task typology. As far as the methodological foundation is concerned, it is an ethnographic study of the relationships and the verbal interactions that take place in the classroom. In order to carry out this study, pedagogical tasks were developed with the objective of offering opportunities for the development of oral expression for a class of Italian 2 learners (level A1-A2 of the Common European Framework of Reference for Languages) in a College for Linguistics in São Paulo, using videos from Dire Fare Partire! multimedia didactic material that is produced specifically for Brazilian public and is available online for free by USP. The analysis of the collected data seems to indicate that the accomplishment of pedagogical tasks, elaborated from the needs of the apprentices, can bring benefits for the acquisition of foreign languages, mainly regarding the development of oral expression, to the extent that it promotes real communication, through collaborative learning, personal and cooperative monitoring of the conversation, focus on the form according to the stage of development of the learners, motivated by their personal goals and interests.
\end{abstract}

Keywords: Task-based language teaching. Interaction. Oral expression. Peer work. 


\section{RIASSUNTO}

VALENTE, G. S. L'insegnamento di lingue attraverso task: L'uso del video di Dire Fare Partire! nello svilupo dell'espressione orale di apprendenti inizianti di italiano. 2020. $125 \mathrm{f}$. Tesi (Master) - Facoltà di Filosofia, Lettere e Scienze Umane dell'Università di San Paolo, San Paolo, 2021.

L'obiettivo di questo studio è verificare i benefici dell'insegnamento attraverso task nello sviluppo dell'espressione orale di studenti di italiano come lingua straniera dai livelli iniziali. La base teorica è l'Insegnamento delle Lingue Basato sui Task proposto da Michael Long, un approccio analitico con attenzione alla forma che ha come principi metodologici: usare task, non di testi, come unità di analisi; imparare facendo; elaborare l'input; fornire input ricco; incoraggiare l'apprendimento induttivo dei chunks; l'attenzione alla forma; il feedback negativo; rispetto ai curricula interni ed ai processi di sviluppo dello studente; apprendimento collaborativo e cooperativo; e individualizzazione dell'istruzione. Altre teorie e approcci che contribuiscono a questo studio sono: l'Ipotesi del Input di Krashen, l'Ipotesi del Output di Swain, l'Ipotesi dell'Interazione di Long, la competenza comunicativa e l'insegnamento comunicativo e la tipologia di task di Willis. Per quanto riguarda la base metodologica, si tratta di uno studio etnografico delle relazioni e delle interazioni verbali che si svolgono in classe. Per realizzare questo studio, sono stati elaborati task pedagogici con l'obiettivo di offrire opportunità per lo sviluppo dell'espressione orale in una classe di italiano 2 (livello A1-A2 del Quadro Europeo Comune di Riferimento per le Lingue) in una facoltà di lettere a San Paolo, partendo dai video di Dire, Fare. Partire! - un materiale didattico multimediale, prodotto propriamente per il pubblico brasiliano, disponibile gratuitamente sul sito della USP. L'analisi dei dati raccolti sembra indicare che il lavoro con task pedagogici, elaborati dalle esigenze degli apprendisti, può portare benefici per l'acquisizione di lingua straniera, principalmente per quanto riguarda lo sviluppo dell'espressione orale, in quanto promuove comunicazione reale, attraverso l'apprendimento collaborativo, il monitoraggio personale e cooperativo della conversazione, l'attenzione sulla forma adeguata alla fase di sviluppo degli studenti, motivati dai loro obiettivi ed interessi personali.

Parole chiave: Insegnamento per task. Interazione verbale. Espressione orale. Lavoro di gruppo. 


\section{LISTA DE ABREVIATURAS E SIGLAS}

CA competência acional

$\mathrm{CC}$ competência comunicativa

CCon competência conversacional

CD competência discursiva

CE competência estratégica

CI competência interacional

CL competência linguística

CLT Communicative Language Teaching (Ensino Comunicativo)

CS competência sociolinguística

CSC competência sociocultural

DFP Dire, Fare, Partire!

ES estrangeirismo

F inicial para identificar aprendiz

FFLCH Faculdade de Filosofia, Letras e Ciências Humanas

G inicial para identificar aprendiz

IL interlíngua

L1 primeira língua

L2 segunda língua

LA língua-alvo

LE língua estrangeira

LM língua materna

M inicial para identificar aprendiz

PC professora da classe

PP professora-pesquisadora

QECR Quadro Europeu Comum de Referência para as Línguas

QECRL Quadro Europeu Comum de Referência para as Línguas

QI quociente de inteligência

$\mathrm{R} \quad$ inicial para identificar aprendiz

$\mathrm{T} \quad$ inicial para identificar aprendiz

T1-T27 turnos

TBLT Task Based Language Teaching (Ensino de Línguas Baseado em Tarefas) TF transferência fonética 
TL tradução literal

TR transferência

TV televisão

USP Universidade de São Paulo

V inicial para identificar aprendiz 


\section{LISTA DE FIGURAS}

Figura 1. Folha de atividades da tarefa pedagógica

Cercando Lavoro p. 57

Figura 2. Folha de atividades da tarefa pedagógica

Cercando Lavoro: L'abito non fa il monaco (página 1) p.60

Figura 3. Folha de atividades da tarefa pedagógica

Cercando Lavoro: L'abito non fa il monaco (página 2) p.61

Figura 4. Folha de atividades das tarefas pedagógicas

Ospitalità e Mangia che ti fa bene! p.64

Figura 5. Folha de atividades da tarefa pedagógica

Chi ha lingua va a Roma (página 1) p.66

Figura 6. Folha de atividades da tarefa pedagógica

Chi ha lingua va a Roma (página 2) p.67 


\section{LISTA DE TABELAS}

Tabela 1. Uso de monitor e de feedback positivo ................................................ 68

Tabela 2. Uso de monitor para correção de item linguístico .................................... 68

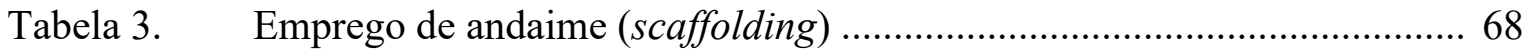

Tabela 4. Distribuição de turno e feedback corretivo ................................................. 69

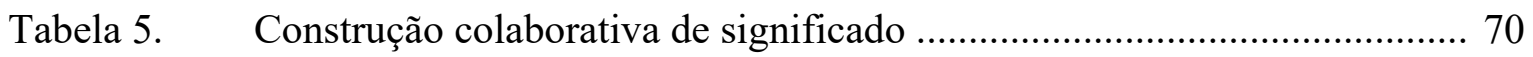

Tabela 6. Aprendizagem colaborativa: ampliando o léxico ................................... 70

Tabela 7. Aprendizagem colaborativa: expressando as próprias opiniões ................ 71

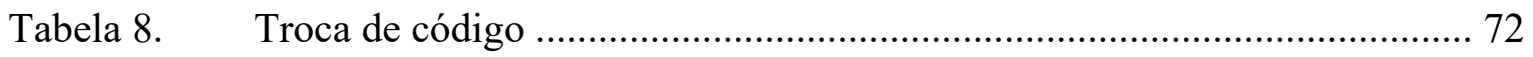

Tabela 9. Troca de código, monitoramento pessoal e aprendizagem colaborativa .... 73

Tabela 10. Ato de identidade (ironia), lapsi autorreparados, uso do monitor ............... 74

Tabela 11. Ato de identidade (ironia) e troca de código ..............................................75

Tabela 12. Distribuição de turno, troca de código, monitoramento pessoal e cooperativo .................................................................................. 76

Tabela 13. Transferência, monitoramento pessoal e monitoramento cooperativo ....... 77

Tabela 14. Trocas de código, estrangeirismo, transferência e transferência fonética .. 78

Tabela 15. Foco na forma através da aprendizagem colaborativa:

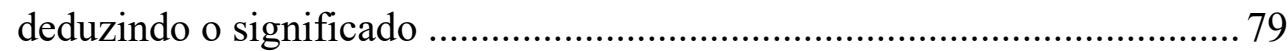

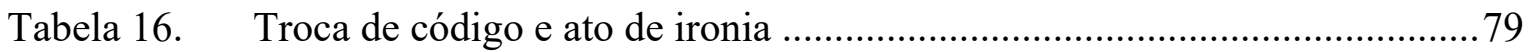

Tabela 17. Foco na forma com monitoramento cooperativo ........................................ 80

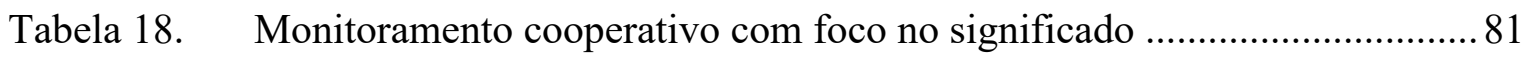

Tabela 19. Foco no significado com troca de tradução, tradução literal, tranferência e transferência fonética ....................................................... 83

Tabela 20. Aprendizagem colaborativa: foco no significado e foco na forma............... 84

Tabela 21. Aprendizagem colaborativa: foco no significado e troca de código ...........85

Tabela 22. Trasferência consciente como estratégia de comunicação e aprendizagem 86

Tabela 23. Post-task: feedback e foco na forma ..................................................... 87

Tabela 24. Foco no significado e monitoramento cooperativo ................................. 88

Tabela 25. Foco no significado e transferência consciente:

troca de código e troca de tradução

Tabela 26. Foco no significado e transferência consciente:

troca de código e transferência fonética 
INTRODUÇÃO .................................................................................................................. 16

1 ENSINO COMUNICATIVO E ENSINO POR TAREFAS .............................................. 18

1.1 Aquisição e aprendizagem de línguas não maternas................................................20

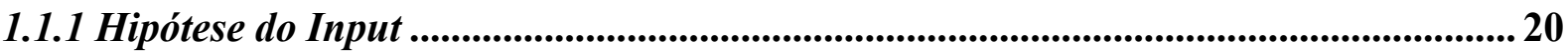

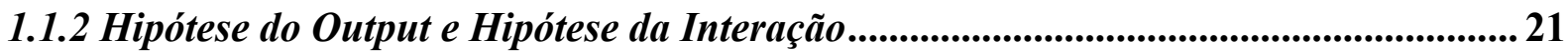

1.2 Ensino Comunicativo: o ensino de línguas para a comunicação ................................... 24

1.3 Ensino por Tarefas: o ensino de línguas através da comunicação..............................25

1.4 Abordagens Sintéticas e Analíticas no Ensino de Línguas ............................................. 26

1.4.1 Abordagens Sintéticas ................................................................................................... 26

1.4.2 Abordagens Analíticas ....................................................................................................... 28

1.4.3. Fragilidades das Abordagens Sintéticas e Analíticas .................................................... 29

1.5 Abordagem Analítica com foco na forma: o Ensino de Línguas Baseado em Tarefas

1.5.1 Princípios Metodológicos ..................................................................................................... 35

1.5.1.1. Usar tarefas, não textos, como unidades de análise ............................................... 35

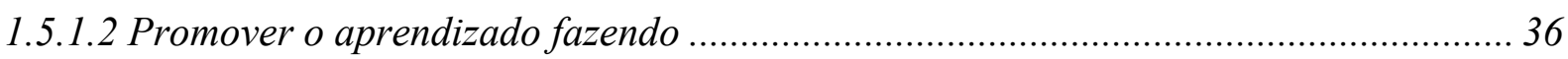

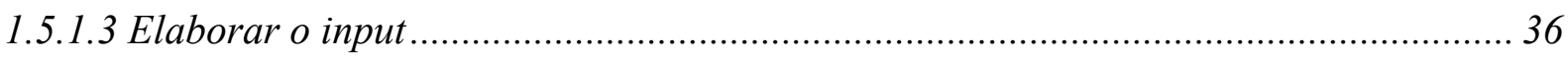

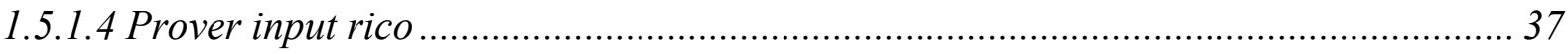

1.5.1.5 Encorajar a aprendizagem indutiva de chunks ou parcelas ..................................... 38

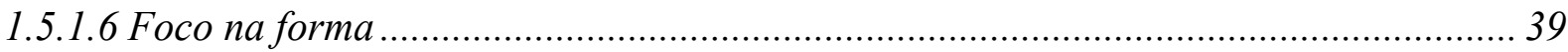

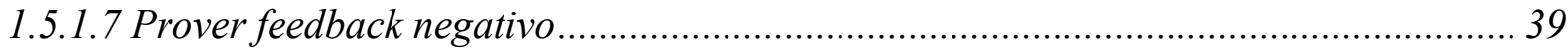

1.5.1.8 Respeitar os currículos internos e os processos de desenvolvimento do aluno........... 41

1.5.1.9 Promover a aprendizagem cooperativa colaborativa ............................................ 41

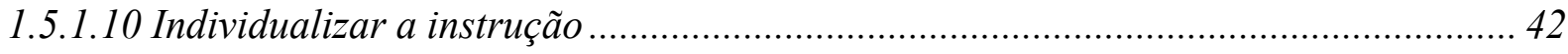

1.5.2 Procedimentos Pedagógicos............................................................................................... 43 


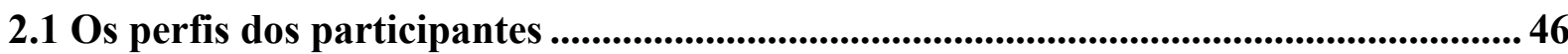

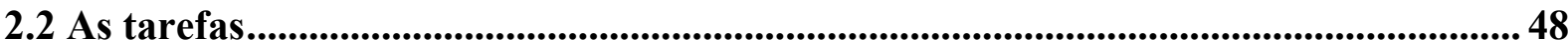

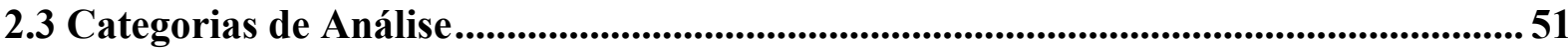

3 INTERAÇÃO VERBAL ENTRE APRENDIZES DURANTE A REALIZAÇÃO DE TAREFAS .54

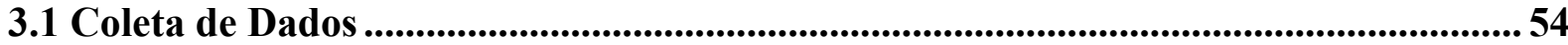

3.2 Tarefas Pedagógicas elaboradas a partir dos vídeos de Dire Fare Partire! ................. 55

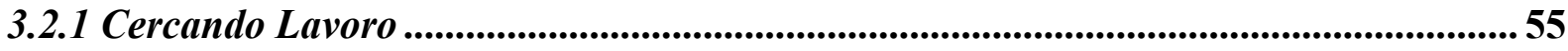

3.2.2 Cercando Lavoro: L'abito non fa il monaco...................................................................... 58

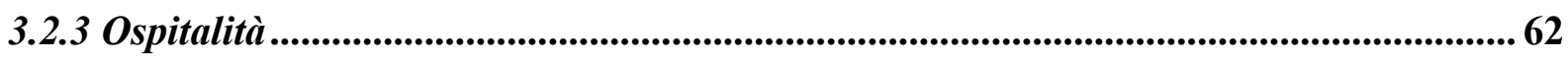

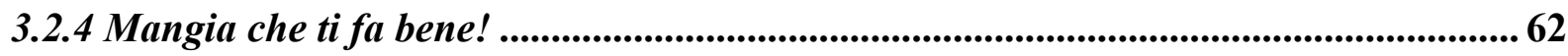

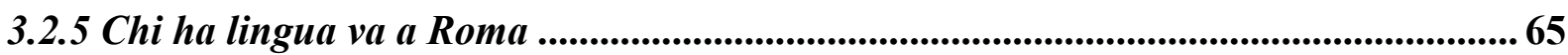

3.3 Análise da interação entre os aprendizes durante a tarefa Cercando Lavoro............. 68

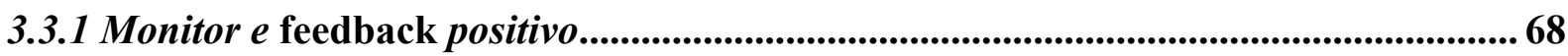

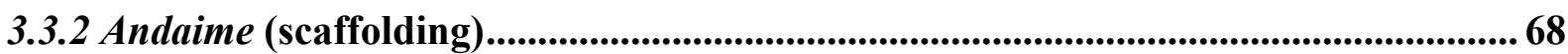

3.3.3 Distribuição de turno e feedback negativo ..............................................................69

3.3.4 Aprendizagem colaborativa: construindo o significado ............................................ 70

3.3.5 Aprendizagem colaborativa: ampliando o léxico ............................................................... 70

3.3.6 Aprendizagem colaborativa: expressando as próprias opiniões ................................. 71

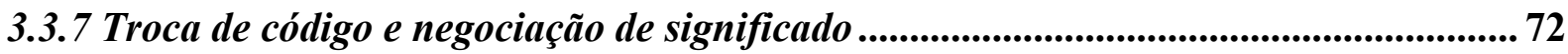

3.3.8 Atos de identidade (ironia) e troca de código .................................................................... 74

3.4 Análise da interação entre os aprendizes durante a tarefa $L$ 'abito non fa il monaco 75 3.4.1 Distribuição de turno, atos de identidade (ironia), troca de código, monitoramento.. 75 3.4.2 Monitoramento pessoal, monitoramento cooperativo, feedback negativo e transfer.76 3.4.3 Trocas de código, estrangeirismo, transferência e transferência fonética ...................77 3.4.4 Aprendizagem colaborativa: deduzindo o significado do léxico ................................79

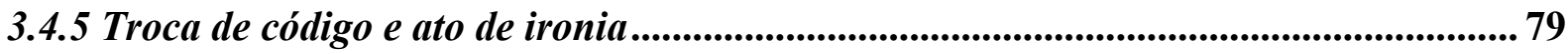


3.5 Análise da interação entre os aprendizes durante a tarefa $O$ spitalità .......................... 81

3.5.1 Aprendizagem colaborativa: Foco no significado .....................................................81

3.6 Análise da interação entre os aprendizes durante a tarefa Mangia che ti fa bene!.... 84

3.6.1 Aprendizagem colaborativa: foco no significado e foco na forma................................ 84

3.6.2 Aprendizagem colaborativa: foco no significado e troca de código .............................85

3.6.3 Post-task: provendo foco na forma através de feedback do professor.......................... 86

3.6.4 Aprendizagem colaborativa: foco no significado e monitoramento cooperativo.......... 88

3.7 Análise da interação entre os aprendizes durante a tarefa Chi ha lingua va a Roma 90

3.8 Da interação entre os aprendizes durante a realização de tarefas ...............................91

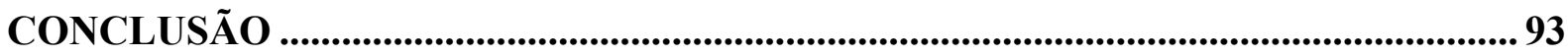

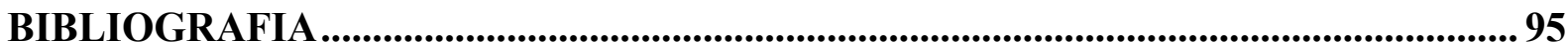

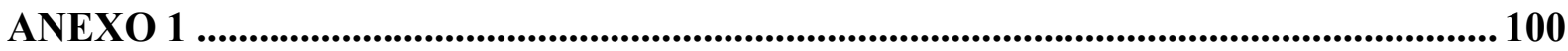

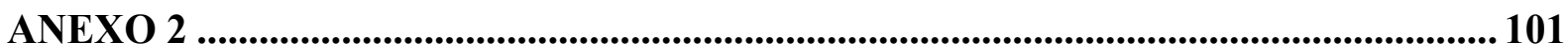

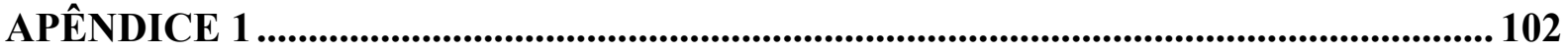

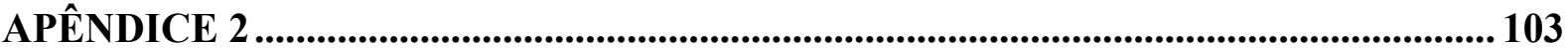

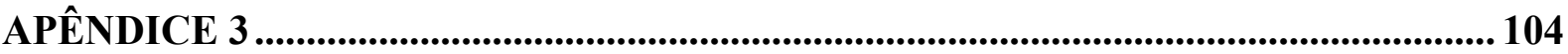

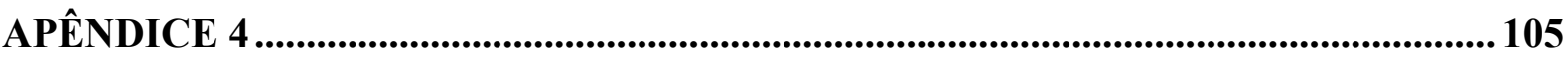

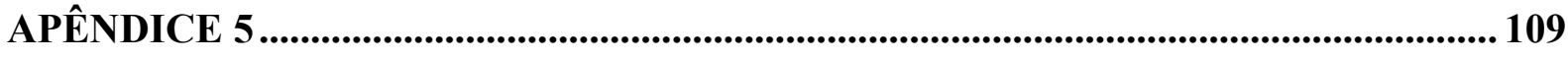

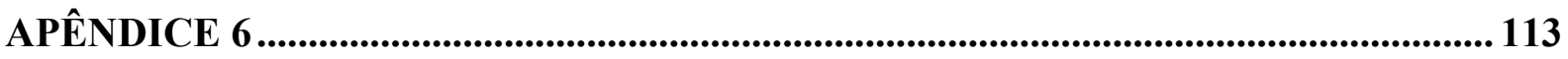

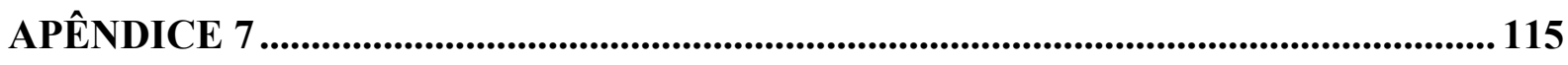

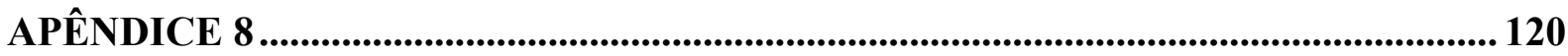




\section{INTRODUÇÃO}

Nos dias atuais, com o advento da internet e da globalização, o contato com línguas estrangeiras $^{1}$ é cada vez mais comum e poder se comunicar em outro idioma é uma habilidade que muitos almejam. A necessidade sempre crescente de "comunicar-se bem" gerou uma grande demanda em todo o mundo: dos pais que desejam atingir um domínio de uma língua estrangeira (LE) e dar a mesma oportunidade a seus filhos, aos empregadores que exigem de seus empregados fluência em outro idioma² (RICHARDS, 2006).

Muitas são as opções de materiais didáticos e cursos, virtuais e presenciais, para a aprendizagem de LE. As relações comerciais e políticas entre os países nos cinco continentes e a crescente migração que se testemunha na atualidade reforçam a necessidade de se comunicar com o outro e despertam o interesse por outras culturas. A Europa tem se ocupado da delicada questão da imigração em massa que está em curso, e a Itália, por sua posição geográfica, desempenha um papel central, sendo uma porta de entrada no continente para aqueles que ali aportam na esperança de dias melhores para si e suas famílias.

$\mathrm{O}$ interesse pela língua e cultura italianas está nas relações de trabalho - indústria automobilística, tecnologia, telecomunicações, gastronomia, moda, design, arte, história, música, literatura, direito, medicina - mas ocupa também o lugar das memórias afetivas: a Itália, que hoje recebe um número crescente de imigrantes, no passado viu tantas de suas famílias emigraram em busca de novas oportunidades em países estrangeiros, e muitas encontraram no Brasil um novo lar. Tantos, aqui, são os descendentes que desejam visitar seus familiares italianos, falar a língua de seus antepassados ${ }^{3}$ e conhecer suas origens.

Na minha experiência docente, tenho percebido que o principal interesse dos alunos, quando começam um curso de língua, é a interação oral, mas, após anos de estudo, alguns chegam a desenvolver mais as habilidades de produção escrita e de compreensão do que a expressão oral; adquirem um bom conhecimento das estruturas da língua, porém, demonstram insegurança ou pouca fluência para falar a língua-alvo (LA). Dessa observação surgiu-me a

\footnotetext{
${ }^{1}$ A língua materna (LM), também chamada primeira língua (L1), é aquela adquirida durante a infância, no local de nascimento da criança - em comunidades multilíngues, é aquela que a criança se sente mais confortável para usar (RICHARDS; SCHMIDT, 2013). Uma língua não materna também é chamada segunda língua (L2) quando adquirida no país onde é falada e língua estrangeira (LE) quando aprendida, em outro país. O italiano adquirido por brasileiros na Itália é considerado L2; mas, no caso desta pesquisa, em que brasileiros aprendem italiano no Brasil, é considerado LE. Ambas, L2 e LE, podem, ainda, ser chamadas língua-alvo (LA). No presente trabalho, o termo LE é empregado para denominar uma língua não materna e, ao referenciar outros autores, procura-se manter o termo empregado originalmente.

${ }^{2}$ Richards (2006) trata especificamente do inglês como L2.

${ }^{3}$ Nesse sentido, há o Ensino do Italiano como Língua de Herança, cuja pesquisa, iniciada em 2015 por Ortale (2016), traz um novo olhar para o ensino de LE, voltado para comunidades de descendentes.
} 
pergunta: como favorecer o desenvolvimento da expressão oral já nos níveis iniciantes de italiano?

Partindo da hipótese que o Ensino de Línguas Baseado em Tarefas (LONG, 2015), elaboradas a partir das necessidades dos aprendizes, favorece a aquisição de segunda língua (L2) através da comunicação e acreditando que o desenvolvimento da expressão oral também se faz por meio da interação na LA, esta pesquisa tem como objetivo verificar os efeitos do uso de tarefas pedagógicas na aprendizagem de italiano como LE, pela análise da interação verbal entre os aprendizes durante a realização de tarefas elaboradas a partir dos vídeos de Dire, Fare, Partire! (DFP) ${ }^{4}$ - uma série de ficção que aborda questões linguísticas e culturais de um brasileiro que estuda italiano no Brasil.

Nas interações analisadas, há a participação de seis alunos de uma turma de Italiano 2, nível A1-A2 do Quadro Europeu Comum de Referência para as Línguas ${ }^{5}$ (QECRL) de uma faculdade de Letras em uma universidade no estado de São Paulo, durante a realização de cinco tarefas pedagógicas, em seis encontros com a duração de cerca de 45 minutos cada.

O presente trabalho é um estudo etnográfico que visa a observação da interação verbal no contexto da sala de aula de LE, buscando compreender como acontecem as aulas baseadas nas tarefas propostas. Estrutura-se em três capítulos.

No Capítulo 1, Ensino Comunicativo e Ensino por Tarefas, apresentam-se as bases teóricas que fundamentam o Ensino por Tarefas adotado nesta pesquisa (LONG, 2015). No Capítulo 2, Metodologia, apresentam-se os fundamentos metodológicos que nortearam esta pesquisa etnográfica (VAN LIER, 1988), seu contexto, o perfil de seus participantes, as categorias de análise e as normas de transcrição da interação (FERRONI 2012). No Capítulo 3, Interação verbal entre aprendizes durante a realização de Tarefas, analisam-se e comentamse as tarefas pedagógicas fundamentadas nos Princípios Metodológicos do Ensino de Línguas Baseado em Tarefas (LONG, 2015), elaboradas a partir dos vídeos de DFP e utilizadas nas aulas, e a interação verbal entre os alunos, com o objetivo de observar essa comunicação e verificar de que maneira as tarefas propostas possam ter contribuído para o desenvolvimento da expressão oral dos aprendizes, no primeiro ano do curso de italiano como LE.

$\mathrm{Na}$ Conclusão, é apresentada a perspectiva da pesquisadora a respeito do tema, a partir das análises e observações realizadas durante este estudo.

\footnotetext{
${ }^{4}$ DFP é um conjunto de materiais didáticos elaborado para o ensino e aprendizagem da língua italiana como LE, sob a coordenação didática da Profa. Dra. Paola Baccin, produzido pelo Programa de Pós-Graduação em Língua, Literatura e Cultura Italianas da FFLCH/USP em parceria com a Superintendência de Tecnologia da Informação/Diretoria de Mídias Digitais da USP (UNIVERSIDADE DE SÃO PAULO, [201-]).

${ }^{5}$ CONSELHO DA EUROPA, 2001.
} 


\section{ENSINO COMUNICATIVO E ENSINO POR TAREFAS}

A competência linguística é uma dimensão importante da aprendizagem de línguas, mas não é suficiente: conhecer as regras gramaticais não significa necessariamente ser capaz de se comunicar de maneira eficaz (WIDDOWSON, 1978). Assim, a partir da década de 1970, o tema competência comunicativa vem sendo tratado por diversos autores, visando ao aprimoramento das técnicas, métodos e abordagens ${ }^{6}$ de ensino e aprendizagem de línguas.

A competência comunicativa, segundo Hymes (1972), tem uma dimensão linguística e uma dimensão sociolinguística, definida na relação com o outro, no contexto de uma comunidade linguística específica. $\mathrm{O}$ autor considera "[...] competência como o termo mais geral para as capacidades de uma pessoa. [...] Competência depende tanto de conhecimento (tácito) quanto de (habilidade de) uso"7 (p. 282) ${ }^{8}$. Nessa visão, além das regras gramaticais, são igualmente importantes as regras de uso e de atos de fala: saber se (e quando) algo é formalmente possível, viável, apropriado e feito (com que frequência). Por exemplo, "[...] uma sentença pode ser gramatical, estranha, diplomática e rara"9 (p. 281). Portanto, é necessário aplicar o conhecimento linguístico de maneira adequada ao contexto para que a comunicação seja bem-sucedida.

Além das competências linguística (CL) e sociolinguística ${ }^{10}(\mathrm{CS})$, posteriormente foram identificadas outras dimensões da competência comunicativa (CC): a competência estratégica (CE), uso de estratégias de comunicação verbais e não verbais para suprir lacunas na CL e CS (CANALE e SWAIN, 1980); a competência discursiva (CD), "como combinar formas gramaticais e significados para alcançar um texto unificado, falado ou escrito, em diferentes gêneros [...] através de coerência na forma e coesão no significado"11 (CANALE, 1983, p. 9); e a competência interacional (CI), que se compõe da competência acional (CA), a

\footnotetext{
${ }^{6}$ Abordagem pode ser definida como o conjunto de teorias, filosofias e princípios que norteiam as práticas de ensino, refletindo uma visão a respeito da natureza das línguas e como elas são aprendidas. Diferentes visões, as abordagens, implicam em diferentes modos de ensinar, os métodos, que implicam em diferentes tipos de atividades realizados em sala de aula, as técnicas. (RICHARDS; SCHIMIDT, 2013).

7 "[...] competence as the most general term for the capabilities of a person. [...] Competence is dependent upon both (tacit) knowledge and (ability for) use."

${ }^{8}$ Esta e as demais traduções neste trabalho são nossas.

9 "[...] a sentence may be grammatical, awkward, tactful e rare."

${ }^{10}$ CS também é chamada competência sociocultural (CSC), ao se levar em consideração "o conhecimento cultural necessário para interpretar e usar a língua de modo eficiente" - "the cultural background knowledge needed to interpret and use a language effectively" (CELCE-MURCIA, 2007, p. 42).

11 "how to combine grammatical forms and meanings to achieve a unified spoken or written text in different genres [...] through cohesion in form and coherence in meaning."
} 
habilidade de compreender e produzir atos de fala ${ }^{12}$, e da competência conversacional (CCon), inerente ao sistema de tomada de turnos (CELCE-MURCIA, 2007).

Em Teaching Language as Communication ${ }^{13}$, Widdowson (1978) destaca a importância da natureza do discurso e das habilidades envolvidas na sua criação para o desenvolvimento de uma abordagem de ensino de línguas que conduza à habilidade de comunicar. Distingue a forma (usage - capacidade de formar frases gramaticalmente corretas) do uso (use - capacidade de utilizar tais frases de maneira adequada para uma comunicação eficaz) e considera ambos aspectos importantes do desempenho do aprendiz (performance), que devem ser levados em consideração na elaboração de material didático.

O Ensino Comunicativo de Línguas, Communicative Language Teaching (CLT), é definido por Richards "como um conjunto de princípios a respeito dos objetivos do ensino de línguas, como os aprendizes aprendem uma língua, os tipos de atividades em sala de aula que mais favorecem o aprendizado e os papéis de professores e aprendizes na sala de aula"14 (2006, p. 2). Com o foco das aulas no desenvolvimento das habilidades comunicativas, o aprendiz passa a desempenhar o papel central na aprendizagem. O professor é o facilitador, o monitor nas atividades comunicativas que proporcionam mais interação entre os alunos, aumentando a responsabilidade dos aprendizes pela própria aprendizagem.

No processo de ensinar e aprender outras línguas, Almeida Filho (1998) identifica cinco principais fatores: abordagem do material de ensino, filtro afetivo do professor, abordagem de ensinar do professor, abordagem de aprender do aluno e filtro afetivo do aluno. $\mathrm{O}$ autor afirma que aprender uma língua estrangeira abrange "[...] configurações especificas de afetividade (motivações, capacidade de risco, grau de ansiedade, pressão do grupo) com relação à essa língua-alvo que se deseja e/ou necessita aprender.” (p.15). Para ele, ensinar língua estrangeira (LE) implica uma visão condensada e moderada por afetividade enquanto aprender LE significa "crescer numa matriz de relações interativas na língua-alvo que gradualmente se desestrangeiriza para quem a aprende.” (ALMEIDA FILHO, 1998, p.15).

\footnotetext{
${ }^{12}$ Hymes (1972) considerou o uso dos atos de fala como uma característica da competência sociolinguística.

${ }^{13}$ Literalmente, Ensinando língua como comunicação, publicado no Brasil com o título $O$ ensino de línguas para a comunicação (WIDOWSON, 1991).

14 "Communicative language teaching can be understood as a set of principles about the goals of language teaching, how learners learn a language, the kinds of classroom activities that best facilitate learning, and the roles of teachers and learners in the classroom."
} 


\subsection{Aquisição e aprendizagem de línguas não maternas}

Nesta sessão são apresentadas algumas hipóteses de aquisição e aprendizagem de línguas não maternas, conhecidas como Hipótese do Input (KRASHEN, 1981, 1982, 1985, 1991, 2009), Hipótese da Interação (LONG, 1981, 1983, 2015) e Hipótese do Output (SWAIN, 1985).

\subsubsection{Hipótese do Input}

A teoria de aquisição de L2 descrita por Krashen (1982) compõe-se de cinco hipóteses: Hipótese da Aquisição-Aprendizagem, Hipótese da Ordem Natural, Hipótese do Monitor, Hipótese do Input e Hipótese do Filtro Afetivo - sendo a Hipótese do Input o ponto central de sua teoria.

Krashen (1982) diferencia aquisição de aprendizagem, afirmando que há dois modos distintos de desenvolver competência em línguas: um subconsciente, implícito, e outro consciente, explícito. Para o autor, a aquisição é um processo subconsciente de desenvolvimento através da vivência, em que se percebe que algo soa bem ou não na L2, sem que se saiba precisar ou descrever as regras empregadas no uso da língua para a comunicação: “Outras maneiras de descrever a aquisição incluem aprendizagem implícita, aprendizagem informal e aprendizagem natural." ${ }^{15}$ (KRASHEN, 2009, p.10). A aprendizagem, por outro lado, envolve um conhecimento explícito das regras em uso, estar consciente delas e saber falar sobre elas; um saber decorrente de conhecimento formal da língua, ou de aprendizagem explícita. Na aprendizagem, como estabelece a Hipótese do Monitor (KRASHEN, 1985), o conhecimento explícito pode ser usado apenas para monitorar e editar a própria produção, seja ela oral ou escrita. Para tanto, além de se conhecer a regra, deve-se preocupar conscientemente com a exatidão e a correção da produção, condições que dificilmente se encontram. ${ }^{16}$

A Hipótese de Aquisição-Aprendizagem (KRASHEN, 1982) aponta que adultos podem adquirir línguas de maneira natural, mas isso não significa que irão alcançar níveis na L2 semelhantes à L1. Duas condições são necessárias para essa aquisição: input ou insumo

\footnotetext{
15 "Other ways of describing acquisition include implicit learning, informal learning, and natural learning."

${ }^{16}$ No presente trabalho, compreende-se que aquisição e aprendizagem são processos inerentes ao Ensino de Línguas, sendo o termo aquisição empregado para se referir à momentos de aprendizagem implícita, inconsciente, durante a realização de tarefas pedagógicas em sala de aula, e o termo aprendizagem empregado em sentido mais amplo, se referindo ao desenvolvimento de competências na LA.
} 
compreensível e filtro afetivo baixo ou fraco, que permita a entrada desse insumo. Krashen afirma que o ensino de línguas pode auxiliar a aquisição quando a sala de aula é a principal fonte de input compreensível de baixo filtro afetivo, especialmente em níveis iniciantes ou quando o aprendiz não tem a vivência da LE ou da L2 fora da sala de aula.

A Hipótese do Input (KRASHEN, 1985) atesta que o aprendiz deve ter suficiente exposição à língua e que o insumo compreensível deve conter algo ligeiramente acima do nível do aprendiz, fazendo-o avançar do nível em que se encontre $(i)$ até o próximo nível da ordem natural de aquisição ${ }^{17}(i+1)$. Se a exposição é suficiente e o input é compreendido, então "[...] a gramática necessária é automaticamente disponibilizada."18 (KRASHEN, 1985, p.2). Nessa visão, o falar é um resultado da aquisição da língua, o qual '[...] 'emerge' por si mesmo como um resultado da construção da competência por meio do insumo compreensível."19 (KRASHEN, 1985, p.2).

O input compreensível é condição necessária, mas não é suficiente. Para que a aquisição aconteça, é necessário que os aprendizes apresentem um baixo filtro afetivo, ou seja, eles precisam estar bastante motivados, ter autoconfiança, uma boa imagem de si mesmos, e baixos níveis de ansiedade. A Hipótese do Filtro Afetivo, que segundo Krashen (2009) teria sido apresentada pela primeira vez por Dulay e Burt (1977) ${ }^{20}$, indica que variáveis afetivas como motivação, autoconfiança e ansiedade influenciam diretamente na aquisição de L2 (KRASHEN, 2009).

\subsubsection{Hipótese do Output e Hipótese da Interação}

Swain (1985) descreve uma pesquisa realizada em uma escola no Canadá com crianças do $6^{\circ}$ ao $9^{\circ}$ ano do ensino fundamental, cuja LM é o inglês e que estavam aprendendo o francês como L2 em uma escola com um programa de imersão na língua-alvo.

Foram investigados três componentes de proficiência linguística, as competências gramatical, também chamada linguística (CL), discursiva (CD) e sociolinguística (CS), através de atividades de produção oral, testes de múltipla escolha e atividades de produção escrita, com o objetivo de determinar em que medida tais competências seriam identificadas

\footnotetext{
${ }^{17}$ A hipótese da ordem natural (KRASHEN, 1985) afirma que as regras de uma língua são adquiridas em certa ordem - determinada pelo currículo interno (built-in syllabus) do aprendiz (CORDER, 1967) - e que algumas regras tendem a serem adquiridas antes de outras.

18 "[...] the necessary grammar is automatically provided."

19 "[.... 'emerges' on its own as a result of building competence via comprehensible input."

${ }^{20}$ DULAY, H.; BURT, M. Remarks on creativity in language acquisition. In: BURT, M.; DULAY, H.; FINNOCHIARO, M. (Eds.) Viewpoints on English as a Second Language. New York: Regents, 1977. p. 95126.
} 
empiricamente e manifestadas diferencialmente no desempenho de alunos nativos e não nativos em ambiente de imersão em língua francesa.

Comparando seus desempenhos, verificou-se que os alunos não nativos alcançaram bons resultados, mas não desenvolveram a CL como os alunos nativos. $\mathrm{Na} \mathrm{CD}$, definida como a habilidade de produzir e reconhecer textos coerentes e coesos, a diferença notada nos resultados entre os dois grupos de alunos foi mínima, indicando uma distinção entre o traço discursivo e o gramatical. Na CS, por sua vez, definida como a habilidade de produzir e reconhecer o uso apropriado da linguagem em diferentes contextos socioculturais, o desempenho dos aprendizes em imersão foi tão bom quanto a dos alunos nativos nos casos em que é possível usar expressões formulaicas (expressões fixas e não literais) de cortesia. Mas nas categorias em que é necessário o conhecimento gramatical, para expressar gentilmente um pedido através do uso do condicional por exemplo, novamente os aprendizes em imersão tiveram um desempenho inferior à dos alunos nativos. E nos casos em que se espera o uso de marcadores formais de cortesia, como o emprego da forma vous para os alunos se dirigirem aos professores, verificou-se que os aprendizes em imersão fizeram uso do registro informal, com o emprego de $t u$, para se dirigirem aos colegas e professores, indistintamente.

A autora justifica que essa ausência do uso do marcador formal de cortesia vous teria uma ligação com o input recebido pelos alunos não nativos: tanto os professores quanto seus colegas se dirigem a eles usando o marcador informal $t u$. Enquanto o uso de vous podia ser observado apenas quando seus colegas nativos se dirigiam aos professores. Esse exemplo demonstra que, havendo poucas oportunidades de observar o uso do marcador formal e muitas do marcador informal, os aprendizes em imersão haviam internalizado apenas o uso deste, por não terem recebido insumo suficiente para a aquisição daquele, como atesta a Hipótese do Input (KRASHEN, 1981).

Por outro lado, nos testes e atividades que avaliaram sua habilidade linguística, Swain sugere que o baixo desempenho dos alunos não nativos não se deve à ausência de input compreensível, pois já estudavam a língua alvo em contexto de imersão há 7 anos e, ao longo do ensino fundamental, recebiam cada vez mais insumo de seus professores durantes as aulas, especialmente nos últimos anos em que mais tempo da aula é dedicado à fala do professor, ao transmitir os conteúdos curriculares das várias disciplinas escolares.

Os alunos não nativos tiveram um desempenho tão bom quanto os nativos nos exames das disciplinas escolares, bem como nos testes e atividades dessa pesquisa que avaliaram sua habilidade discursiva, demostrando que o input recebido era compreensível, além de abundante. 
Swain observou que a interação entre os alunos ocorria principalmente na LM, não na língua alvo. E, além disso, observou que na sala de aula de imersão, como também acontece na sala de aula de L2 (LONG, 1983) e de LE (ALMEIDA FILHO; BARBIRATO, 2000), havia poucas oportunidades de interação entre pares com negociação de significado, em que o falante parafraseia o que foi dito, explicando o que quer dizer, tornando o insumo mais simples e mais compreensível. Quando há ausência dessa interação, a aquisição é limitada, como atesta a Hipótese da Interação (LONG, 1981, 1983), o que de fato foi verificado por Swain (1985) no desempenho dos alunos em relação à aquisição gramatical.

Assim, o input compreensível não poderia ser a única variável causativa na aquisição da estrutura, como afirma Krashen (1981). Os resultados da pesquisa de Swain (1985) mostram que o tipo de input compreensível é um fator determinante que contribui diferentemente para a aquisição de L2, dependendo de sua natureza e do aspecto da língua: o input compreensível não interacional contribui para a aquisição de traços da competência discursiva (como coerência e coesão) e sociolinguística (como o uso de expressões formulaicas e o emprego do marcador discursivo tu), enquanto o input compreensível interacional contribuiria para a aquisição da forma: "a negociação do significado, levando a um consenso comunicativo, é um primeiro passo necessário para a aquisição gramatical.” A mensagem compreendida permitirá, assim, que o aprendiz observe a forma.

Swain propõe, então, novos papéis para o output. Além de gerar input compreensível, ao oferecer oportunidades para o aprendiz testar hipóteses, experimentar meios de se expressar e verificar se funcionam, o output oferece oportunidades para o uso significativo dos recursos linguísticos de que se dispõe e leva o aprendiz a se mover do processamento semântico para o sintático.

Portanto, afirma a autora, é possível compreender o input sem analisá-lo sintaticamente. Por isso os alunos em imersão não adquiriram os traços gramaticais e sociolinguísticos que dependem de conhecimento gramatical: faltaram-lhes oportunidades de interação oral para se expressarem (output) e, consequentemente, receber input negativo, ou seja, receber o retorno do interlocutor, mostrando que a produção do aprendiz não havia sido bem sucedida de alguma maneira, através de correções explícitas, pedidos de confirmação ou esclarecimento.

E assim, a interação mostra-se essencial para que o aprendiz possa desenvolver suas competências na LA, e pode-se perceber que tanto a aquisição quanto a aprendizagem se realizam também na comunicação. 


\subsection{Ensino Comunicativo: o ensino de línguas para a comunicação}

Comunicação, segundo Larsen-Freeman (2000), é um processo no qual o conhecimento das formas linguísticas, significados e funções é necessário, mas não é suficiente. Para se comunicar com êxito, também é preciso saber que uma mesma forma pode ter vários significados e funções e que uma única função pode ser expressa por formas diversas. Portanto, é essencial saber escolhê-las apropriadamente, de acordo com cada contexto social e com o papel dos falantes, bem como ser capaz de negociar significado com seus interlocutores. O objetivo do Ensino Comunicativo é habilitar o aprendiz para se comunicar na língua-alvo, então os aspectos culturais devem igualmente ser levados em consideração - como no italiano o uso do pronome Lei, em situações formais ou de pouca intimidade, e $t u$, em situações informais entre amigos e familiares.

O Ensino Comunicativo tem currículo nocional-funcional: o eixo central de suas atividades são noções comunicativas, como tempo, frequência, quantidade, localização e funções comunicativas, como cumprimentar, sugerir, pedir, perguntar (RICHARDS; RODGERS, 2001).

Larsen-Freeman (2009) cita três características comuns a atividades verdadeiramente comunicativas: lacuna de informação, escolha e retorno ${ }^{21}$ - características também presentes na comunicação real entre duas ou mais pessoas.

Quando se fazem perguntas ao interlocutor, que responde com uma informação da qual não se tinha conhecimento, ou mesmo quando o interlocutor responde a uma pergunta dando sua opinião a respeito de um tema, estes são exemplos de lacuna de informação (information gap) em que um dos participantes apresenta alguma informação que outros não tinham. Essa lacuna traz mais naturalidade e autenticidade às atividades ou tarefas em sala de aula (RICHARDS; SCHMIDT, 2013).

Nas atividades comunicativas, os aprendizes escolhem o que irão dizer e como irão dizer. Essa escolha (choice) aproxima a atividade em sala de uma oportunidade real de comunicação, em que não se espera do professor um controle rígido da participação do aluno. Larsen-Freeman afirma: "Se o exercício é estritamente controlado de maneira que os alunos

\footnotetext{
${ }^{21}$ Information gap, choice, feedback são termos de Morrow (1981) - In JONHSON, K.; MORROW, K. (eds.). Communication in the classroom. Essex: Longman, 1981. (Apud LARSEN-FREEMAN, 2000, p. 129)
} 
possam apenas dizer uma coisa de uma única maneira, o falante não tem escolha, e a troca, portanto, não é comunicativa." ${ }^{22}$ (2000, p. 129).

$\mathrm{Na}$ comunicação os interlocutores podem confirmar se compreenderam e se foram compreendidos. A terceira característica das atividades comunicativas é o retorno (feedback) que o ouvinte dá ao falante, indicando se os seus propósitos foram alcançados na comunicação: "Se o ouvinte não tem uma oportunidade de dar esse retorno ao falante, então a troca não é verdadeiramente comunicativa."23 (2000, p. 129).

Dentro desse contexto, surge o Ensino por Tarefas, que também tem a comunicação como eixo central, mas seu foco é “[...] ensinar a língua através da comunicação e não para ela." ${ }^{24}$ (2000, p. 137 - grifo nosso).

\subsection{Ensino por Tarefas: o ensino de línguas através da comunicação}

No Ensino por Tarefas, o currículo não se organiza em termos de noções ou funções, mas de tarefas (tasks) que, segundo Long (2015), são as coisas que as pessoas fazem no seu dia a dia, como participar de uma reunião, assistir à televisão ou pegar um livro emprestado na biblioteca. Na realização de uma única tarefa podem ser empregadas várias funções comunicativas: para a tarefa fazer compra na feira, por exemplo, são empregadas funções como cumprimentar, pedir, perguntar, agradecer. Na abordagem proposta por Long (2015), as tarefas reais são identificadas através de levantamento e análise das necessidades dos alunos (needs analysis) e, então, transformadas em tarefas pedagógicas, elaboradas pelo professor, que são realizadas pelos aprendizes em sala de aula.

As tarefas podem, segundo Ellis (2003), ser elaboradas para induzir o uso de algum item linguístico específico (focused tasks) ou não. Nas tarefas não focadas (unfocused tasks), os temas são trazidos da vida real dos aprendizes e podem predispor a escolha de certas formas linguísticas, mas não são desenhadas com esse fim. O objetivo de ambos os tipos de tarefas, focadas e não focadas, é estimular o uso comunicativo da língua. Há ainda aquelas elaboradas para trazer a atenção dos alunos para determinada questão linguística, em que os alunos conversam sobre os dados apresentados, as chamadas tarefas de ampliação de consciência (consciousness raising tasks).

\footnotetext{
22 "If the exercise is tightly controlled so that students can only say something in one way, the speaker has no choice and the exchange, therefore, is not communicative."

23 "If the listener does not have an opportunity to provide the speaker with such feedback, then the exchange is not really communicative."

24 “[...] teaching through communication rather than for it.”
} 
Dentre várias propostas de Ensino por Tarefas ${ }^{25}$, como as de Ellis $(2003,2020)$, Nunan (1989), Willis (1996) e J. Willis e D. Willis (2007), destacamos aquela descrita por Long (2015) em Second Language Acquisition and Task-Based Language Teaching ${ }^{26}$. O autor compara diversas abordagens do ensino de segunda língua (L2) e identifica dois tipos: sintéticas e analíticas. A partir dessa distinção, propõe o Ensino de Línguas Baseado em Tarefas (TBLT), e o distingue do ensino apoiado em tarefas (task-supported) e do ensino por tarefas de currículo procedural (task-based), por terem a tarefa como um meio de se praticar itens linguísticos e não como um fim em si mesmo: "um verdadeiro curso do TBLT, por outro lado, requer um investimento de recursos em análise de necessidades e produção de materiais apropriados para uma população específica de aprendizes." ${ }^{27}$ (LONG, 2015, p. 3).

\subsection{Abordagens Sintéticas e Analíticas no Ensino de Línguas}

Long (2015) distingue duas posições entre as quais o ensino de línguas tem oscilado historicamente: intervencionista, que evidencia o estudo da forma e do código linguístico, e não intervencionista, que focaliza o significado e o uso da língua, as quais são apresentadas a seguir.

\subsubsection{Abordagens Sintéticas}

Abordagens intervencionistas também são chamadas sintéticas ${ }^{28}$, pois nelas o papel do aluno é sintetizar os itens apresentados para propósitos comunicativos (LONG, 2015). Sob a influência da linguística estrutural e da psicologia comportamental (neobehaviorista), a língua é considerada um comportamento verbal e a aprendizagem de línguas é vista como um sistema mecânico de formação de hábitos em que o aluno é induzido a se comportar de determinada maneira e os novos hábitos são fortalecidos através do reforço das respostas corretas (PAULSTON, 1971).

\footnotetext{
${ }^{25}$ Ver Anexo 1 e Anexo 2.

${ }^{26}$ Aquisição de Segunda Língua e Ensino de Línguas Baseado em Tarefas, ainda sem tradução para o português.

27 "A true TBLT course, conversely, requires an investment of resources in a needs analysis and production of materials appropriate for a particular population of learners."

${ }^{28} \mathrm{O}$ ensino de línguas que envolve uma combinação de currículo, materiais didáticos, metodologia, pedagogia e testes sintéticos, cujos conteúdo e foco das aulas, bem como a avaliação do sucesso (achievement) do aluno, são as próprias formas, Long (2015) se refere a ele como foco nas formas (focus on forms). São considerados sintéticos, com foco nas formas, a abordagem Aural-Oral e os métodos Gramática-Tradução e Audiolingual, por exemplo.
} 
A instrução é explícita, de interface forte ${ }^{29}$, e o ensino de formas e estruturas é central. O conteúdo programático (de currículo lexical, gramatical, nocional ou funcional) é preestabelecido e sequenciado gradualmente, de acordo com a complexidade dos elementos que serão ensinados. Pequenas unidades linguísticas são apresentadas através de diálogos ou textos elaborados para esse fim, e praticadas uma de cada vez pelos alunos, através de exercícios escritos e de treino escrito ou oral (repetições de frases com simples alterações ou variações do modelo original apresentado, conhecidas como pattern drills ou drills ${ }^{30}$ ). Tarefas são empregadas, raramente, apenas como extensão da prática do item linguístico em foco naquela lição. A unidade linguística seguinte é introduzida apenas após a correção de eventuais erros. Acertando, ou seja, repetindo da maneira adequada, ou esperada, os alunos recebem um estímulo positivo, denominado reforço. Errando, a correção é feita através de feedback negativo, com simples repetição da forma esperada, considerada correta. O professor, portanto, tem papel central, cabendo a ele apresentar as formas corretas, conduzir a prática e corrigir os erros dos alunos.

Nas abordagens intervencionistas, como a Aural-Oral, a língua-alvo (LA) é o objeto de instrução e considera-se que a aprendizagem se dá através da proceduralização do conhecimento declarativo (o quê) e da automatização do conhecimento procedural (como), ou seja, um processo através do qual o conhecimento explícito seria automatizado através da prática intensiva, transformando-se em conhecimento implícito.

Materiais didáticos sintéticos, como o In Italiano (CHIUCHIU, MINCIARELLI e SILVESTRINI, 1985), são baseados em gramática e considerados universais, no sentido de servirem a todos os alunos, independentemente de suas necessidades e objetivos individuais. Alguns são produzidos na língua materna que, em muitos casos, também é usada preferencialmente na sala de aula. São linguisticamente controlados e mecânicos ${ }^{31}$ e, por

\footnotetext{
${ }^{29}$ Interface é a relação entre aprendizagem implícita e explícita no ensino de línguas. O ensino ou as abordagens que se caracterizam por instrução e aprendizagem explícita são conhecidos pela posição de interface forte (strong interface position), a qual defende que o conhecimento explícito pode ser transformado em conhecimento implícito através da prática (RICHARDS; SCHIMIDT, 2013).

${ }^{30}$ Pauliston (1971) define três tipos de drills: mecânico, para simples memorização da estrutura, sem análise gramatical ou sem a necessidade de compreender o significado, com uma única resposta correta possível, adequado para a prática em coro; significativo, onde mais de uma resposta é possível, sendo mais indicado para a prática de vocabulário, em que o objetivo é uma resposta gramatical correta através da manipulação da forma; comunicativo, em que o aluno tem a oportunidade de expressar opiniões pessoais, geralmente respondendo à perguntas feitas pelo professor ou um colega, valendo-se de estrutura e vocabulário praticados e memorizados nos drills anteriores.

31 Há também métodos sintéticos de estudo autônomo, como o Plimsleurß (Disponível em: $<$ https://www.pimsleur.com>. Acesso em 15 mai. 20.), que consiste na prática de drills mecânicos orais e escritos, em que o aprendiz ouve explicações e instruções na LM, em um aplicativo para telefone celular ou tablet, atualmente também integrado com dispositivos de inteligência artificial que funcionam por comando de voz. O próprio aplicativo oferece o feedback negativo dos drills escritos, mas o aprendiz não recebe um feedback
} 
apresentarem um item linguístico por vez, podem ser usados com facilidade por professores que ainda não tenham um bom conhecimento ou domínio da LA, pois possibilitam ao professor estar um passo à frente de seus alunos, preparando-se com o estudo da unidade linguística que será apresentada na lição seguinte.

\subsubsection{Abordagens Analíticas}

Abordagens não-intervencionistas também são chamadas analíticas ${ }^{32}$, pois o papel do aluno é analisar o input $^{33}$ e induzir as regras de gramática e seu uso (LONG, 2015). Sob a influência da linguística nativista, Chomskyana, a língua é considerada uma habilidade inata, numa visão em que "[...] o conhecimento humano se desenvolve a partir de estruturas, processos e 'ideias' que estão na mente desde o nascimento [...], sendo responsáveis pela estrutura básica da língua e pela maneira como ela é aprendida."34 (RICHARDS; SCHIMIDT, 2013, p. 285).

A instrução é implícita, de interface zero ${ }^{35}$, e o ensino de formas e estruturas, se presente, é secundário. A aquisição se dá através da interação significativa entre falantes, na comunicação natural em que o foco não é a forma gramatical, mas as mensagens que estão sendo transmitidas e compreendidas. A correção de erros não tem tanto destaque, mas sim a negociação de significado, em que os enunciados são modificados para facilitar ou clarear a compreensão do que está sendo dito. O papel do professor é apresentar aos alunos amostras autênticas e compreensíveis da língua-alvo e oferecer oportunidades de comunicação na LA.

Nas abordagens não-intervencionistas, como a Abordagem Comunicativa, a LA é o meio de instrução, e considera-se que a aquisição se dá através do próprio uso da língua

\footnotetext{
da sua prática oral: pode apenas ouvir o que seria a resposta correta ou esperada em cada caso e, se não conseguir perceber por si mesmo as diferenças entre sua produção e o modelo, é sujeito a fossilizar um modo de comunicação incompreensível para os falantes da LA.

$32 \mathrm{O}$ ensino de línguas que envolve uma combinação de currículo, materiais didáticos, metodologia e pedagogia analíticos, cujos conteúdo e foco das aulas são a mensagem, o assunto em questão e a comunicação, Long (2015) se refere a ele como foco no significado (focus on meaning). São considerados analíticos, com foco no significado, a Abordagem Natural (KRASHEN; TERELL, 1983), os programas de educação de imersão e os cursos de currículo procedural, no qual o processo de aquisição é conduzido pela realização de tarefas comunicativas através da negociação do significado, ao invés do ensino explícito e prática de formas gramaticais (RICHARDS; SCHIMIDT, 2013).

33 "No aprendizado de línguas, conjunto de dados que o indivíduo recebe ao ouvir a língua sendo usada ao seu redor." (HOUAISS, [201-])

34 “"...] human knowledge develops from structures, processes, and 'ideas' which are in the mind at birth [...], and that these are responsible for the basic structure of language and how it is learned."

${ }^{35}$ Interface é a relação entre aprendizagem implícita e explícita no ensino de línguas. O ensino ou as abordagens que se caracterizam por aprendizagem implícita são conhecidos pela posição de interface zero (no-interface position), a qual defende que conhecimento implícito e explícito são sistemas distintos e independentes, de modo que, um não promove mudanças no outro (RICHARDS; SCHMIDT, 2013).
} 
(como na aquisição da LM) e que adultos mantém a capacidade de adquirir línguas incidentalmente, a mesma de quando eram crianças. Entende-se que conhecimento explícito não se transforma em conhecimento implícito: são processos e sistemas distintos, localizados em regiões distintas do cérebro. Somente quando tem tempo suficiente, e foco na língua como objeto, o aprendiz pode utilizar seu conhecimento explícito para monitorar e editar a própria produção.

Materiais didáticos analíticos não seguem uma sequência gramatical (não há um currículo linguístico, nem implícito nem explícito), mas são desenvolvidos a partir de atividades e textos orais ou escritos genuínos (ou, originalmente, elaborados para comunicação entre falantes nativos e, então, modificados para aprendizes da língua) escolhidos pelo conteúdo, interesse e grau de compreensão. A língua usada na aula é preferencialmente (ou exclusivamente) a LA, e a linguagem é significativa ou comunicativa, raramente mecânica, já que as atividades não priorizam a prática de estruturas ou formas, mas a compreensão de textos e a interação entre os participantes. (LONG, 2015)

\subsubsection{Fragilidades das Abordagens Sintéticas e Analíticas}

Abordagens Sintéticas, com foco nas formas, apresentam certas fragilidades, apontadas por Long (2015). Primeiramente, poucas são as formas que podem ser ensinadas isoladamente pelo simples fato de que elas naturalmente se inter-relacionam. A instrução explícita de estruturas específicas pode ser útil, resultando em aprendizado verificável em testes, mas leva mais tempo do que normalmente se tem disponível nos cursos de língua. Mesmo a aprendizagem de regras gramaticais mais simples não se dá prontamente, pela simples repetição para sua memorização, mas são o resultado de um processo que revela uma “[...] gradual extensão da regra consensual, de uma estrutura para outra, numa sequência governada pela complexidade das estruturas, conforme se avalia pela sua marcação."36 (LONG, 2015, p. 23).

Durante a aquisição, notam-se erros comuns, emprego de formas que não foram ensinadas em sala de aula e que não ocorrem na língua-alvo, mostrando que a aprendizagem não se dá simplesmente por acréscimo de uma unidade linguística por vez, mas é um processo criativo e ativo, que foge ao controle que se poderia esperar do professor. Os aprendizes são os agentes ativos e criativos desse processo, mas abordagens sintéticas, com foco nas formas,

36 " $[\ldots .$.$] gradual extension of the agreement rule from one structure to another, the sequence governed by the$ structures' complexity, as judged by their markedness." 
centram o processo de aprendizagem no professor, em métodos mecânicos e engessados, deixando pouca abertura para o florescimento e ação dessa espontaneidade e criatividade naturais. (LONG, 2015).

As interlínguas ${ }^{37}$ (ILs) apresentam padrões e estágios de desenvolvimento semelhantes, e sua precisão e sequências de desenvolvimento são as mesmas, tanto para aprendizes que recebem algum tipo de instrução quanto para aqueles que adquirem a língua de maneira naturalística. Assim, independentemente da ordem em que as estruturas sejam introduzidas uma a uma nos materiais sintéticos, a aquisição seguirá uma sequência de desenvolvimento própria e, para que seja bem-sucedida, é necessário levar-se em consideração esse currículo interno do aprendiz. "Enquanto ILs são caracterizadas por variação sistemática e livre, e duas ILs não sejam exatamente idênticas, as impressionantes semelhanças observadas sugerem que poderosos processos universais de aprendizagem estejam atuando, como nas línguas maternas." ${ }^{38}$ (LONG, 2015, p. 22).

O desenvolvimento da IL não é linear e, por vezes, os aprendizes progridem numa área, mas regridem noutra. Sua atenção está geralmente voltada para o aspecto novo, que está sendo estudado naquele momento. E em um universo em que a sintaxe torna-se cada vez mais complexa, aumentando a quantidade de elementos que os aprendizes precisam observar, cresce também a demanda da sua capacidade de processamento, diminuindo os recursos de atenção disponíveis para outros elementos que ele já havia demonstrado ter adquirido. (LONG, 2015).

Os currículos sintéticos, com foco nas formas, não levam em consideração o fato de, em uma mesma sala de aula, os alunos se encontrarem em diferentes estágios de desenvolvimento, mesmo tendo resultados semelhantes em testes de proficiência ou de nivelamento. E por se basearem em um currículo preestabelecido, as abordagens sintéticas não levam em consideração as necessidades individuais, ensinando conteúdos e desenvolvendo habilidades que talvez não sejam de interesse dos alunos, estendendo a duração dos cursos e tornando-os menos eficientes. (LONG, 2015).

Abordagens analíticas, com foco no significado, por sua vez, apresentam outras questões (LONG, 2015). Primeiramente o fato de considerar que os adultos mantêm a mesma capacidade de aprender línguas incidentalmente de quando eram crianças. Porém “[...] o que pode ser adquirido implicitamente a partir de contextos comunicativos é tipicamente bem

\footnotetext{
${ }^{37}$ Sistema linguístico aproximativo no qual a produção linguística do aprendiz revela tanto características da LM quanto da LA (SELINKER, 1972).

38 "While ILs are characterized by systematic and free variation, and no two ILs are exactly alike, the striking commonalities observed suggest powerful universal learning processes are at work, as in L1A."
} 
limitado em comparação com normas do falante nativo, e a realização da precisão da L2 por adultos geralmente requer recursos adicionais de aprendizagem explícita." 39 (N. ELLIS, 2008a, p. 1)

Além disso, o aprendizado incidental demanda um tempo longo, pois traços menos salientes da língua (que ocorrem com menor frequência, por exemplo) demoram a ser percebidos, ou não são percebidos até que a atenção do aprendiz seja dirigida para aquele traço. Nesse sentido, Schmidt (1990, p.149) afirma que “[...] a aprendizagem incidental é certamente possível quando a tarefa demanda o foco da atenção em traços relevantes do input." 40

Do mesmo modo, estruturas características da língua materna que sejam agramaticais na língua-alvo podem passar desapercebidas se a comunicação não for comprometida, sendo necessário feedback negativo para que o aprendiz perceba a diferença. E, finalmente, uma instrução mais variada (implícita, explícita, foco na forma, foco no significado) pode atender melhor à cultura de aprender de cada aluno.

Assim, Long (2015) propõe um terceiro tipo de abordagem, analítica com foco na forma $^{41}$, que o autor denomina Ensino de Línguas Baseado em Tarefas (Task-Based Language Teaching, TBLT) e diferencia de outras formas de Ensino por Tarefas. O autor faz uma crítica a programas híbridos, que denomina programas linguísticos apoiados em tarefas (tasksupported), por não terem as tarefas como um fim em si mesmo, mas apenas como um meio de se praticarem estruturas gramaticais e vocabulário. Nesse caso, tratar-se-iam de programas sintéticos, também conhecidos como construção de habilidades, que consideram que adultos não seriam capazes de aprender línguas incidentalmente, apenas por instrução explícita.

Um programa de tarefas genuíno (task-based), para Long, deve ser analítico:

\footnotetext{
'Tarefa' é a unidade de análise que permeia a elaboração, a implementação e a avaliação de um programa de Ensino de Línguas Baseado em Tarefas (TBLT), incluindo a maneira como os resultados do aluno são avaliados - por testes de desempenho baseados em tarefa. TBLT é uma abordagem analítica com foco na forma. $^{42}$ (LONG, 2015, p.3)
}

\footnotetext{
39 " $[. .$.$] what can be acquired implicitly from communicative contexts is typically quite limited in comparison to$ native speaker norms, and adult attainment of L2 accuracy usually requires additional resources of explicit learning."

40 “....] incidental learning is certainly possible when task demands focus attention on relevant features of the input."

${ }^{41}$ Distintamente das abordagens sintéticas, em que as formas são o foco central das aulas, Long (2015) propõe que a atenção seja voltada à forma apenas momentaneamente e que se limite àquela que emerja do uso da línguaalvo durante a realização das tarefas pedagógicas (ver sessão 1.5.1.6 Foco na forma).

42 “' 'Task' is the unit of analysis throughout the design, implementation, and evaluation of a TBLT program, including the way student achievement is assessed - by task-based, criterion-referenced performance tests. TBLT is an analytic approach, with a focus on form."
} 


\subsection{Abordagem Analítica com foco na forma: o Ensino de Línguas Baseado em Tarefas}

O Ensino de Línguas Baseado em Tarefas como definido por Long ${ }^{43}$, é "uma abordagem de elaboração, implementação e avaliação de cursos, que visa atender as necessidades comunicativas de grupos diversos de aprendizes, procurando satisfazer todos os sete critérios" ${ }^{44}$ fundamentais: ter relevância, ser baseado em princípios de psicolinguística e de filosofia da educação, ter responsabilidade de recursos, ser centrado no aprendiz, evitar problemas já conhecidos e ter funcionalidade (LONG, 2015, p.3).

Long (2015) afirma que, para garantir sua relevância, o ensino de línguas deve começar com uma análise de necessidades das tarefas que os aprendizes pretendem realizar na língua-alvo como, por exemplo, ler notícias, almoçar com um colega, assistir à TV e fazer compras. Essas tarefas reais, do dia a dia, são transformadas em tarefas pedagógicas (atividades e materiais com que professores e alunos trabalham na sala de aula) e compõem o conteúdo programático do curso - que consiste em uma série de tarefas pedagógicas cada vez mais complexas.

O autor destaca a importância de se ir além das variáveis afetivas, considerando também as variáveis cognitivas envolvidas na aquisição ou aprendizagem. Desse modo, o ensino de línguas deve se basear, primeiramente, em princípios da psicolinguística, sendo condizente com teorias de aquisição de L2, levando em consideração as características da aprendizagem em cada faixa etária, como as pessoas aprendem e fazem uso dessas línguas, a relação entre conhecimento implícito, explícito e a efetividade deste em relação ao trato de limitações e à construção da aprendizagem. Deve também se basear em princípios da filosofia da educação como l'éducation integral e o "aprender fazendo", liberdade individual, racionalidade, emancipação, centralidade no aprendiz, relações igualitárias entre professor e alunos, democracia participativa, auxílio mútuo e cooperação.

Para Long (2015), o investimento de tempo e de recursos financeiros deve ser tratado com responsabilidade, no sentido da elaboração e produção de material didático eficiente que aborde temas mais relevantes para os aprendizes. $\mathrm{O}$ autor considera que materiais publicados por grandes editoras internacionais, que atingem um grande número de alunos em todo o

\footnotetext{
43 As primeiras ideias de Long a respeito do Ensino de Línguas Baseado em Tarefas foram desenvolvidas nos anos de 1980-1982 e apresentadas pela primeira vez em 1983, em uma comunicação que foi publicada em artigo no ano de 1985 - informações que constam no site da Universidade Maryland, onde ele é professor (Disponível em: <https://sllc.umd.edu/sla/mlong $>$. Acesso em: 17/11/19). Em 2015, Long publicou Second Language Aquisition and Task Based Language Teaching, seu livro mais recente a respeito do tema.

44 "Task-Based Language Teaching (TBLT), an approach to course design, implementation, and evaluation intended to meet the communicative needs of diverse groups of learners and which attempts to satisfy all seven criteria."
} 
mundo, mostram-se dispendiosos, genéricos e longos demais, estendendo excessivamente a duração dos cursos. Ele nota também que apenas um pequeno percentual dos alunos iniciantes chega aos níveis avançados dos cursos de língua e sugere que um currículo mais essencial e relevante possa estimular os alunos a realizar o curso completo, atingindo um nível mais avançado de proficiência da língua-alvo em um tempo mais razoável.

O ensino de línguas deve ainda, segundo o autor, evitar problemas conhecidos de abordagens existentes, como ter essencialmente foco na forma ou, em outro extremo, foco no significado. Abordagens sintéticas, tendo o foco na forma, priorizam o estudo das estruturas gramaticais, negligenciando o desenvolvimento da expressão oral e da interação. Por outro lado, abordagens analíticas, com foco no significado, mostram-se ineficientes no tratamento de erros recorrentes. Nesse sentido, com o Ensino de Línguas Baseado em Tarefas, Long propõe uma abordagem mista, um caminho do meio, empregando um conteúdo programático analítico baseado em tarefas e, ao mesmo tempo, dando atenção a elementos linguísticos que surjam durante a realização das mesmas, oferecendo oportunidades de aprendizagem intencional para facilitar e acelerar o processo de aprendizagem, compensando a menor capacidade de aprendizagem incidental dos adultos.

Aquisição, ou aprendizagem incidental, é aquela que se dá de maneira espontânea, "desintencional”, quando o foco da atenção não está na aprendizagem em si. As crianças adquirem a L1 incidentalmente, na interação com outros falantes, em ambiente de simples exposição à língua materna e de comunicação natural, espontânea e significativa. Dessa experiência de uso, adquire-se um conhecimento complexo da estrutura da língua, implícito, cujas regras não se sabe descrever, mas se usa automaticamente ${ }^{45}$.

Mayberry e Lock (2003, p.382) sugerem que durante a primeira infância há "uma janela de tempo delimitado" durante a qual a estimulação linguística do ambiente juntamente com o desenvolvimento neural e do córtex cerebral criam a capacidade de aprender línguas. Há certo consenso na comunidade científica de que de 0 a 6 anos a aquisição de L2 também é bem-sucedida, incidental e implícita, sendo comuns a todos as mesmas ordens de desenvolvimento ${ }^{46}$ (LONG, 2015).

\footnotetext{
45 São exemplos de conhecimento implícito na L1: as sequências de sons possíveis na língua e as expressões idiomáticas, como no português "tomar banho" (e não "fazer banho") e no italiano "fare la doccia" (e não "prendere la doccia").

${ }^{46}$ Crianças que, por alguma razão, inicialmente não tiveram acesso suficiente ao input da L1 podem recuperar essa defasagem e alcançar os mesmos níveis de desenvolvimento de crianças da mesma faixa etária ao ter contato e interação com elas. A aquisição de L1 por crianças é mais uniformemente bem-sucedida do que por adultos. Embora as condições socioeconômicas dos pais e seu estilo de interação com os filhos possa afetar o nível de proficiência que crianças atingem entre 5-6 anos (como o tamanho do vocabulário), fatores como QI e
} 
Em um ambiente de simples exposição à L2 e de comunicação nessa língua, crianças podem chegar a desenvolver habilidades linguísticas semelhantes às de falantes nativos da mesma faixa etária. Mas essa janela apresentaria períodos sensíveis que terminariam aos 4 ou 6 anos para a aquisição de fonologia (chegando até os 12 anos em alguns casos), aos 6 ou 10 anos para aquisição de léxico e expressões idiomáticas e, em meados da adolescência, para aquisição de morfologia e sintaxe $\mathrm{e}^{47}$.

Após esses períodos sensíveis, os aprendizes teriam, então, certas limitações para a aquisição de línguas. No que se diz respeito aos sons da L2, por exemplo, Cutler (2001) observa um déficit tanto de produção quanto de percepção, devido à perda da flexibilidade de percepção de contrastes fonéticos característica dos primeiros anos de vida: “Ouvintes adultos simplesmente não podem diferenciar contrastes não nativos tão eficientemente quanto contrastes nativos." ${ }^{48}$ (p.3)

A capacidade de aprendizagem implícita, sem a consciência do que está sendo aprendido, diminui após os 12 anos de idade (JANACSEK, FISER \& NEMETH, 2012). O aprendiz percebe a L2 pelo filtro da L1: há uma forte tendência de se transferir os parâmetros que são significativos na língua materna (fonológicos, lexicais, estruturais) para a língua-alvo e de não identificar parâmetros significativos na L2 como, por exemplo, a dificuldade de um aprendiz brasileiro em notar a dupla consoante no italiano e pronunciá-la diferentemente da consoante simples, como em notte (noite) e note (notas).

Nesse caso, o papel do professor, de oferecer aos aprendizes os contextos para a aquisição e a oportunidade de interação na língua-alvo, é ampliado: ele atua como um instrumento de aumento da percepção do aluno, conduzindo o foco da atenção para aqueles aspectos que o aprendiz não é capaz de distinguir, viabilizando a percepção, a produção e a aquisição da L2.

A aquisição puramente incidental de vocabulário continua possível na idade adulta, mas em ritmo mais lento e em um prazo mais longo (a de gramática também, mas esta mostra-se ainda menos eficiente). Ainda que tal característica possa ser justificada por fatores como atitude, motivação, aptidão, tempo de exposição e oportunidades de uso da língua, a aquisição puramente incidental por adultos requer mais tempo do que o tempo que geralmente

ambiente têm efeitos menores e temporários no desenvolvimento linguístico sendo, geralmente, mais ligados à velocidade da aprendizagem do que ao resultado final alcançado (LONG, 2015).

${ }^{47}$ Segundo a Hipótese de Enriquecimento Neurofisiológico (LONG, 2007c), a exposição a duas ou mais línguas durante os períodos sensíveis de aquisição levaria a um aumento consistente e duradouro do potencial de aquisição de línguas: o estímulo do input bilíngue ou multilíngue, mais rico e variado, na infância e, em meados da adolescência, poderiam favorecer a formação de redes neurais mais complexas e numerosas, que facilitariam a criação de novas sinapses também na idade adulta, contribuindo, assim, para a aquisição de novas línguas.

48 "Adult listeners simply cannot discriminate nonnative contrasts as efficiently as native contrasts." 
se tem à disposição, tornando-a inviável. Porém, trabalhando com tarefas pedagógicas, a aquisição incidental pode ser facilitada. (LONG, 2015)

O Ensino de Línguas Baseado em Tarefas, como proposto por Long, é, portanto, uma abordagem centrada no aluno, uma vez que o conteúdo das aulas é baseado em suas necessidades e objetivos específicos, respeitando-se as diferenças individuais dos aprendizes. E tem a funcionalidade como característica primordial, buscando ser relevante e eficaz, na medida em que vai de encontro aos objetivos de cada aluno e favorece a aquisição da língua com oportunidades reais de comunicação e feedback corretivo, levando os aprendizes ao desenvolvimento de suas habilidades na língua-alvo, através da interação e para aprimorá-la.

Long distingue três eixos próprios do ensino de línguas: Princípios Metodológicos, Princípios Pedagógicos e Critérios de Avaliação ${ }^{49}$.

\subsubsection{Princípios Metodológicos}

Os Princípios Metodológicos são características desejáveis no design instrucional (planejamento e elaboração de cursos e materiais didáticos) motivadas por teorias e pesquisas em aquisição de língua não materna, psicolinguística e filosofia da educação, as quais demonstram que tais princípios são necessários para a aquisição ou são facilitadores dela, tornando-a mais eficiente. Essa motivação teórica com respaldo empírico, segundo o autor, é o que qualifica esses dez Princípios Metodológicos para qualquer abordagem de ensino de línguas, o que evidencia seu caráter universal ${ }^{50}$ : (1) usar tarefas, não textos, como unidades de análise; (2) promover a aprendizagem fazendo; (3) elaborar o input; (4) prover input rico; (5) encorajar a aprendizagem indutiva de chunks ou parcelas; (6) foco na forma; (7) prover feedback negativo; (8) respeitar os currículos internos e os processos de desenvolvimento do aluno; (9) promover a aprendizagem colaborativa cooperativa; (10) individualizar a instrução.

\subsubsection{Usar tarefas, não textos, como unidades de análise}

As tarefas são o cor, a essência do Ensino Baseado em Tarefas, constituindo o eixo central do programa do curso sobre o qual as aulas se desenvolvem. Através delas os alunos

\footnotetext{
${ }^{49}$ Motivação teórica, suporte empírico, argumentação lógica e consistência com teorias aceitas em outras áreas são os critérios através dos quais a validade dos procedimentos pedagógicos pode ser avaliada. (LONG 2015) ${ }^{50}$ Três Princípios Metodológicos têm sua origem no Ensino de Línguas Baseado em Tarefas de Long: usar tarefas, não textos, como unidade de análise; elaborar input; foco na forma. Os demais se encontram em várias abordagens, sendo que alguns, como dar feedback negativo, estão presentes em todas. (LONG, 2015)
} 
vivenciam a língua-alvo para praticar e realizar aquilo com que irão se deparar além da sala de aula.

De acordo com Long (2015, p.303) "textos são registros congelados, frequentemente irreais, de tarefas realizadas por outrem." ${ }^{51}$ Nesse sentido, a leitura de textos ou transcrições de diálogos, genuínos ou simplificados, traduziria a noção de língua como objeto, e não como entidade viva. Por isso textos não deveriam ser usados como unidade de análise, na visão do autor.

Entretanto, textos podem ser usados como introdução de um tema relevante para o aprendiz, e a conversa realizada a partir da leitura pode ser colocada como uma oportunidade de comunicação real, em que o aprendiz expresse suas ideias, sentimentos, compreensões e opiniões. E nesse sentido, a conversa a partir de um texto produzido por outrem pode ser vista como uma tarefa pedagógica genuína, em que o professor é o moderador que estimula o diálogo com ou entre os alunos, através de perguntas que podem ir além de uma simples interpretação de texto.

\subsubsection{Promover o aprendizado fazendo}

Ao realizar tarefas pedagógicas cada vez mais complexas, o aprendiz tem a oportunidade de desenvolver, gradativamente, suas habilidades linguísticas através do próprio uso da língua. Os problemas ou dificuldades linguísticas são tratados na sequência em que vão surgindo, segundo as necessidades que se apresentam e não a partir de um currículo gramatical ou lexical pré-estabelecido.

O foco do aprendiz se dirige para a ação: a língua não é o objeto de sua atenção, mas o meio para se realizar o que a tarefa pedagógica propõe, criando as condições favoráveis para a aquisição incidental e implícita: “[...] a aprendizagem da gramática se desenvolve a partir do uso da língua, não o contrário." ${ }^{52}$ (LONG 2015, p.221)

\subsubsection{Elaborar o input}

Materiais sintéticos apresentam input simplificado, textos orais ou escritos produzidos especificamente para fins de aprendizagem, limitando-o aos itens linguísticos que já tenham sido vistos anteriormente, acrescidos dos novos itens introduzidos a cada lição ou, ainda,

51 "Texts are frozen records, often unrealistic records, of task accomplishment by others."

52 "[...] learning grammar evolves out of language use, not the way around." 
textos genuínos que foram alterados para atender as delimitações do programa do curso, através da redução do vocabulário e das estruturas gramaticais originais. Esse cuidado em se conduzir a aprendizagem passo a passo, frequentemente, impede o contato com a realidade da língua, ao apresentar input que se mostra artificial, muito distante da maneira como os falantes nativos verdadeiramente se comunicam.

Materiais analíticos, por sua vez, priorizam textos orais ou escritos produzidos para comunicação entre falantes nativos. Esse input genuíno, útil e adequado para aprendizes avançados é, muitas vezes, de difícil compreensão para aprendizes iniciantes, mostrando-se pouco favorável à aquisição da língua nos primeiros estágios dos cursos.

Para torná-lo mais compreensível, condição necessária para a aquisição (KRASHEN 1985), a proposta de Long (2015) é elaborar o input através dos mesmos recursos usados por falantes nativos para a negociação de significado nas interações com falantes não nativos. Exemplos dessa elaboração em materiais didáticos são: redundância (como uso de repetição, parágrafos, sinônimos, preferência de sintagmas nominais a pronomes), regularidade (ordem canônica, preferência de sintagmas nominais completos a anáforas, coincidir a ordem de enunciação com a ordem de ocorrência dos eventos e o uso de paralelismo - emprego do pronome sujeito nas línguas pro-drop, em que eles não são necessários) e explicitação de relações semânticas e gramaticais (com o uso de conectivos como mas, portanto, contudo, entretanto, por outro lado, apesar de, etc.).

Essa elaboração é condizente e adequada à capacidade de processamento do aprendiz no estágio de desenvolvimento em que ele se encontre. Oferece a oportunidade de contato com itens linguísticos desconhecidos de uma maneira compreensível que lhes possibilita retêlos, favorecendo a aquisição incidental e implícita da língua.

\subsubsection{Prover input rico}

Dado que a aquisição se faz pela exposição ao input (KRASHEN, 1985), materiais com input simplificado cerceiam as oportunidades de desenvolvimento dos aprendizes, na medida em que se restringem ao conteúdo específico de uma aula e àquilo que o aluno já conhece. O mesmo acontece na fala do professor quando ela se limita ao uso dos itens linguísticos apresentados em uma lição (como a prática oral de pattern drills no método Audiolingual ${ }^{53}$ ), expondo os alunos a um input mecânico, repetitivo e artificial.

\footnotetext{
${ }^{53}$ Ver sessões 1.3.1. Abordagens Sintéticas e 1.3.3. Fragilidades nas Abordagens Sintéticas e Analiticas.
} 
Um input rico, não só linguisticamente mais elaborado, mas também mais genuíno, mais variado, configura um ambiente linguístico mais favorável à aquisição, uma vez que oferece mais input e input de melhor qualidade.

Em tarefas pedagógicas, o input oferecido tanto nas amostras elaboradas, quanto na fala do professor, aproxima mais os aprendizes da realidade linguística que encontrarão além da sala de aula, tornando o ensino mais eficiente.

\subsubsection{Encorajar a aprendizagem indutiva de chunks ou parcelas}

Chunks ou parcelas são sequências de palavras que trazem em si um significado ou uso específico na língua. Incluem expressões idiomáticas e combinações sintagmáticas, como locuções prepositivas, locuções substantivas e locuções verbais.

Long (2015) menciona a dificuldade que falantes nativos de inglês encontram para compreender e aprender gênero de palavras e verbos reflexivos em línguas românicas, pois não há equivalentes na língua inglesa. Por outro lado, da experiência em sala de aula, nota-se que que estudantes brasileiros da língua inglesa também encontram dificuldade na aquisição de phrasal verbs - verbos seguidos de preposições que têm como significado uma única palavra em português, como call off, que significa cancelar ou suspender, enquanto call significa chamar. Mas parcelas mais frequentes, como os verbos log in e log out (presentes em contextos de informática como computadores, aplicativos e páginas de internet) são mais facilmente reconhecidos até mesmo por pessoas que não falam ou estudam a língua inglesa. Outro exemplo são parcelas em língua estrangeira que, pelo seu uso frequente, foram incorporadas a língua portuguesa, como hot dog ou top model - termos já registrados em dicionário (HOUAISS, [201-]).

Um exemplo de aprendizagem indutiva de parcelas na língua italiana, com o verbo piacere (gostar): não é necessário entrar nos detalhes de uma explicação gramatical complexa (piacere é um verbo indireto sendo mais frequentes as formas de terceira pessoa do singular e do plural, cuja ordem canônica é: complemento indireto, verbo, sujeito - sendo mais semelhante à estrutura de agradar), o que exigiria dos alunos certo conhecimento metalinguístico - e se caracterizaria como aprendizado explícito da língua, mais dificilmente adquirido pelos aprendizes (N.C. ELLIS, 2008a).

A aquisição desse verbo pode ser facilitada se apresentado aos aprendizes como sequências características da língua, como mi piace, non mi piace e ti piace, que podem ser usadas em uma tarefa pedagógica cujo tema seja lazer, por exemplo, em que os alunos falem 
de suas preferências e possam conhecer as preferências de um colega - aumentando a probabilidade de serem adquiridas incidental e implicitamente (N.C. ELLIS, 2008a).

\subsubsection{Foco na forma}

Foco na forma é o uso reativo de Procedimentos Pedagógicos com o objetivo de trazer, brevemente, a atenção do aluno para determinada forma durante a realização da tarefa pedagógica. Diferentemente do foco nas formas, em que as formas previstas no programa do curso são o eixo central da aula, o foco na forma parte sempre do próprio uso da língua que os aprendizes fazem na aula, ou de uma dificuldade que se apresente durante a realização de tarefas pedagógicas.

A forma em questão é colocada em evidência e tratada brevemente com o objetivo de despertar a percepção do aprendiz para aquela forma verbal, item ou gênero lexical que não tenha sido observada devido à sua baixa relevância (ou por não existir na L1 ou por ocorrer na L2 com uma frequência menor do que a necessária para a aquisição puramente incidental).

O foco na forma pode ser evidenciado pelo próprio aprendiz (quando faz uma pausa para recordá-la ou pede auxílio), por um colega (que aponte a forma adequada), ou pelo professor (quando observa na classe um mesmo ponto de dificuldade ou quando apresenta uma forma semelhante, por ser mais frequente ou para ampliar o vocabulário dos alunos), por exemplo.

Long (2015) afirma que o foco na forma amplia a capacidade de aprendizagem incidental: os aprendizes estão engajados na realização da tarefa e a atenção à forma é breve e secundária. E por ser implícita, significativa e contextualizada, seus efeitos poderão ser mais duradouros. Outros autores consideram que no momento do tratamento da forma o aprendizado está sendo explícito (ELLIS et al, 2020). Mas Long (2015) reforça os benefícios de uma abordagem analítica com foco na forma: ele surge da própria necessidade do aluno, não da delimitação de um currículo e, assim, as questões que surjam durante a realização de tarefas pedagógicas são tratadas em harmonia com a prontidão do desenvolvimento de cada aluno a cada momento.

\subsubsection{Prover feedback negativo}

No processo de aquisição de línguas, o aprendiz pode encontrar exemplos que mostrem que algo é possível na língua-alvo (evidência positiva), exemplos de que algo não é 
possível (evidência negativa direta) ou não encontrar exemplos (evidência negativa indireta).

A evidência negativa direta pode se dar através da correção direta do erro (em que o interlocutor dá a forma correta) ou indireta (quando o professor aponta o problema para que o próprio aprendiz se corrija, por exemplo).

$\mathrm{Na}$ interação, seja com falantes nativos, seja com o professor ou com outros aprendizes, a reação do interlocutor constitui um recurso importante para o aprendiz checar se algo é possível na língua (feedback positivo) ou não (feedback negativo).

Long (2015) considera o feedback negativo um princípio metodológico tanto necessário quanto facilitador da aquisição de línguas. É necessário, por exemplo, nos casos em que certos elementos linguísticos são pouco frequentes nas interações, tornando o input insuficiente para sua aquisição, ou nos casos em que certo uso seja possível na L1, mas agramatical na L2. E facilitador na medida em que contribui para levar a atenção do aprendiz para os elementos que ele tenha usado inadequadamente, como em recasts - um tipo de feedback negativo em que o interlocutor reformula uma sentença incorreta ou incompleta dita por um aprendiz, assim que ela foi feita, alterando algum de seus termos, expandindo-a e mantendo seu significado central (RICHARDS; SCHMIDT 2013).

O feedback negativo, também chamado feedback corretivo, indica algo incompreensível ou inadequado na língua e, além da reformulação (recast), ocorre também na forma de repetição (repetition), verificação de confirmação (confirmation check), pedido de esclarecimento (clarification request), dica metalinguística (metalinguistic clue), correção explícita (explicit correction), indução (elicitation) (LYSTER 1981, LYSTER e RANTA 1997, ELLIS et al. 2020).

A repetição é considerada uma forma de assistência implícita, que pode indicar uma confirmação (feedback positivo) ou um problema de compreensão (feedback negativo), de tal forma que o falante talvez não perceba que houve alguma incompreensão ou o uso inadequado de um termo. A verificação de confirmação também repete a sentença ou parte dela, mas por ter entonação ascendente, é mais explicita que a repetição e pode ser mais facilmente percebida.

O pedido de esclarecimento também ocorre nas interações do dia a dia e por isso é considerado um tipo implícito de feedback, mas é mais claro que a repetição ou a verificação de confirmação.

Uma reformulação também é do tipo implícito: altera um ou mais termos do enunciado mantendo seu significado central, podendo enfatizar os termos alterados através da entonação. 
Formas explicitas de feedback negativo são: dica metalinguística, que aponta uma questão linguística explicitamente através de comentários ou perguntas; correção explícita, que indica claramente que um enunciado é inadequado corrigindo-o; e a indução de formas corretas através de perguntas (e.g. “Como se diz libro em português?”), comentários reticentes a serem completados (e.g. "Eu faço, você....") ou pedindo que o aprendiz reformule enunciado.

\subsubsection{Respeitar os currículos internos e os processos de desenvolvimento do aluno}

Partindo do fundamento de que aquilo que pode ser ensinado depende daquilo que pode ser aprendido em dado momento (PIENNEMANN, 1989), o Ensino Baseado em Tarefas respeita o currículo interno e os processos de desenvolvimento do aluno na medida em que: (1) seu currículo é analítico, determinado pelas necessidades e interesses dos aprendizes, e o foco na forma acontece no momento em que a dificuldade se apresenta, em resposta a erros ou por haver uma forma mais adequada, evitando currículos linguísticos preestabelecidos, pois "[...] professores não podem ensinar o que escolherem quando escolherem" 54 (LONG, 2015, p. 321); (2) reconhece que erros têm papel positivo e são parte natural do processo de aprendizagem, revelando os estágios de desenvolvimento em que os aprendizes se encontram; (3) e trata os erros durante o uso comunicativo da língua através, principalmente, de feedback negativo implícito.

\subsubsection{Promover a aprendizagem cooperativa colaborativa}

O trabalho com tarefas, em pares ou pequenos grupos, promove a interação e a negociação de significados, condições necessárias para a aquisição: "A aprendizagem de línguas se desenvolve a partir do aprender a levar adiante as conversas [...]. Aprende-se a conversar, a interagir verbalmente, e dessa interação se desenvolvem as estruturas sintáticas." ${ }^{55}$ (HATCH, 1978, p. 404)

As tarefas promovem também uma maior participação dos aprendizes e relações mais igualitárias na sala de aula, em que os alunos se sentem mais confiantes para falar e

\footnotetext{
54 " [...] teachers cannot teach whatever they choose, whenever they choose."

55 "Language learning evolves out of learning how to carry on conversations [...]. One learns how to do conversation, one learns how to interact verbally, and out of this interaction syntactic structures are developed."
} 
encorajados a iniciar novos tópicos, num clima de cooperação e auxílio mútuo - "valores humanos básicos, instintivos." ${ }^{56}$ (LONG, 2005, p.78)

Ao trabalharem juntos para a realização de uma tarefa, os aprendizes têm a oportunidade de se auxiliarem e de aprenderem uns com os outros.

Donato (1994, p.51) afirma que "aprendizes são capazes de oferecer suporte guiado a seus pares durante interações colaborativas na L2, de maneiras análogas ao andaime de especialistas documentado em literatura da psicologia do desenvolvimento."57 Andaime ou scaffolding é um mecanismo através do qual um participante cria condições de apoio para que o outro possa se expressar. Pode ser utilizado por pais, professores, ou pelos próprios aprendizes para auxiliar um colega. E, nesse caso, um ouvinte que participe da interação também pode se beneficiar do suporte que o colega recebeu, resultando em desenvolvimento linguístico próprio (DONATO, 1994).

\subsubsection{Individualizar a instrução}

A individualização da instrução propicia condições de atender às necessidades de comunicação de um determinado grupo. Ela é indispensável, pois cada aprendiz tem seus próprios interesses, estilos e estratégias de aprendizagem. Com ela os aprendizes sentem-se mais motivados e confiantes. E através dela pode-se atender a cada aluno na sua necessidade específica, dado que numa mesma turma os alunos encontram-se em diferentes estágios de desenvolvimento.

No Ensino de Línguas Baseado em Tarefas a individualização da instrução se dá através da escolha do conteúdo do curso, que se baseia nas necessidades do aluno; o foco na forma é feito a partir do uso que o aprendiz faz da língua, observando-se seu currículo interno e processos de desenvolvimento; e o trabalho em grupo traz o centro das aulas para o aluno, oferecendo mais oportunidades de interação do que nas abordagens centradas no professor.

Mesmo em turmas com muitos alunos, a individualização da instrução pode ser feita pelo professor nos momentos em que ele provê feedback negativo ao aluno, individualmente, ou para toda a classe, quando percebe e traz à atenção da turma uma questão linguística recorrente, observada ao passar pelos grupos durante a realização das tarefas. Além disso, a análise das necessidades de cada aluno, realizada no início e também reavaliada ao longo do

\footnotetext{
56 "basic, instinctive human values"

57 “....] learners are capable of providing guided support to their peers during collaborative L2 interactions in ways analogous to expert scaffolding documented in the developmental psychological literature."
} 
curso, por meio de conversas com os alunos ou de questionários, pode prover essa individualização, na medida em que as tarefas pedagógicas realizadas pelos alunos em sala de aula são elaboradas a partir de seus interesses e objetivos.

\subsubsection{Procedimentos Pedagógicos}

Os Princípios Metodológicos especificam $o$ que fazer na sala de aula, enquanto os Procedimentos Pedagógicos dizem respeito a como fazer.

Cada aula é única. E boas decisões pedagógicas requerem conhecimento das circunstâncias e características locais, bem como familiaridade com os alunos. Por isso, Long (2015, p.35) ressalta a importância e o valor do professor na escolha dos Procedimentos Pedagógicos que adotará a cada momento na aula, baseando suas decisões em resultados de pesquisas científicas e na sua própria experiência docente: "Professores terão planos de aula, mas precisarão reagir de maneira diferente em tempo real às situações, na medida em que elas se apresentarem." 58

No caso do tratamento de erros, primeiramente, é necessário avaliar se o desvio seria temporário ou um erro propriamente dito (CORDER, 1967). Em se tratando de um erro, cabe ao professor observar: se a correção está condizente com o currículo interno do aluno e seus processos de desenvolvimento ou se ainda não é o momento adequado para o foco na forma em questão; se precisa ser tratado no momento (por se tratar de um traço pouco saliente ou divergente da LM) ou se o próprio uso da língua-alvo oferecerá a frequência necessária para que os alunos observem e percebam o uso adequado por si mesmos; se o tratamento do erro precisa ser feito por escrito ou apenas oralmente; se envolve informação metalinguística e se os alunos poderão se beneficiar dela; se poderá ser dado um feedback negativo implícito ou se será necessário prover feedback corretivo explícito; se o erro que o professor ouve ao se mover pela classe durante o trabalho em grupo pode receber um discreto tratamento individual ou é recorrente e se faz necessária uma breve interrupção do trabalho em grupo para trazê-lo à atenção da classe - são alguns exemplos.

58 “Teachers will have lesson plans, but they will need to react differently in real time to situations as they arise." 


\section{METODOLOGIA}

Neste capítulo apresentam-se a metodologia desta pesquisa etnográfica, seu contexto, os perfis de seus participantes, a definição de tarefa adotada neste trabalho e a estrutura das tarefas elaboradas. Tratam-se, ainda, das dificuldades encontradas na realização da pesquisa, das normas adotadas na transcrição das interações verbais e das categorias de análise da interação verbal

Van Lier (1988) apresenta a etnografia como uma abordagem qualitativa que busca compreender os processos de ensino e de aprendizagem de língua estrangeira, através da análise de dados coletados na sala de aula. Afirma que esse tipo de pesquisa é relevante e valioso para ampliar o conhecimento a respeito do que acontece ali. O autor alerta que os enunciados não devem ser categorizados e comparados isoladamente, mas devem ser estudados no contexto de sua produção, não apenas linguístico ou cognitivo, mas essencialmente social.

A etnografia procura compreender ao invés de provar, a partir de um ponto de vista interpretativo e contextual: a análise é feita a partir das observações pessoais do pesquisador e dos dados coletados em aula. A pesquisa etnográfica é, para Van Lier, uma maneira de diminuir a distância entre a pesquisa e a prática, especialmente se o professor torna-se o pesquisador de sua própria prática docente.

Essa abordagem foi escolhida por possibilitar a integração da autora no papel de professora-pesquisadora no ambiente da coleta de dados de maneira mais natural, participativa e colaborativa, bem como a observação da interação, cujo objetivo é a aquisição da língua: "Por meio da observação, o pesquisador conhece por dentro, sem forçar o contexto, os diferentes pontos de vista da realidade dos participantes e o sentido que eles dão aos acontecimentos, às intenções e às consequências.” (FERRONI, 2012, p.181).

Conforme já ilustrado anteriormente, a pesquisa foi realizada em uma turma de Italiano 2, nível A1-A2 do QECRL (CONSELHO DA EUROPA, 2001) de uma faculdade de letras em uma universidade pública no Estado de São Paulo, em outubro e novembro do ano de 2017, cujos alunos haviam frequentado a disciplina Italiano 1 no semestre anterior. A professora da classe, responsável por ambas as disciplinas, gentilmente cedeu tempo de suas aulas para que esta pesquisa fosse realizada.

Antes de iniciar as gravações, os alunos receberam documento referente à privacidade dos dados fornecidos e, aqueles que quiseram participar da pesquisa, assinaram termo de 
autorização de gravação e uso dos dados (Anexo 1) e responderam a um questionário (Anexo 2). Havia quinze alunos inscritos na disciplina, treze participaram da pesquisa. Entretanto, durante as gravações nem todos estavam presentes e, por isso, a composição dos grupos era diferente a cada aula.

As aulas foram gravadas em vídeo e em áudio. A visão geral da classe, com a participação dos alunos e da professora-pesquisadora, foi registrada em vídeo. E o trabalho em grupo foi registrado em áudio, para que se pudesse ouvir, observar e analisar a interação oral entre os alunos.

Uma dificuldade encontrada foi a incompreensão de algumas gravações ou trechos delas, ou por sobreposição de vozes ou porque os participantes falaram com um tom de voz muito baixo. Algumas gravações em vídeo foram perdidas devido a problemas técnicos no armazenamento dos dados.

As interações verbais entre os alunos foram transcritas, adotando-se as normas de transcrição de Van Lier (1988) com algumas alterações de Ferroni (2012, p.50), descritas a seguir:

\begin{tabular}{|c|c|}
\hline ¿? & estudante não identificado \\
\hline$=$ & dois turnos de palavras em sobreposição \\
\hline$\ldots, \ldots$, etc. & pausa de um segundo \\
\hline (texto) & um só parêntese indica um termo pouco claro \\
\hline$(($ inc $)),(($ risos $))$ & $\begin{array}{l}\text { o parêntese duplo indica uma parte da conversação } \\
\text { incompreensível ou comentários sobre a transcrição, como risos } \\
\text { etc. }\end{array}$ \\
\hline Eh::: & $\begin{array}{l}\text { os dois pontos repetidos por três vezes seguidas indicam um } \\
\text { som prolongado }\end{array}$ \\
\hline$?$ & entoação ascendente \\
\hline$!$ & entoação descendente \\
\hline no- & um hífen indica uma interrupção brusca \\
\hline texto & mudança de código \\
\hline$\underline{\text { texto }}$ & se está lendo \\
\hline (texto) TL & tradução literal \\
\hline (texto) TR & transferência \\
\hline (texto) ES & estrangeirismo \\
\hline (texto) $\mathrm{TF}$ & transfer fonético \\
\hline
\end{tabular}


Nas interações analisadas, observou-se a participação ${ }^{59}$ de seis aprendizes, cujos perfis, traçados por suas respostas ao questionário, podem ser visualizados no anexo 3 , e são apresentados a seguir.

\subsection{Os perfis dos participantes}

Todos os aprendizes são alunos de graduação em Letras. Estão estudando italiano pela primeira vez, tendo iniciado o curso em fevereiro de 2017, mas essa não é a primeira língua estrangeira com que têm contato: todos conhecem também o inglês e alguns, o espanhol. As informações a seguir foram coletadas em outubro de 2017.

F, 28 anos, é graduado em Gestão da Tecnologia da Informação. Conhece um pouco de inglês, sobretudo para ler e escrever, mas não se sente muito confortável para falar. Acredita que o mais importante em um curso de língua estrangeira é estar sempre em contato com a língua, de maneira que se possa aprender o máximo sobre ela em diferentes situações. Para ele, competência comunicativa é a capacidade de se comunicar da melhor maneira possível utilizando os recursos que se tem à disposição. Decidiu fazer o curso porque é descendente de italianos e também porque acha a língua muito bonita. Por ora, seu objetivo é chegar a um nível mais avançado. Considera-se muito motivado a aprender italiano, principalmente para poder ler os clássicos na língua original. Prefere estudar lendo e escrevendo, mas não desconsidera a importância de falar e ouvir. Semanalmente, dedica cerca de cinco horas ao estudo do italiano, mas gostaria de poder estudar mais. Prefere materiais impressos, conhece os vídeos do DFP e já fez parte do curso. Não gosta muito de redes sociais, mas usa. Considera-se mais reservado, contudo, gosta de fazer novos amigos.

G tem 22 anos e quer se graduar em italiano na Faculdade de Letras. Conhece o inglês e se sente razoavelmente confortável para falar. Em um curso de língua estrangeira, considera importante que o aprendizado seja consistente e ao mesmo tempo interessante; que seja atento a questões linguísticas, mas que também contextualize o aluno às questões culturais. Para ele, competência comunicativa são habilidades linguísticas voltadas mais à compreensão e produção oral que interpretativas (leitura de textos, etc.). Decidiu começar o curso porque tem muito interesse pela sociedade, cultura e arte italianas. Sente-se plenamente motivado e pretende estender seus estudos indo à Itália. Gosta de estudar a língua tanto lendo e

${ }^{59}$ As letras G, V, R, F, M, J são usadas para identificar os alunos participantes. PC identifica a participação da professora da classe e PP, da professora-pesquisadora. 
escrevendo quanto ouvindo e falando. Dedica duas a três horas de estudo semanalmente, além das aulas. Prefere materiais impressos e conhece os vídeos de DFP. Gosta de usar redes sociais e se considera uma pessoa extrovertida, porém prefere cultivar as antigas amizades.

J tem 24 anos, conhece o inglês e o espanhol e se sente confortável para falar essas línguas somente em situações informais. Considera importante ter um ambiente confortável e participativo nos cursos de língua estrangeira. Entende que competência comunicativa significa ter input suficiente. Escolheu fazer o curso pela rica cultura literária e audiovisual, com o objetivo de imergir na cultura italiana. Prefere estudar a língua ouvindo e falando e dedica em média duas horas por semana, além das aulas.

M tem 19 anos, pensa que o contato com a língua e a didática são os elementos mais importantes de um curso de língua estrangeira. Para ela, competência comunicativa é a capacidade de transmitir o que queremos. Decidiu começar o curso por causa de seu interesse pela língua e pela cultura italiana. Sente-se motivada, gosta de estudar lendo e dedica-se ao estudo do italiano por alguns minutos nos finais de semana. Prefere materiais de estudo impressos, conhece os vídeos de DFP e os considera úteis. Ela se vê como uma pessoa reservada e gosta acessar redes sociais.

R, 39 anos, é graduado em Sistemas de Informação, graduado e pós-graduado em Administração. Conhece as línguas espanhola e inglesa. Embora não as utilize sempre e tenha uma fluência menor do que gostaria, sente-se confortável falando essas línguas. E considera que o mais importante em um curso de língua estrangeira é falar, comunicar-se da maneira mais clara possível. Entende que competência comunicativa significa comunicar-se sem "ruídos", sendo clara a interpretação. Seu maior interesse é nas outras áreas da Letras. O italiano é apenas uma língua que gostaria de saber por questões familiares. Sente que talvez lhe falte a motivação, mas que o interesse por uma nova língua já é suficiente. Além das aulas, estuda italiano por duas horas, semanalmente. Prefere estudar lendo e escrevendo do que ouvindo e falando. Gosta mais de materiais on-line, conhece os vídeos de DFP, mas ainda não os assistiu. Gosta de redes sociais e se considera uma pessoa reservada, que prefere cultivar as antigas amizades.

V, 21 anos, sente-se confortável para falar o inglês e ainda está adquirindo confiança para estabelecer conversas em italiano. Pensa que o mais importante em curso de língua estrangeira é entrar em contato com a língua de forma mais natural e intuitiva, principalmente com o auxílio da conversação. Para ela, competência comunicativa é a capacidade de entender e se fazer entender. Decidiu começar o curso porque gosta muito da arte italiana e isso despertou sua curiosidade pela língua: pretende compreendê-la bem e conhecer melhor a 
cultura. Sente-se muito motivada, principalmente por poder conhecer melhor a cultura italiana. Gosta de estudar a língua ouvindo e falando, mas acredita que ler e escrever também sejam fundamentais e ajudem na fixação. Além da sala de aula, tenta se dedicar ao estudo da língua cerca de três vezes por semana, e também assistir a séries de TV dubladas em italiano. Prefere materiais impressos e conhece os vídeos de DFP. Gosta de redes sociais. Considera-se um pouco reservada, mas gosta muito de fazer novos amigos.

A professora da classe (PC) é italiana, também fala português e espanhol e lê bem em francês. Vive no Brasil desde 2004. Quando chegou no país, adquiriu a língua falando com os brasileiros e, no início, teve aulas individualmente, com uma professora particular. Graduouse em Letras na Itália, onde também fez uma especialização para ensinar italiano a estrangeiros. Fez mestrado e doutorado no Brasil, onde leciona cursos de graduação e pósgraduação, orienta alunos e desenvolve pesquisas na área de ensino e aprendizagem de italiano como LE. Realizou seu pós-doutorado em Portugal. Nas aulas de língua e cultura italiana, privilegia o trabalho em grupo e as oportunidades de interação oral.

A professora pesquisadora (PP) tem 37 anos, é brasileira, graduada em Letras (Latim). Estudou inglês em escolas de língua dos 13 aos 19 anos. Aprendeu a língua italiana na infância e adolescência, com a sua família no Brasil e visitando os parentes na Itália durante as férias escolares. Começou a estudar italiano formalmente aos 17 anos, com aulas particulares, e dos 19 aos 23 anos, estudou língua e literatura italiana na faculdade de Letras. Leciona italiano, inglês e português para estrangeiros há 18 anos.

\subsection{As tarefas}

Dentre as várias definições de tarefa descritas na literatura especializada (Anexo 1), nesta pesquisa destacam-se os conceitos de tarefa e de tarefa pedagógica definidos por Long:

Tarefas são as atividades do mundo real em que as pessoas pensam quando planejam, conduzem ou relembram o seu dia. [...] Depois de passarem por algumas modificações, as tarefas são usadas como o conteúdo de um currículo de tarefas, que consiste em uma série de tarefas pedagógicas cada vez mais complexas. Tarefas pedagógicas são as atividades e os materiais com que professores e/ou alunos trabalham na sala de aula ou em outro ambiente instrucional. ${ }^{60}(2015$, p. 3$)$

\footnotetext{
60 "Tasks are the real-world activities people think of when planning, conducting, or recalling their day. [...] After undergoing some modifications, the tasks are used as the content of a task syllabus, which consists of a series of progressively more complex pedagogic tasks. Pedagogic tasks are the activities and the materials that teachers and/or students work on in the classroom or other instructional environment."
} 
Nesta pesquisa, o termo tarefa pedagógica ou simplesmente tarefa, se refere àquela realizada em sala de aula, com o objetivo de aprender uma língua estrangeira e o termo tarefa-alvo (LONG, 2015) se refere a uma tarefa real de interesse dos aprendizes.

Willis (1996) propõe seis tipos de tarefa: listar, ordenar e classificar, comparar, resolver um problema, compartilhar experiências pessoais e tarefas criativas, que combinam mais de um tipo. Tarefas compõem-se de três fases: pre-task (pre-tarefa), during task (durante a tarefa) e post-task (pós-tarefa).

Pre-task, é fase inicial que prepara os aprendizes para a realização da tarefa: mostrando-se um modelo, realizando-se uma similar, fazendo atividades ${ }^{61}$ que lhes forneçam as informações necessárias para a realização da tarefa central, ou através do planejamento estratégico. Os alunos se organizam e definem como irão realizá-la.

During-task é o momento em que os alunos realizam, em grupos, a tarefa propriamente dita e o professor está disponível para auxiliá-los caso necessitem.

Post-task é a fase de revisão, reflexão e conclusão. É o momento em que se tem oportunidade de repetir a tarefa para que os aprendizes possam se expressar com maior clareza e precisão; de refletir sobre como ela foi realizada, para a avaliação tanto da tarefa quanto do desempenho dos alunos; e de trazer a atenção dos aprendizes para aspectos linguísticos relevantes que tenham surgido ao longo do trabalho (ELLIS, 2003).

Para a coleta de dados desta pesquisa, foram elaboradas tarefas pedagógicas baseadas em tarefas reais do interesse dos aprendizes, "[...] o que eles precisam ser capazes de fazer na nova língua." ${ }^{62}$ (LONG, 2015, p.3). Essas tarefas-alvo foram identificadas pelo seu perfil, traçado a partir de um questionário (Anexo 2) e de conversas em sala de aula. Trata-se de um grupo de alunos brasileiros que cursam a faculdade de Letras e que se interessam pela língua e cultura italianas. Têm o objetivo comum de desenvolver a habilidade de se comunicar com clareza em italiano e gostariam de ir à Itália, para turismo, para estudar ou para viver por algum período. Reconhecem o lugar da dimensão linguística na aprendizagem da língua, mas consideram fundamental a importância da dimensão sociolinguística e das oportunidades de interação oral para o desenvolvimento da competência comunicativa.

\footnotetext{
61 "no ensino de línguas, um termo geral para qualquer procedimento em sala de aula que requer dos alunos o uso e a prática de seus recursos linguísticos disponíveis." (RICHARDS; SCHMIDT, 2010, p.9)

"in language teaching, a general term for any classroom procedure that requires students to use and practise their available language resources."

62 "[...] what they need to be able to do in the new language."
} 
Na elaboração das tarefas pedagógicas, foram utilizados vídeos da série ficcional de Dire, Fare, Partire! ${ }^{63}$ (UNIVERSIDADE DE SÃO PAULO, [201-]), cujo protagonista é Tarcísio, um brasileiro de origem italiana que está se organizando para viver na Itália. Ele conta com o apoio de Marcelo, um primo que adquiriu a língua quando morou no país, aprendendo de maneira autodidata. Tarcísio pratica italiano com seu primo e também com uma amiga virtual, Elisa, uma italiana que ele conheceu on-line por intermédio de Marcelo.

Tarcísio estuda italiano formalmente e se preocupa com a pronúncia, o vocabulário e as estruturas da língua. Dedica-se ao estudo e desenvolvimento da competência linguística, mas revela pouca competência intercultural. Marcelo, por outro lado, não demonstra uma competência linguística tão elevada quanto sua competência intercultural: "[...] conhece a proxêmica (estudo relativo às distâncias entre as pessoas e seu uso comunicativo), a vestêmica (o uso comunicativo da indumentária), a cinésica (o uso comunicativo do corpo, dos gestos, dos movimentos, do uso das expressões do rosto em busca do contato corporal e visual) e a objetêmica (o uso comunicativo dos objetos).” (BACCIN; MAGGIO; ORTALE, 2017, p.107). Já Elisa oferece um modelo de língua de um falante nativo do italiano. Ela não conhece a cultura brasileira ou mesmo a língua portuguesa.

DFP é um conjunto de materiais elaborado para o estudo e o ensino de língua italiana para brasileiros, com foco no público universitário discente e docente das faculdades de Letras. Trata de elementos linguísticos e culturais em vídeo-aulas, atividades on-line e apostilas disponíveis para download e impressão.

Nesta pesquisa, a partir dos episódios 5, 7 e 9 da série ficcional de DFP, foram elaboradas tarefas pedagógicas com os temas: Cercando lavoro (Procurando trabalho), L'abito non fa il monaco (O hábito não faz o monge), Ospitalità (Hospitalidade), Mangia che ti fa bene! (Come que é bom pra você!), Chi ha lingua va a Roma (Quem tem boca vai a Roma). Elas refletem as seguintes tarefas reais, respectivamente: procurar uma oferta de trabalho; vestir-se adequadamente para uma entrevista de trabalho; hospedar; criar uma receita; dirigir-se a um local desconhecido. Em todas elas realiza-se a tarefa-alvo "conversar em italiano", buscando prover oportunidades para os alunos expressarem as próprias opiniões.

Durante as aulas, professora-pesquisadora se comunica com os alunos em língua italiana; os alunos são incentivados a se comunicar em italiano, mas têm liberdade para usar a língua materna ou também outras línguas estrangeiras que conheçam.

${ }^{63}$ Disponível em: $<$ https://cursosextensao.usp.br/course/view.php?id=131>. Acesso em 5 jul. 2017. 
O tempo indicado para a realização de cada etapa da tarefa é apenas uma referência em termos de planejamento da aula; na prática, priorizou-se a necessidade dos alunos.

\subsection{Categorias de Análise}

Van Lier (1988) considera a língua em comunicação como um sistema autorregulatório, em que "a regulação é feita através de feedback e monitoramento constantes por todos os participantes" ${ }^{64}$. O monitoramento pode ser feito de duas maneiras, ambas consideradas pelo autor "ingredientes essenciais na aprendizagem" ${ }^{65}$ : através da interação, em um "esforço cooperativo" 66 entre os participantes, ou internamente ${ }^{67}$. Hesitação e substituição de palavras são indícios desse monitoramento interno, em que cada participante, através de recursos internos, armazenados, e externos, contextuais, monitora e regula a própria fala.

$\mathrm{Na}$ análise da interação verbal entre os aprendizes durante a realização das tarefas propostas nesta pesquisa, observou-se que o monitoramento cooperativo, que emerge da aprendizagem colaborativa e cooperativa (LONG 2015), realizou-se através do emprego de estruturas andaime (scaffolding) em que um aprendiz dá suporte ao outro complementando suas falas, auxiliando o colega a se expressar com maior clareza e precisão.

O monitoramento pessoal, descrito por Van Lier (1988) como aquele que acontece internamente, pode ser visto como a ação do Monitor, proposto por Krashen (1981), através do qual os aprendizes, mostrando sua consideração por um uso adequado da língua, editam a própria produção, aperfeiçoando seus níveis de precisão (accuracy) e favorecendo a aquisição da LA. Na presente análise, verificou-se que, em níveis iniciantes, os aprendizes por vezes recorrem a regras e termos na LM para fazer esse monitoramento interno.

No tocante ao uso da LM (ou de outras LE diferentes da LA) como estratégia de comunicação e aprendizagem, nesta análise valeu-se da taxonomia proposta por Ferroni (2012), que identifica os seguintes tipos de transferência consciente (conscious transfer): troca de código (codeswitching), estrangeirismo, transferência (transfer), transferência fonética e tradução literal - os quais foram categorizados por ela nos seguintes subtipos:

a) troca de código negociada com o colega - emprego de um termo ou expressão na LM ou em LE, geralmente precedida de sinais de hesitação (pausa, som

\footnotetext{
64 "the regulating is done by constant feedback and monitoring by all participants" (p.182)

65 "essential ingredients in learning" (p.182)

66 "cooperative effort" (p.182)

${ }^{67}$ Neste trabalho, o monitoramento através da interação, é denominado monitoramento cooperativo e o monitoramento que acontece internamente, é denominado monitoramento pessoal.
} 
prolongado, repetição, pedidos diretos de auxílio), marcada pela interação e negociação de significado em busca do termo ou expressão adequada na LA;

b) troca de código negociada pelo falante - emprego de um termo ou expressão na LM ou em LE em que o falante expressa verbalmente suas tentativas até realizar o termo ou expressão adequada na LA;

c) troca de código não negociada - é precedida de sinais de hesitação que indicam um empenho do falante, mas a troca não é resolvida, por desconhecimento de correspondente na LA;

d) troca de tradução - estratégia empregada para fins cooperativos em que o falante, recorre à LM ou a outra LE como recurso de facilitação da compreensão, de agilidade e de fluidez;

e) troca de código lapsus - produzida incidentalmente, é interrompida e autorreparada na sequência da fala;

f) troca de código para refletir sobre a atividade - comentários que auxiliam na realização da atividade;

g) troca de código para fazer reflexões metalinguísticas - comentários que tratam de aspectos gramaticais;

h) troca de código para falar de aprendizagem - reflexões metacognitivas para si mesmo, em tom de voz baixo ou sussurrado;

i) troca de código para gerenciar a conversação - uso de marcadores discursivos (como “eh”, “oh”, “ô”, “né”, “nossa!”) ou outros termos na LM com o objetivo de "iniciar e finalizar uma conversa, fazer comentários e exclamações, tomar e passar a palavra, pedir e dar consentimento, chamar a atenção e checar a compreensão do interlocutor, sinalizar a recepção" (p.95);

j) troca de código usada para fazer comentários que não pertencem ao contexto escolar;

k) estrangeirismos - criação de palavras para suprir faltas linguísticas no repertório do aprendiz, que podem ser reparados ou não serem percebidos pelos interlocutores;

1) transferência (transfer) - emprego de estrutura da LM usando léxico da LA, sendo que essa transferência pode ser reparada ou não ser percebida;

m) transferência fonética - termo na LA pronunciado com sons da LM ou uso de um termo na LM, com pronúncia da LM, para expressar efeitos e funções próprios que não existem na LA; 
n) tradução literal não negociada - termo traduzido literalmente para a LA que não é reparado;

o) tradução literal negociada pelo falante - termo traduzido literalmente para a LA que é autorreparado;

p) tradução literal negociada com o colega - termo traduzido literalmente para a LA que é heterorreparado.

No que diz respeito ao fornecimento de feedbacks negativos ou corretivos pelos próprios colegas, pela professora da classe ou pela professora pesquisadora, adotou-se a tipologia descrita por Ellis et al. (2020): repetição, confirmação, pedido de esclarecimento, dica metalinguística, correção explícita, indução e reformulação (para a descrição de cada tipo, ver sessão 1.5.1.7 Prover feedback negativo). 


\section{INTERAÇÃO VERBAL ENTRE APRENDIZES DURANTE A REALIZAÇÃO DE TAREFAS}

Este capítulo trata da coleta de dados, apresentação e análise das tarefas pedagógicas elaboradas para esta pesquisa. Trata também da análise da interação verbal durante a realização das tarefas. As análises têm como objetivos identificar e descrever elementos que possam contribuir para o desenvolvimento da expressão oral dos alunos, assim como verificar os efeitos do Ensino de Línguas Baseado em Tarefas e de seus Princípios Metodológicos (LONG, 2015) na aprendizagem de italiano como LE em níveis iniciantes, A1-A2 do QECRL (CONSELHO DA EUROPA, 2001).

\subsection{Coleta de Dados}

Foram realizados doze encontros, com a participação de treze alunos. Ao examinar as gravações, observou-se que as aulas cujo eixo central eram produções orais individuais e discussões guiadas pela professora-pesquisadora com a participação de toda a classe, por não contemplarem a aprendizagem cooperativa e colaborativa, Princípio Metodológico do Ensino de Línguas Baseado em Tarefas (LONG, 2015), não favoreceram a interação entre os aprendizes, diminuindo as oportunidades de negociação de significado e de elaboração do output, facilitadores da aquisição.

Nessas aulas observaram-se poucas oportunidades para os alunos falarem, no sentido que alguns participam mais e outros ficam em silêncio. Verificou-se, assim, que o trabalho e as discussões em dupla puderam oferecer a possibilidade de ambos interagirem mais, principalmente quando se trabalha com um colega com quem se tem mais afinidade, pois alguns alunos se sentem expostos ao falar para toda a turma. As conversas em duplas ou pequenos grupos, portanto, tiveram dois objetivos: aumentar a produção oral, output (SWAIN, 1985), ampliar as oportunidades de interação a todos os aprendizes (LONG, 2015) e auxiliar a baixar o filtro afetivo dos alunos (KRASHEN, 1981), favorecendo a aprendizagem.

O corpus desta pesquisa se compõe, assim, de 5 tarefas pedagógicas (LONG, 2015) que foram gravadas em seis encontros, com duração de cerca de 45 minutos cada. Nos termos de Willis (1996), são tarefas criativas, que incluem mais de um tipo (ouvir, organizar e classificar, comparar, resolver um problema ou compartilhar experiências pessoais) e podem se desdobrar em outras, compondo-se de várias etapas. 


\subsection{Tarefas Pedagógicas elaboradas a partir dos vídeos de Dire Fare Partire!}

Com as tarefas a seguir, que têm como ponto de partida os vídeos dos episódios 5,7 e 9 da série ficcional de DFP, procurou-se contemplar os seguintes interesses e objetivos dos aprendizes: "entrar em contato com a língua através da conversação", "estando atentos a questões linguísticas e culturais", "em um ambiente confortável e participativo", "para desenvolver a capacidade de transmitir o que queremos."

\subsubsection{Cercando Lavoro}

No episódio da vídeo-aula 5, Tarcísio, que está se organizando para passar uma temporada com seus familiares italianos, faz uma lista de possibilidades de trabalho para si na Itália. Conversa com Elisa a respeito de sua viagem, vida pessoal e interesses profissionais. $\mathrm{Na}$ sequência, conversa com seu primo Marcelo a respeito do que levar consigo na viagem. Marcelo, com quem conversa em italiano a respeito de hábitos e características da cultura italiana, aconselha que o primo não leve muitas roupas e que procure se vestir como os italianos, pois, segundo afirma, vestir-se bem, e adequadamente, em cada ocasião é uma questão importantíssima para eles.

Pre-task - Primeiramente, a professora pergunta para a classe se alguém já usou a internet para buscar vagas de trabalho. Há uma conversa sobre as experiências dos alunos na procura de vagas. O objetivo aqui é introduzir o tema, identificar e oferecer os itens linguísticos que os alunos necessitem para a realização da tarefa, bem como apresentar vocabulário chave para a compreensão do vídeo. Em seguida, os alunos são convidados a assistir ao episódio e a escrever duas listas: uma com os interesses de Tarcísio e outra com os conselhos de Marcelo. O objetivo desta atividade de compreensão é coletar informações que serão compartilhadas e usadas na realização da tarefa em grupos.

During-task - Tarefa: Cercando un lavoro per Tarciso ${ }^{69}$. O objetivo geral dessa tarefa é promover a produção oral na língua-alvo através da troca entre os alunos. Primeiramente, eles são estimulados a conversar, com a proposta de três perguntas a serem discutidas nos grupos: (1) quais são os interesses e as habilidades de Tarcísio; (2) se a língua seria um fator decisivo para que ele encontrasse trabalho; (3) que tipo de trabalho seria adequado a ele nesse

\footnotetext{
${ }^{68}$ Interesses e objetivos dos aprendizes identificados no Perfil dos Participantes (Capítulo 2.2.) através de questionário (Apêndice 2).

${ }^{69}$ Procurando um trabalho para Tarcísio.
} 
momento. A pergunta (1) tem o objetivo de compartilhar as informações que os alunos identificaram na pre-task e checar sua compreensão do vídeo assistido. As perguntas (2) e (3) têm o objetivo de oferecer aos alunos a oportunidade de expressar suas próprias opiniões a respeito dos temas propostos. Em seguida, com base nessa discussão, os alunos devem procurar ofertas de trabalho para Tarcísio em sites italianos de vagas.

Post-task - A professora pesquisadora retoma a discussão realizada em grupos na fase anterior, desta vez com a participação de toda a classe, com os objetivos de: verificar a compreensão do vídeo, compartilhar as opiniões de cada grupo expandindo a discussão, conhecer os resultados finais da realização da tarefa (quais ofertas de trabalho foram encontradas on-line). O objetivo secundário, não menos importante, é prover feedback negativo e trazer a atenção dos alunos para o foco na forma, ou seja, esclarecendo questões linguísticas que emerjam do uso que os aprendizes fazem da língua durante a realização da tarefa.

O objetivo geral dessa tarefa pedagógica é desenvolver a expressão oral dos aprendizes por meio da construção conjunta de instrumentos úteis para se buscar uma vaga de trabalho. 


\section{Cercando lavoro}

Dire, Fare, Partire! - Video Lezione 5 parte A -

http://eaulas.usp.br/portal/video.action?idltem $=5761$

In plenum:

Avete mai cercato lavoro su internet? Com'è stata la vostra esperienza?

\section{Compreensione (5 minuti)}

Guardare le scene e completare la griglia

2:26-4:40 (Tarcisio faz uma lista de possibilidades de trabalho)

4:40-7:39 (Tarcisio conversa com o primo que dá dicas de hábitos dos italianos - vestuário e comida)

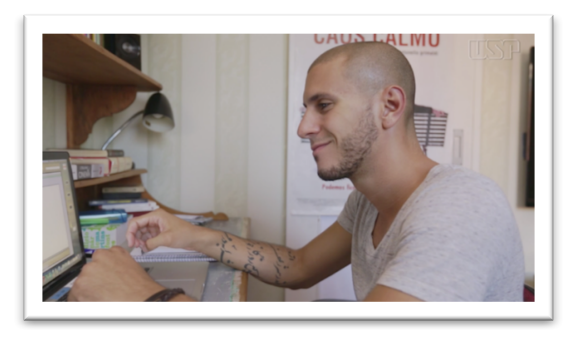

Interessi di Tarcisio

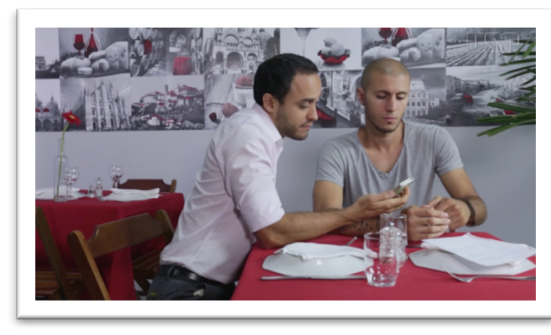

Consigli di Marcelo

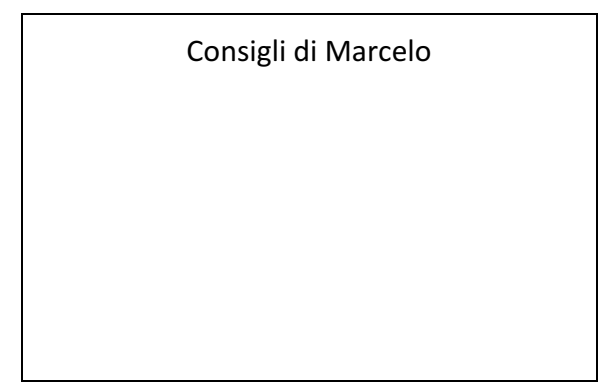

\section{ATTIVITÀ 1 (11/10/17) - Cercando un lavoro per Tarcisio (15 minuti)}

In gruppi di 3 o 4 persone, discutete:

- Quali sono gli interessi e le abilità di Tarcisio?

- La lingua sarebbe un fattore decisivo per trovare lavoro?

- Che tipo di lavoro pensate sarebbe adatto a lui in questo momento?

Accedere il sito infojobs.it (o un altro scelto da voi) e cercare corsi e opportunità di lavoro adatte a Tarcisio. Presentare alla classe le vostre proposte.

Figura 1 - Folha de atividades da tarefa pedagógica Cercando Lavoro 


\subsubsection{Cercando Lavoro: L'abito non fa il monaco}

O tema desta aula é "Procurando trabalho: O hábito não faz o monge", uma continuação e extensão do tema da tarefa anterior. $O$ objetivo pedagógico é o desenvolvimento da produção oral, com foco na competência intercultural. A tarefa real experienciada nesta aula é conversar expressando as próprias opiniões.

$\mathrm{Na}$ terceira cena ${ }^{70}$ do episódio da vídeo-aula 5 (UNIVERSIDADE DE SÃO PAULO [201-]), Marcelo e Tarcísio conversam a respeito da vestêmica (uso comunicativo da indumentária). Os brasileiros se vestem mais informalmente e Marcelo aconselha o primo a deixar para trás suas roupas, de estilo principalmente esportivo, para evitar excesso de bagagem e se adequar ao modo dos italianos: sempre muito elegantes, têm uma maneira especifica de se vestir em cada ocasião - entrevista de trabalho, jantar com os amigos, dar uma volta na praça, etc.

Para o desenvolvimento deste tema, a aula foi organizada em duas tarefas e se subdivide em cinco fases: Pre-task 1, During-task 1, Pre-task 2, During-task 2, Post-task.

Pre-task 1 - Inicialmente a professora pergunta para a classe o quanto as roupas são importantes para uma entrevista de trabalho. Há uma conversa sobre as opiniões dos alunos a esse respeito, cujo objetivo é identificar e apresentar os itens linguísticos e lexicais necessários para a compreensão do vídeo. Em seguida, os alunos assistem à cena em busca de informações de como se vestem os italianos, segundo Marcelo. O objetivo dessa atividade de compreensão é coletar informações para realizar em grupo a tarefa 1.

During-task 1 - Tarefa 1: Come si vestono gli italiani. ${ }^{71}$ Os alunos conversam em grupos, compartilhando as informações coletadas do vídeo assistido na fase anterior e verificam sua compreensão. O objetivo desta tarefa é a produção oral.

Pre-task 2 - Os alunos leem pequenos textos com sugestões de como se vestir de modo apropriado à cultura de trabalho italiana e causar uma boa impressão em uma entrevista (WIKIHOW, [20--]). Nesta atividade, os alunos têm a oportunidade de construírem juntos a compreensão do texto, auxiliando uns aos outros a expandir seu vocabulário. O estudo da pronúncia e de itens linguísticos também pode emergir da leitura em grupo.

During-task 2 - Tarefa 2: Come vestirsi per fare buona impressione ad un colloquio di lavoro. ${ }^{72}$ Após a leitura dos textos, é feita uma discussão em grupo a respeito das sugestões do

\footnotetext{
${ }^{70}$ Vídeo-aula 5, primeira parte. Disponível em: $<$ https://cursosextensao.usp.br/course/view.php?id=131\&section=5 $>$ Acesso em 20 jan. 20.

${ }^{71}$ Como se vestem os italianos.
} 
texto e de que conselhos os aprendizes dariam a Tarcísio sobre o que vestir em uma entrevista de trabalho na Itália. O objetivo é expressar as próprias opiniões em uma conversa com os colegas.

Post-task - A professora-pesquisadora convida a classe a conversar sobre o tema, com os objetivos de expandir a discussão realizada na fase anterior, verificar a compreensão e analisar elementos linguísticos de interesse dos alunos.

As figuras 2 e 3 a seguir mostram as folhas de atividades desta tarefa pedagógica.

\footnotetext{
${ }^{72}$ Como se vestir para dar uma boa impressão em uma entrevista de trabalho.
} 


\section{Cercando Lavoro \\ L'abito non fa il monaco}

\section{ATTIVITÀ 2 (16/10/17) - Abbigliamento adatto ad un colloquio di lavoro (5 minuti)}

Per voi, quanto è importante l'abbigliamento per un colloquio di lavoro?

Guardate nuovamente la scena e rispondete: secondo Marcelo, come si vestono gli italiani? (4:405:55)

\section{In gruppi di 3 o 4 persone, leggere i testi e discutere (10 minuti)}

https://www.wikihow.it/Vestirsi-per-Fare-Buona-Impressione-a-un-Colloquio-di-Lavoro

- Scambiatevi idea sulle vostre opinioni sui consigli sottoelencati.

- Che consigli dareste a Tarcisio su cosa vestire per il colloquio di lavoro?

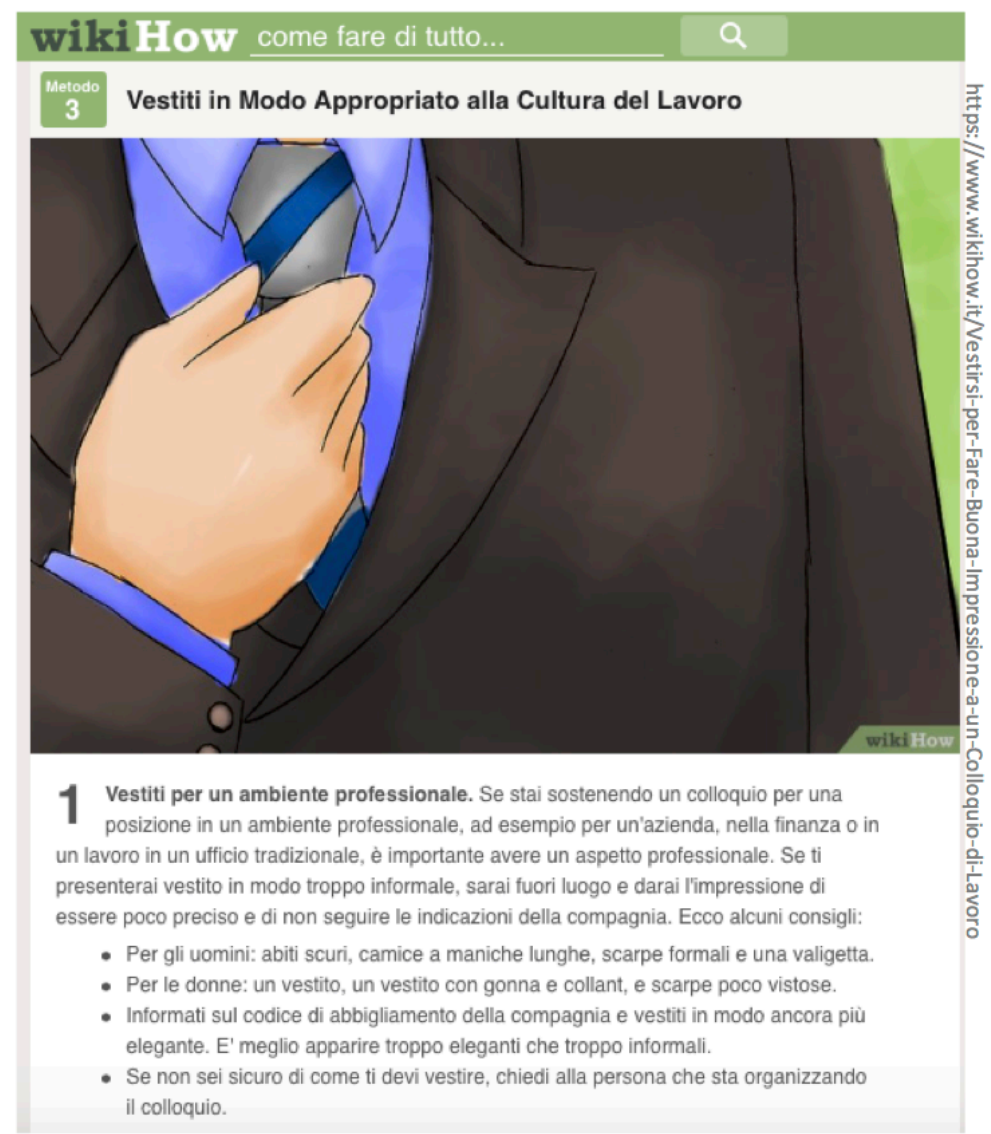

Figura 2 - Folha de atividades da tarefa pedagógica Cercando Lavoro: L'abito non fa il monaco (página 1) 


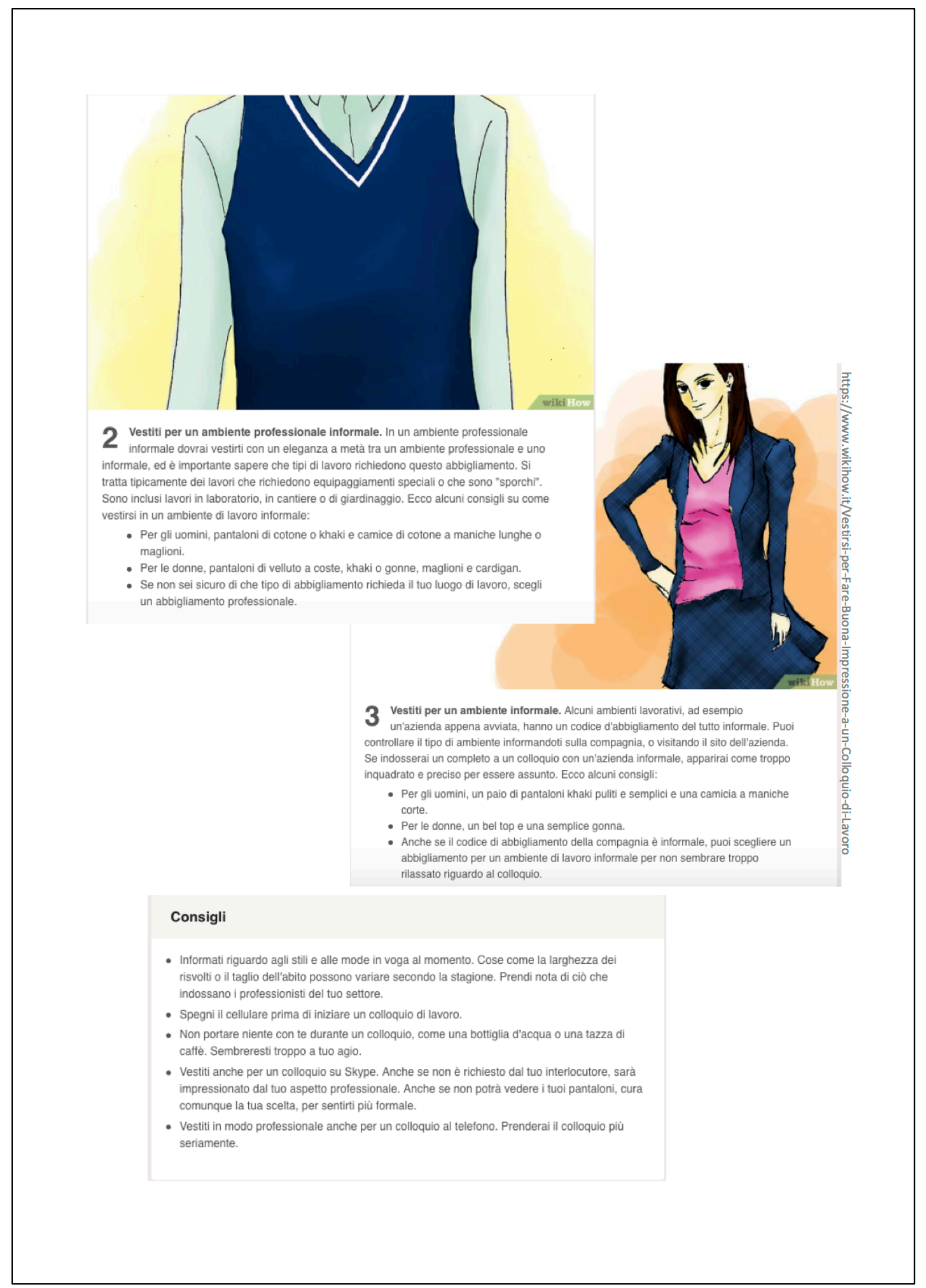

Figura 3 - Folha de atividades da tarefa pedagógica Cercando Lavoro: L'abito non fa il monaco (página 2) 


\subsubsection{Ospitalità}

O tema desta aula é Hospitalidade. No episódio ficcional da vídeo-aula 7, Tarcísio fala ao telefone com um tio italiano, Angelo, e procura um lugar para se hospedar. O tio explica que não pode hospedá-lo porque há uma lei que determina o número máximo de habitantes por moradia, mas o convida a visitá-los e comer um prato típico, Pearà. Na cena seguinte, Tarcísio conversa com Marcelo sobre essa lei, como são feitas as fiscalizações, e sobre a famosa Pearà do Zio Angelo.

Pre-task - O objetivo dessa atividade é introduzir o tema e o vocabulário útil para a compreensão do vídeo e, através dos costumes dos alunos, trazer à tona elementos da cultura brasileira. A professora conversa com a turma a respeito de hospitalidade: se viajam com frequência, onde se hospedam quando fazem viagens, se recebem hospedes em casa e o que significa para eles receber bem um hóspede. Em seguida os alunos assistem às duas cenas e buscam respostas para perguntas de compreensão, com o objetivo de coletar informações para a realização da tarefa a seguir.

During task - Nesta tarefa em grupos, os alunos compartilham as informações que compreenderam do vídeo e suas opiniões a respeito da lei italiana que define o número de habitantes por moradia, da hospitalidade de Zio Angelo, do costume de se cozinhar para receber alguém. O objetivo desta tarefa é desenvolver a expressão oral e a competência intercultural.

Post-task - A professora verifica com a turma as atividades realizadas, auxilia com itens linguísticos que se apresentam, e retoma a discussão com os alunos a respeito das diferenças culturais relacionadas à hospitalidade.

Esta tarefa se desdobra na seguinte, Mangia che ti fa bene ${ }^{73}$, que trata de culinária típica e criativa.

\subsubsection{Mangia che ti fa bene!}

O objetivo desta aula é conversar sobre pratos típicos e criar uma receita. Para o desenvolvimento deste tema, a aula foi organizada em duas tarefas e se subdivide em seis fases: Pre-task 1, During-task 1, Post-task 1, Pre-task 2, During-task 2, Post-task 2.

${ }^{73}$ Coma que te faz bem! 
Pre-task 1 - Atividade de compreensão: assistir ao vídeo de um cozinheiro do restaurante italiano Osteria Verona Antica preparando Pearà e indicar na folha de atividades quais das informações estão presentes no vídeo; assistir novamente buscando mais informações sobre os ingredientes e o modo de preparo desse prato típico veronês.

During task 1 - Compartilhar as informações com o colega e escrever juntos a receita do cozinheiro italiano.

Post-task 1 - A professora verifica com os alunos as atividades realizadas e auxilia com os itens linguísticos que se surgem.

Pre-task 2 - Em grupos, fazer uma tempestade de ideias (brainstorming) para criar uma adaptação da Pearà ao paladar e ingredientes e brasileiros.

During task 2 - Escrever juntos a receita. A professora circula pelos grupos auxiliando a esclarecer dificuldades linguísticas que vão surgindo durante a realização da tarefa.

Post-task 2 - Cada grupo apresenta a sua receita com o objetivo de retomar o que foi discutido, para que os aprendizes possam se expressar com mais clareza e precisão. 


\section{Ospitalità}

Dire, Fare, Partirel - Video Lezione 7 - parte 1

http://eaulas.usp.br/portal/video.action?idltem $=5774$

In plenum: Parliamo di ospitalità.

Come si può definirla?

Attività 1: In coppia, guardate le scene e rispondete alle

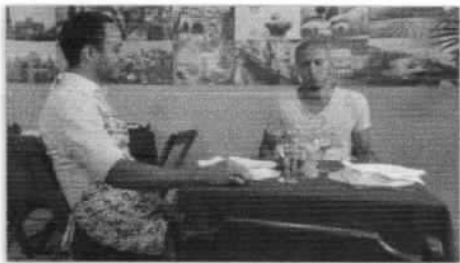
domande. (6:58-9:06-11:55)

1) A chi telefona Tarcisio?

2) Chi è Fabio?

3) Per quale squadra fa il tifo Tarcisio?

4) Quando comprerà i biglietti Tarcisio?

5) La famiglia di Tarcisio lo potrà ospitare?

6) Cos'è la "Pearà"?

7) Quali sono gli ingredienti della "Pearà", secondo Marcelo?

\section{Attività 2}

\section{Mangia che ti fa bene!}

https://www.youtube.com/watch?v=dLNImliACIY\&t=64s

Vedremo il video di un chef italiano preparando la "Pearà". Indicate se le seguenti frasi sono veramente presenti:

1) il midollo si brucia

2) non deve essere tostato

3) ci vogliono circa 45 minuti

4) non si attacchi

5) il colore non cambierà

6) con l'aiuto della frusta, iniziamo a grattugiare

7) il latte inizierà ad addensarsi

8) fino a diventare un composto liquido

9) cuocere per due ore

10) aggiungere sale per dare più gusto

11) la salsa diventi poco liquida

12) impasto di maiale con l'aggiunto delle cottene

13) leviamo gli spaghi da un lato

14) l'acqua con cui cuocere i cotechini deve essere fredda

Attività 3: In coppia, scrivete la ricetta del cuoco dell'Osteria Verona Antica.

Ingredienti

Modo di fare

Attività 4

Rivisitate la ricetta sostituendo gli ingredienti che non vi piacciono o che non si trovano in Brasile per altri facilmente reperibili.

Figura 4 - Folha de atividades das tarefas pedagógicas Ospitalità e Mangia che ti fa bene! 


\subsubsection{Chi ha lingua va a Roma}

O tema desta aula é Quem tem boca vai a Roma. Foi organizada em duas tarefas e se subdividem em seis fases: Pre-task 1, During-task 1, Post-task 1, Pre-task 2, During-task 2, Post-task 2. O objetivo desta aula é desenvolver a compreensão e a expressão orais, realizando a tarefa-alvo de dirigir-se a um local desconhecido.

No episódio ficcional da vídeo-aula 9, Tarcísio conversa com sua amiga Elisa por vídeo-chamada sobre o contato que recebeu de uma produtora italiana interessada em seu currículo e sobre o material audiovisual que ele criou e enviou, para que a equipe pudesse conhecer o estilo de seu trabalho. Conversam também sobre as correspondências e fotografias antigas de sua avó italiana. Na cena seguinte, Tarcísio vai ao consulado buscar seu passaporte italiano e ali recebe informação de como se dirigir ao setor.

Pre-task 1 - Atividades de compreensão: assistir ao vídeo e indicar na folha de atividades quais falas são de Tarcísio e quais são de Elisa; conferir as respostas com um colega.

During task 1 - Assistir novamente, fazer uma lista dos assuntos sobre os quais eles conversam e compartilhar as informações coletadas com o grupo.

Post-task 1 - A professora verifica as respostas com a turma, com o objetivo de avaliar a compreensão dos aprendizes e auxiliar a esclarecer alguma dificuldade linguística que os alunos encontrem.

Pre-task 2 - Tarcísio vai ao consulado italiano. Assistir à cena e responder como ele deve fazer para chegar no departamento de retirada de passaportes. Compartilhar a resposta com os colegas e verificá-la. O objetivo desta atividade é estimular a interação entre os alunos para construírem juntos a resposta e identificar itens linguísticos úteis para pedir e dar informações de direção.

During task 2 - Observar o mapa, escolher um lugar onde quer ir e pedir informações para o colega que deverá dar as direções. Ouvir e desenhar no seu mapa as direções indicadas.

Post-task 2 - A professora visita cada grupo verificando a realização da tarefa e esclarecendo dificuldades linguísticas encontradas pelos alunos. In plenum, com toda a classe, a professora destaca as questões linguísticas comuns encontradas pelos grupos, construindo com os alunos a explicação das perguntas que surgiram durante a realização das tarefas. 


\section{Chi ha lingua va a Roma}

Dire, Fare, Partire! - Video Lezione 8 - parte 1

http://eaulas.usp.br/portal/video.action?idltem $=5779$
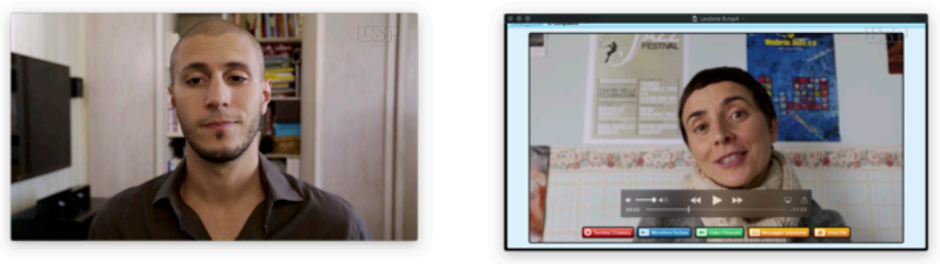

\section{Attività 1}

In copia, guardate le scene indicate chi dice ogni frase: Tarcisio (T) o Elisa (E)

(3:45-6:46)

( ) ho messo un aeroplanino che passa

( ) o non li vedrà mai più

( ) mandami le foto

( ) oggi sento quasi la mancanza di una routine

( ) dopo le follie del viaggio e del trasloco

( ) avevi una sorpresa per me

( ) sono state scritte dalla sua sorella più piccola, che è rimasta a Picerno

( ) parla sempre di un tale signor C

( ) scusa, adesso devo uscire

( ) vuol dire che hai anche la cittadinanza

( ) in bocca al lupo per il consolato

( ) ci vediamo

\section{Attività 2}

Guardate ancora una volta e rispondete: di quali argomenti parlano Tarciso e Elisa? Scrivete una lista.

\section{Attività 3}

Tarcisio è al consolato. Guardate il video e rispondete come arrivare all'ufficio dove ritirare il suo passaporto. Attenzione alle espressioni usate per indicare direzioni.

Figura 5 - Folha de atividades da tarefa pedagógica Chi ha lingua va a Roma (página 1) 
Attività 4

In copia, guardate la cartina di Bologna. Siete davanti al Grand Hotel Majestic. Uno di voi sceglie un posto dove andare e chiede informazioni. L'altro collega dà le indicazioni per arrivarci.

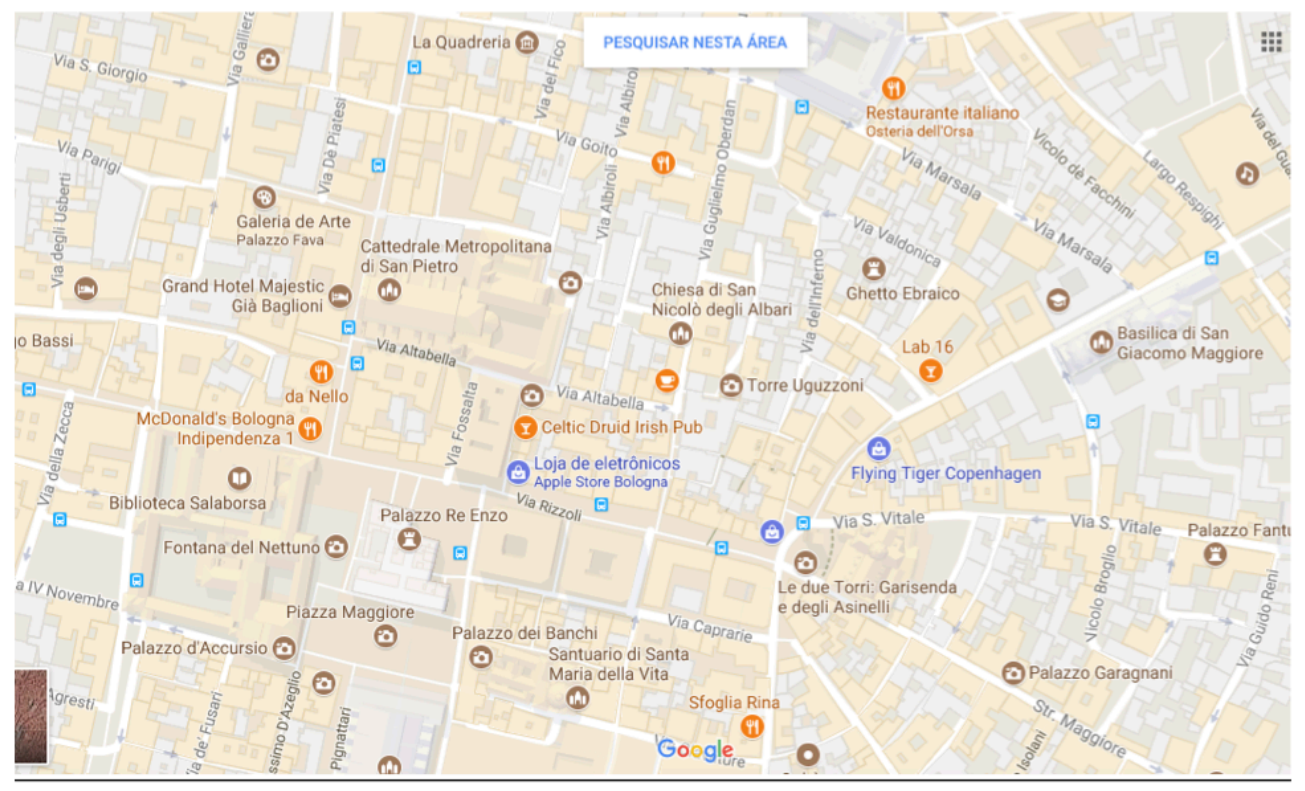

Figura 6 - Folha de atividades da tarefa pedagógica Chi ha lingua va a Roma (página 2) 


\subsection{Análise da interação entre os aprendizes durante a tarefa Cercando Lavoro}

\subsubsection{Monitor $e$ feedback positivo}

Conversando a respeito dos interesses de Tarcísio, G reformula seu enunciado (T1 e T3) buscando vocabulário e estrutura mais adequados e $\mathrm{V}$ oferece feedback positivo confirmando a informação de que Tarcísio pensa em continuar trabalhando como jornalista (Tabela 1).

Tabela 1 - Uso de monitor e de feedback positivo

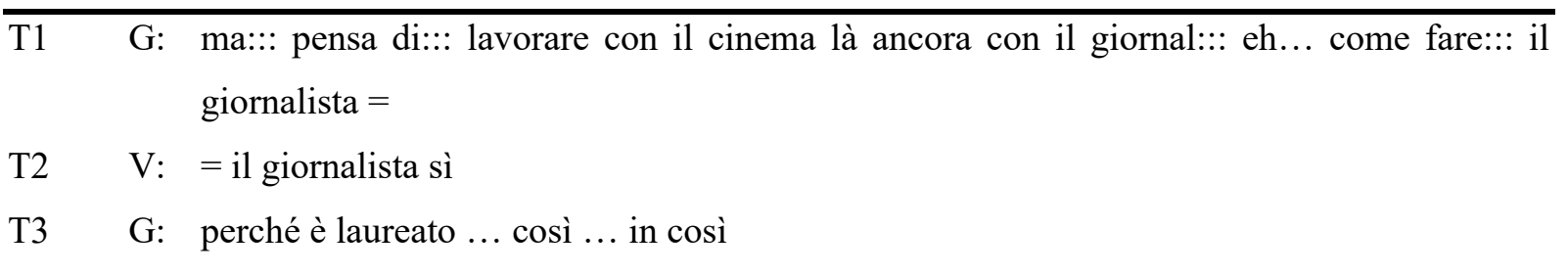

Observa-se um exemplo de monitoramento pessoal quando $G$ reformula a própria frase (T2), corrigindo a forma da preposição di por dei (Tabela 2).

Tabela 2 - Uso de monitor para correção de item linguístico

\begin{tabular}{llll}
\hline T1 & V: & vestirsi be:::ne::: & ((escrevendo)) \\
T2 & G: & ah di- dei consigli ? & \\
T3 & V: & sì & \\
\hline
\end{tabular}

\subsubsection{Andaime (scaffolding)}

Os aprendizes procuraram auxiliar o colega a formar as sentenças, provendo andaimes. Na tabela 3, pode-se ver dois momentos em que R oferece auxílio a G (T2 e T4): após o prolongamento do som eh (T1) e após a segunda pausa (T3), indicando que G estava buscando formular o enunciado.

Tabela 3 - Emprego de andaime (scaffolding)

T1 G: ma::: prima::: eh:::

T2 R: gli interessi ? = 
T3 G: = bisogna parlare sugli interessi di Tarcisio ? Perché eh::: lui vuoe mollare tutti qua e::: andare all'Italia per ... vivere ...

T4 R: vivere là, no ?

T5 V: sì

\subsubsection{Distribuição de turno e feedback negativo}

Após responder uma das perguntas, $\mathrm{G}$ faz uma distribuição de turno, convidando $\mathrm{V}$ a compartilhar as informações que compreendeu da atividade seguinte, listar os conselhos que Marcelo dá a Tarcísio (T1 e T3), na tabela a seguir.

Tabela 4 - Distribuição de turno e feedback corretivo

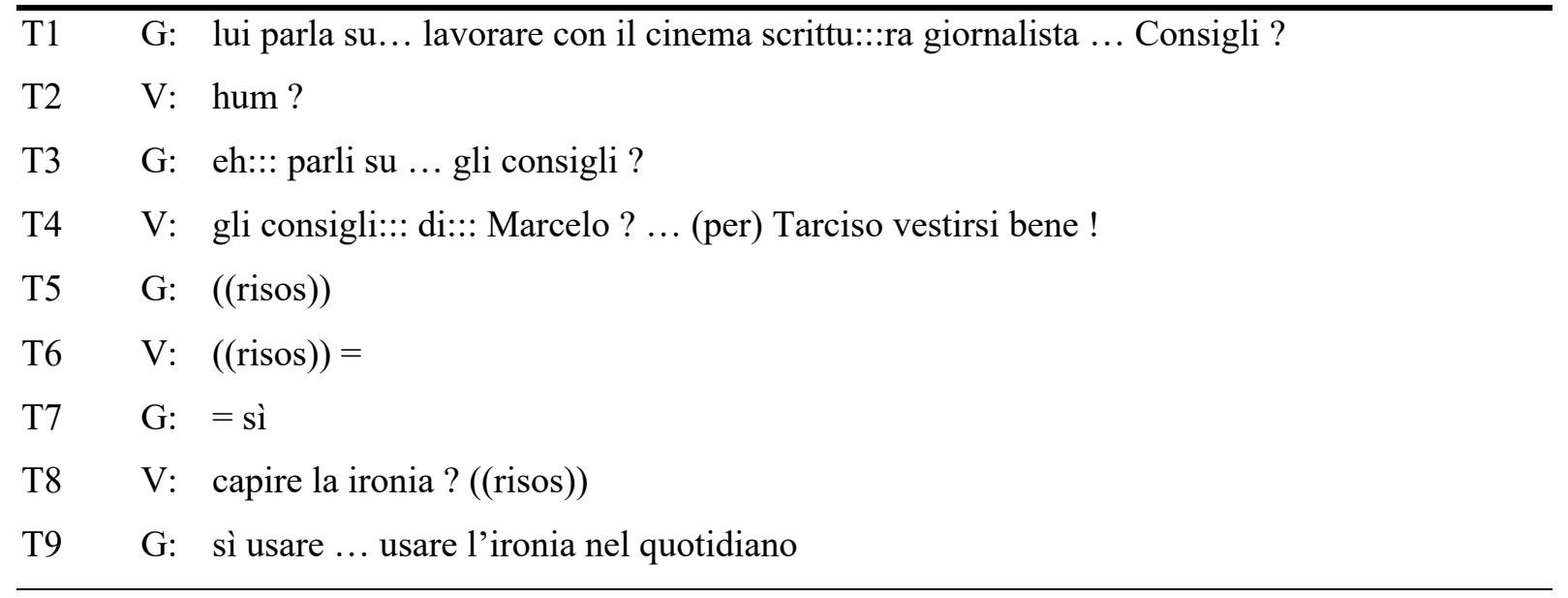

No exemplo da Tabela 4, pode-se observar ainda que G usa uma forma inadequada do artigo masculino em gli consigli (T3), V não percebe o equívoco e usa a mesma forma (T4). Neste caso, o uso inadequado de um artigo não compromete a compreensão e a conversa segue seu fluxo natural, focada na transmissão do significado. Os artigos em italiano, por serem bem distintos do português, são um ponto de dificuldade dos aprendizes brasileiros e podem ser focalizados pelo professor, na medida em que os exemplos ocorram na interação com os alunos, o chamado foco na forma (LONG, 2015).

Dando sequência à interação (Tabela 4), surge um exemplo de feedback corretivo, uma reformulação: V compartilha uma informação que compreendeu do vídeo, mas não tem certeza, o que é demonstrado pela entonação ascendente (T8). G confirma que a informação está correta e oferece feedback corretivo (T9), uma reformulação enfatizada com uma pausa seguida da repetição do termo corrigido (usare ao invés de capire), do uso do artigo adequado 
para a palavra ironia (l'ironia ao invés de la ironia), e faz uma expansão do enunciado com a expressão nel quotidiano (no cotidiano), em T9.

\subsubsection{Aprendizagem colaborativa: construindo o significado}

Em seguida, V continua compartilhando informações e ainda revela incerteza, buscando confirmação através da entonação ascendente (T1). G confirma a informação e compartilha outras duas (T2). Nota-se que G prolonga o som final em portare (T2) e R provê a parcela a tavola (T3), em um andaime, complementando o enunciado junto com o colega em uma sobreposição de turnos (Tabela 5).

Tabela 5 - Construção colaborativa de significado

\begin{tabular}{lll}
\hline T1 & V: & studiare la tradizione italiana $?$ \\
T2 & G: & sì, fare attenzione nel clima::: come si portare::: $=$ \\
T3 & R: & $=$ a tavola \\
T4 & G: & $=$ a tavola
\end{tabular}

\subsubsection{Aprendizagem colaborativa: ampliando o léxico}

No estudo individual, os aprendizes podem contar com o uso de um dicionário para checar a tradução ou a sinonímia de uma palavra. Mas no estudo em grupo, em que ocorrem trocas a respeito do tema, há uma experiência de uso da palavra em questão, o que pode se revelar como um facilitador de aquisição da LA.

No exemplo a seguir (Tabela 6), V parece querer confirmar como se diz clima. $\mathrm{G}$ pensa que é clima mesmo (T4), mas pede uma confirmação a V. Este confirma (T5) e G compartilha uma outra palavra, stagione (estação), que está no mesmo campo semântico de clima (T6). E, finalmente, $\mathrm{V}$ repete a palavra, demonstrando interesse em utilizar o termo apresentado por G (T7).

Tabela 6 - Aprendizagem colaborativa: ampliando o léxico

\begin{tabular}{lll}
\hline T1 & V: & ((inc) $)$ \\
T2 & G: & clima? \\
T3 & V: & ((inc)) (acho que::: $)(($ inc $))$ \\
T4 & G: & clima clima ... clima né ?
\end{tabular}


T5 V: clima clima

T6 G: clima clima ! ... stagione

T7 V: stagione

Buscando em um dicionário português-italiano, ou em uma ferramenta de tradução online, pode-se encontrar a confirmação de que a palavra é a mesma nas duas línguas. Neste exemplo, por outro lado, o trabalho em grupo propiciou a oportunidade de ampliação lexical com o compartilhamento de um termo que o aprendiz não encontraria naquele verbete (stagione).

\subsubsection{Aprendizagem colaborativa: expressando as próprias opiniões}

A partir da pergunta "A língua seria um fator decisivo para encontrar trabalho?" proposta na folha de atividades, G pergunta ao grupo, distribuindo o turno de fala aos colegas: "Vocês pensam que o conhecimento de uma língua é importante para encontrar trabalho? De uma língua? Qual?” (T1). É interessante notar que G não leu a pergunta simplesmente, mas procurou expressá-la com outras palavras, a partir de sua compreensão, como pode-se observar na tabela a seguir.

Tabela 7 - Aprendizagem colaborativa: expressando as próprias opiniões

T1 G: Pensate che la::: conoscenza di una lingua è importante para per ... trovare lavoro? ... Di una lingua ?... Quale ? ((risos)) $=$

$\mathrm{T} 2 \mathrm{~V}:=(($ risos $))=$

T3 R: $=(($ risos $))$

T4 G: l'inglese forse? $(($ risos $))=$

T5 V: $=(($ risos $))$ l'inglese

T6 G: $=(($ risos $))$

T7 R: ((inc)) una lingua è importante::: $=$

T8 $\mathrm{V}:=$ sì

T9 R: oggi::: la lingua::: è un (differenciale) TF

T10 G: sì

T11 R: alcuni::: alcuni::: vezes ((em voz baixa)

T12 G: volte $=$

T13 R: = (volti) TF ... non se::: non è bisogno ... la lingua (pero) ES eh::: è un (gifferenziale) $\mathrm{TF} \ldots=$ 
T14 G: = sì

T15 R: un differenziale

Na tabela 7, notam-se também elementos que evidenciam o foco na forma: a ação do monitor (KRASHEN, 1981) na ocorrência de um lapsus, uso da L1 por distração seguido de autorreparação (FERRONI, 2012), dos termos "para" e per (T1); o uso de andaime na construção da expressão alcune volte (T11-T13) em que $\mathrm{G}$ oferece a R a palavra que buscava (R diz "vezes" em voz baixa e G diz a palavra em italiano, volte); e uma construção lexical em que $\mathrm{R}$ diz que mesmo não sendo necessário para uma determinada vaga de trabalho, o conhecimento de uma língua estrangeira hoje em dia é um diferencial. $\mathrm{R}$ experimenta a pronúncia da palavra de duas maneiras, em que se pode notar transferência fonética em differenciale (T9) e em gifferenziale (T13), chegando à pronúncia adequada, differenziale (T15). Interessante notar que os colegas não interrompem R e que durante a interação, com o uso do monitor, ele chega à pronúncia adequada.

\subsubsection{Troca de código e negociação de significado}

Na Tabela 8 podemos ver exemplos de troca de código, o uso da LM como ferramenta de apoio na comunicação em sala de aula: V pergunta como se diz "área” em italiano (T1), para se referir à área de trabalho de Tarcísio (T2); G se surpreende com a pergunta (T2) e incentiva $\mathrm{V}$ a continuar se expressando (T4). Fazendo uso de um andaime, G sugere o emprego do termo complessivo (T6) após uma hesitação de V marcada por prolongamento e longa pausa (T5) e pergunta se o termo que buscava era "global" (T6), o que V finalmente confirma.

Notam-se ainda algumas inadequações (tutti $i$ mundi, dei notizie) que não são reparadas (T10-T12): nesse momento a atenção dos aprendizes não está na forma, mas na transmissão da mensagem e na negociação do significado (Tabela 8).

Tabela 8 - Troca de código

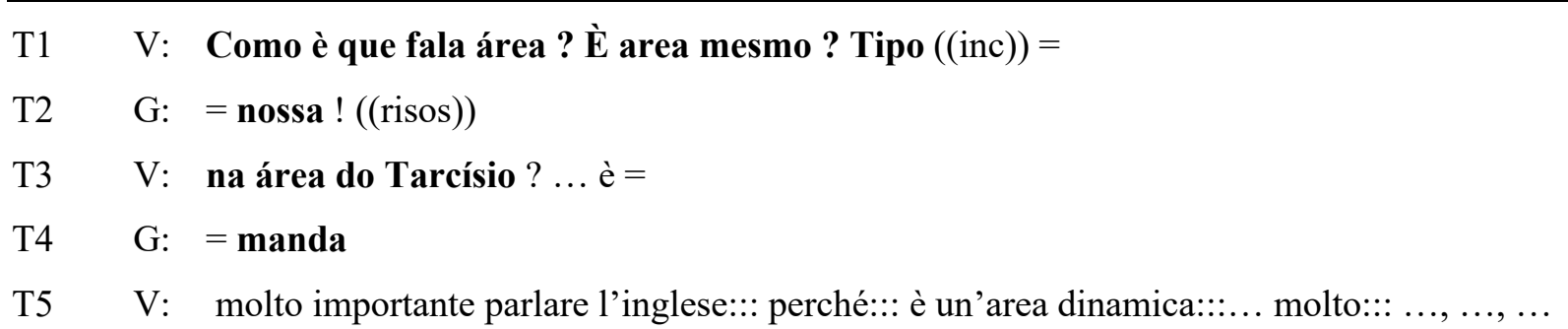




$$
\begin{array}{lll}
\text { T6 } & \text { G: } & \text { complessivo ! diciamo ... complessivo::: global ? } \\
\text { T7 } & \text { V: } & \text { sì::: } \\
\text { T8 } & \text { G: } & \text { complessivo } \ldots \text { deve- deve stare::.: ... deve rimanere:.: in contatto con con = } \\
\text { T9 } & \text { V: } & =\text { sì } \\
\text { T10 } & \text { G: } & \text { tutti i mundi... con }= \\
\text { T11 } & \text { V: } & =\text { le notizie } \\
\text { T12 } & \text { G: } & \text { dei notizie che::.: succedono }
\end{array}
$$

Dando continuidade à conversa anterior, na Tabela $9, \mathrm{R}$ participa do debate dizendo que acredita que todas as profissões que usam a pesquisa precisam do inglês, pois há uma quantidade maior de materiais nessa língua. Na elaboração do enunciado, $\mathrm{R}$ também usa a L1 como apoio e pode-se perceber a ação do monitor na autorreparação de lapsi como: “toda"/tutte (T13), "inglês"/inglese (T16, T18), "mais"/più. Em T13 usa a LM, "pesquisa", para confirmar o significado de ricerca.

Tabela 9 - Troca de código, monitoramento pessoal e aprendizagem colaborativa

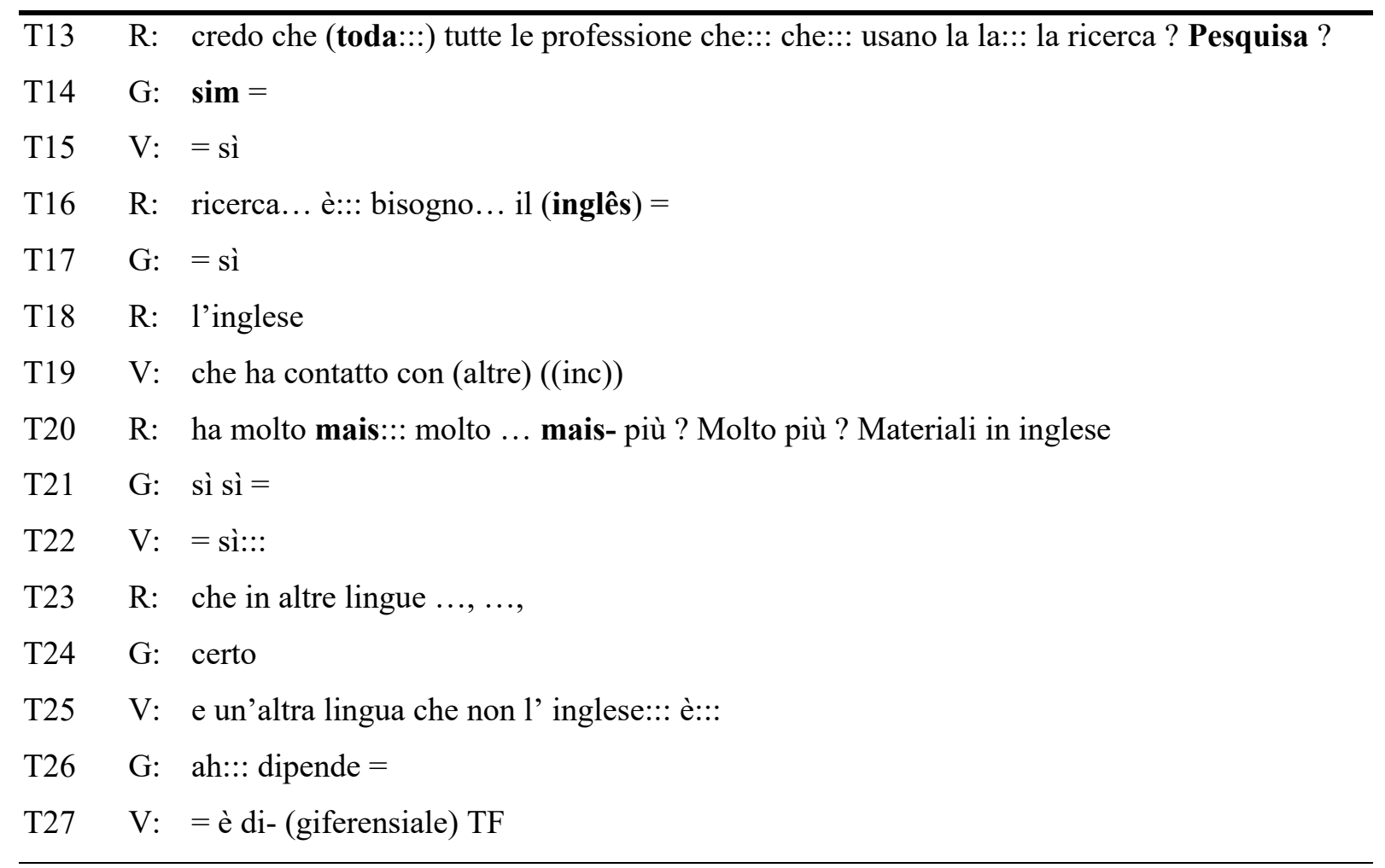

Em T27 observa-se que $\mathrm{V}$ procura fazer uso da palavra differenziale, trazida anteriormente por $\mathrm{R}$ (Tabela 7 - T15), retomando a opinião expressa pelo colega para a 
discussão e revelando um indício de que um aprendiz, ao participar de uma interação, também possa se beneficiar da produção dos colegas no trabalho em grupo (DONATO, 1994).

\subsubsection{Atos de identidade (ironia) e troca de código}

Na Tabela 10, G lê a pergunta da atividade (T1) e compartilha sua opinião, em uma autosseleção de turno. Ocorrem atos de ironia: V parece achar interessante a sugestão de G, de que Tarcísio poderia dar aulas de português na Itália; todos riem, talvez por considerar inusitado que falar o português possa ser um diferencial para se encontrar trabalho (T2-T8).

Depois de uma pausa, G convida os colegas a compartilhar suas ideias (heteroseleção de turno), ocorre uma pausa longa, indicando que os colegas não tinham uma sugestão para compartilhar (T8). Então G, retomando o turno, faz uma segunda sugestão: que Tarcísio poderia trabalhar como jornalista esportivo, pois brasileiros e italianos gostam muito de esporte, comentário que revela o conhecimento de um aspecto intercultural.

Nota-se uma transferência fonética, portughese (T1) que é autorreparada alguns turnos depois (T6) e uma troca de código para gerenciar a conversação com o uso do marcador discursivo "né", onde em italiano se usaria no (T8), na sequência da autorreparação noi/a noi, mostrando que $\mathrm{G}$ busca confirmação dos colegas de que a forma foi corrigida adequadamente.

Referindo-se aos italianos, G diz que eles gostam muito de futebol também (T12), usando a estrutura da LM e palavras da LA (em italiano seria anche a loro piace molto il cálcio), em um caso de transferência fonética.

Tabela 10 - Ato de identidade (ironia), lapsi autorreparados, uso do monitor

T1 G: Che tipo di lavoro pensate sarebbe più adatto per Tacisio Tarcisio in questo momento e perché? ..., Hum::: allora penso che sia una::: buona indicazione fare::: 1' insegnante di (portughese) TF quando::: = [continua]

T2 V: $=$ hum::: ((risos)) [continuação]

T3 G: arrivare in Italia $(($ risos $)) \ldots$ non so se non so se::: hai qual- qualche interesse $(($ risos $))=$

T4 $\mathrm{V}:=(($ risos $))$

T5 R: $=(($ risos $))$

T6 G: imparare portoghese là ... ma::: è un' opizione una::: =

$\mathrm{T} 7 \quad \mathrm{~V}:=$ sì:::

T8 G: un differenziale $(($ risos $)) \ldots, \ldots, \ldots$, cosa di più $? \ldots, \ldots, \ldots, \ldots, \ldots, \ldots, \ldots, \ldots, \ldots$, sì ! certo ! fare::: il giornalista ... Forse il giornalista sportivo perché::: penso che::: noi brasiliani:: ... a noi ... né ! ... piacciono::. questi::: = 
T10 G: temi::: sporti::: gli gli italiani anche ... Agli italiani anche Spesso il calcio no!

T11 V: sì:::

T12 G: (a loro piacciono ..., ..., un sacco::: il calcio anche) TF

Observam-se outros atos de ironia (Tabela 11), quando os alunos vão realizar a tarefa de procurar oportunidades de trabalho para Tarciso em um site italiano. Os alunos se divertem com o nome do site (infojobs.it), e há troca de código quando brincam dizendo que irão marcar o site como favorito. Ainda conversam em português quando falam da dificuldade de acessar a rede de internet.

Tabela 11 - Ato de identidade (ironia) e troca de código

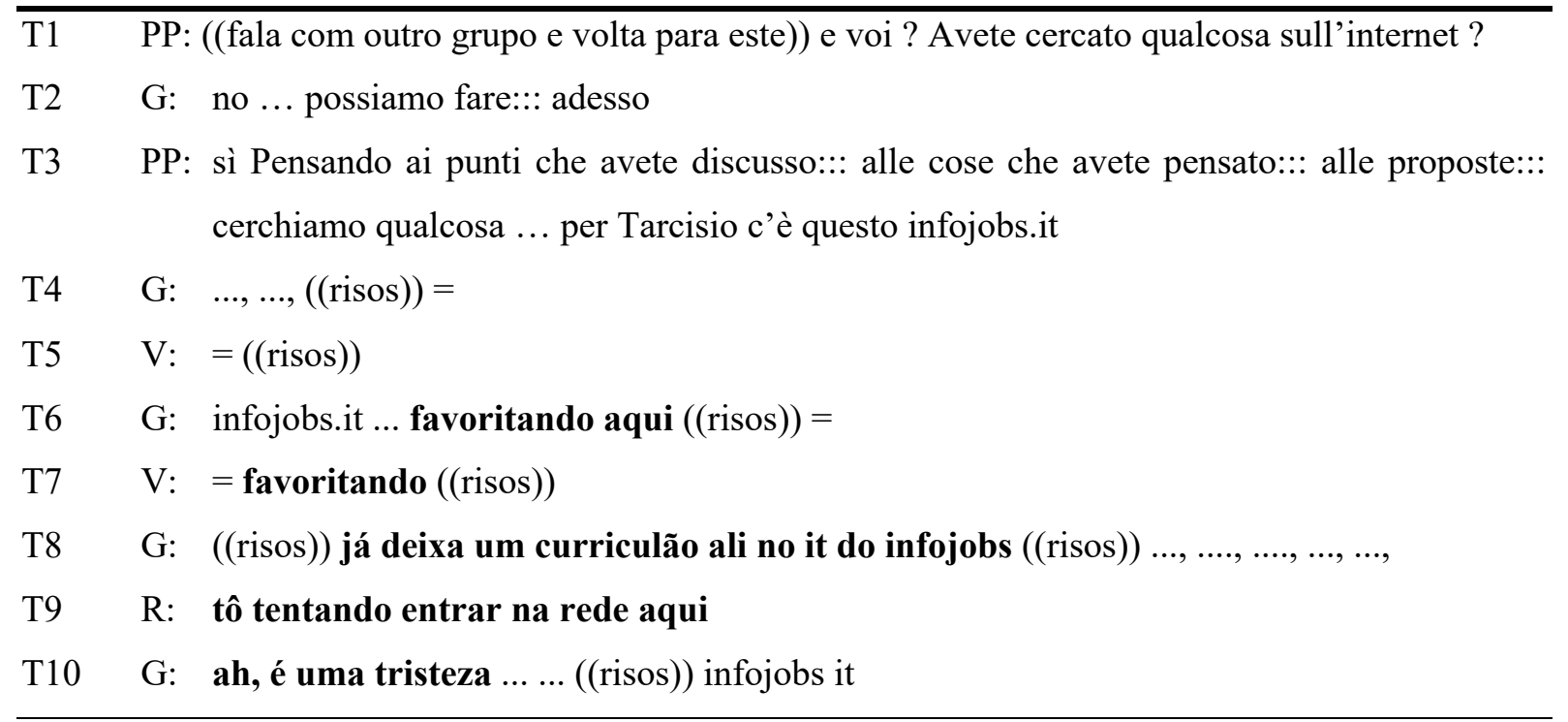

\subsection{Análise da interação entre os aprendizes durante a tarefa $L$ 'abito non fa il monaco}

\subsubsection{Distribuição de turno, atos de identidade (ironia), troca de código, monitoramento}

Após assistir ao vídeo da primeira atividade, os aprendizes respondem à primeira pergunta proposta na folha de atividades: “segundo Marcelo, como se vestem os italianos?". $\mathrm{G}$ convida $\mathrm{F}$ a responder (T1), usando o termo ascolti (escuta) ao invés de senti, e reformula pergunta. Aqui, observa-se um lapsus no uso da palavra come que é autorreparada por "como" marcando uma transferência fonética por influência da LM. 
Em seguida, por duas vezes há mudança de código: quando $\mathrm{F}$ usa as palavras "adequado" (T2) e "comprar" (T7) subindo a entonação, em busca do auxílio de G, que prefere não responder ao pedido, e F dá sequência à sua fala (Tabela 12).

Tabela 12 - Distribuição de turno, troca de código e monitoramento pessoal e cooperativo

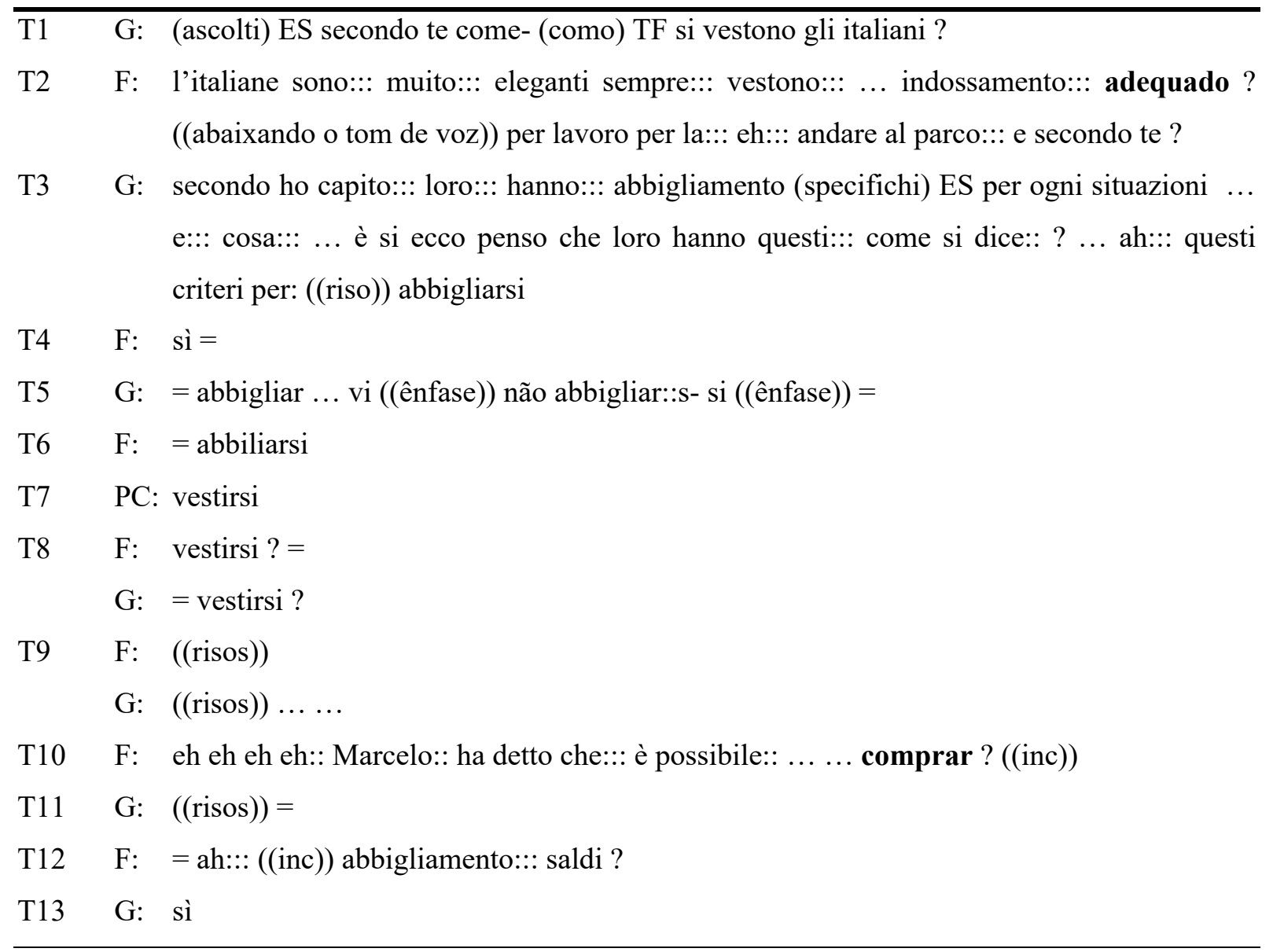

Um exemplo de foco na forma do verbo reflexivo abbigliarsi ocorre com um monitoramento pessoal de G (Tabela 12), que busca a forma adequada do pronome e quando conclui, F confirma a forma adequada, porém rara - um verbo mais frequente seria vestirsi, e é indicado pela professora da classe em uma correção explicita. Os alunos riem, um pouco sem graça, e dão sequência à conversa (T3-T5).

\subsubsection{Monitoramento pessoal, monitoramento cooperativo, feedback negativo e transfer}

Na continuação da conversa (Tabela 13) observa-se monitoramento pessoal com o reparo da forma dove por deve (T15) e monitoramento cooperativo quando G provê feedback negativo na correção da forma plural nuovi (T19), enquanto F havia usado nuovo (T19). 
Há várias ocorrências de transferência da estrutura da LM com palavras da LA: na anteposição do pronome reflexivo, si preoccupare em lugar de preoccuparsi (T15); no uso da preposição, nell'Italia em lugar de in Italia (T15); no emprego do verbo bisogna com a estrutura da LM ("precisa") em lugar de ha bisogno di (T18-T19) e da preposição em si veste di un modo ("se veste de um jeito") em lugar de si veste in un modo (T19).

Tabela 13 - Transferência, monitoramento pessoal e monitoramento colaborativo

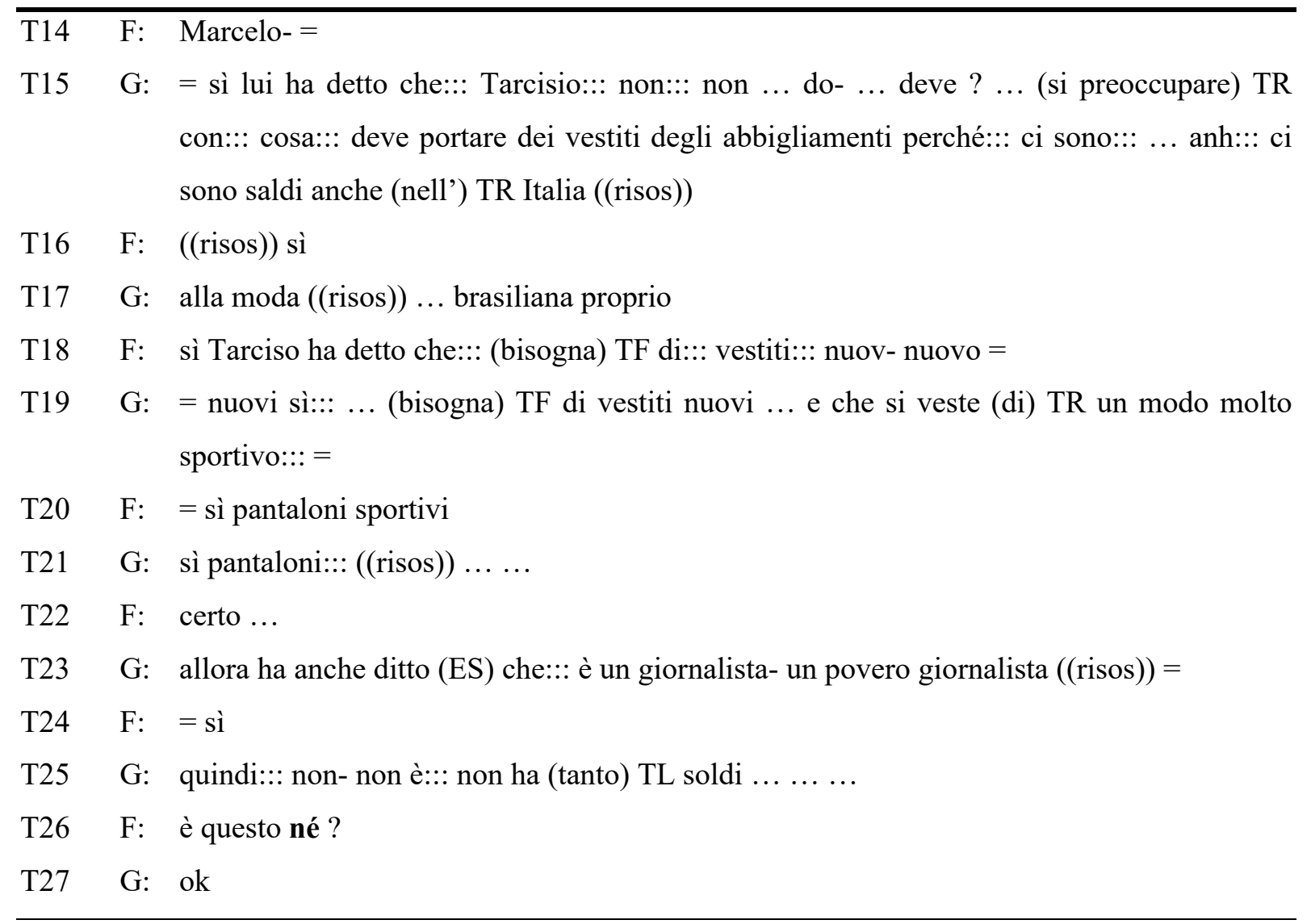

Observam-se, ainda, exemplos de estrangeirismo (T23) no emprego da forma ditto (que quer dizer "dedo") em lugar de ha detto (“disse”) e, finalmente, a mudança de código para gerenciar a conversação com o emprego do marcador discursivo "né" em um pedido de consentimento.

\subsubsection{Trocas de código, estrangeirismo, transferência e transferência fonética}

Terminada a discussão anterior, F lê um tópico na folha de atividades, que transforma em pergunta, e, enquanto aguarda que os outros grupos terminem suas discussões, inicia uma nova conversa (Tabela 14). 


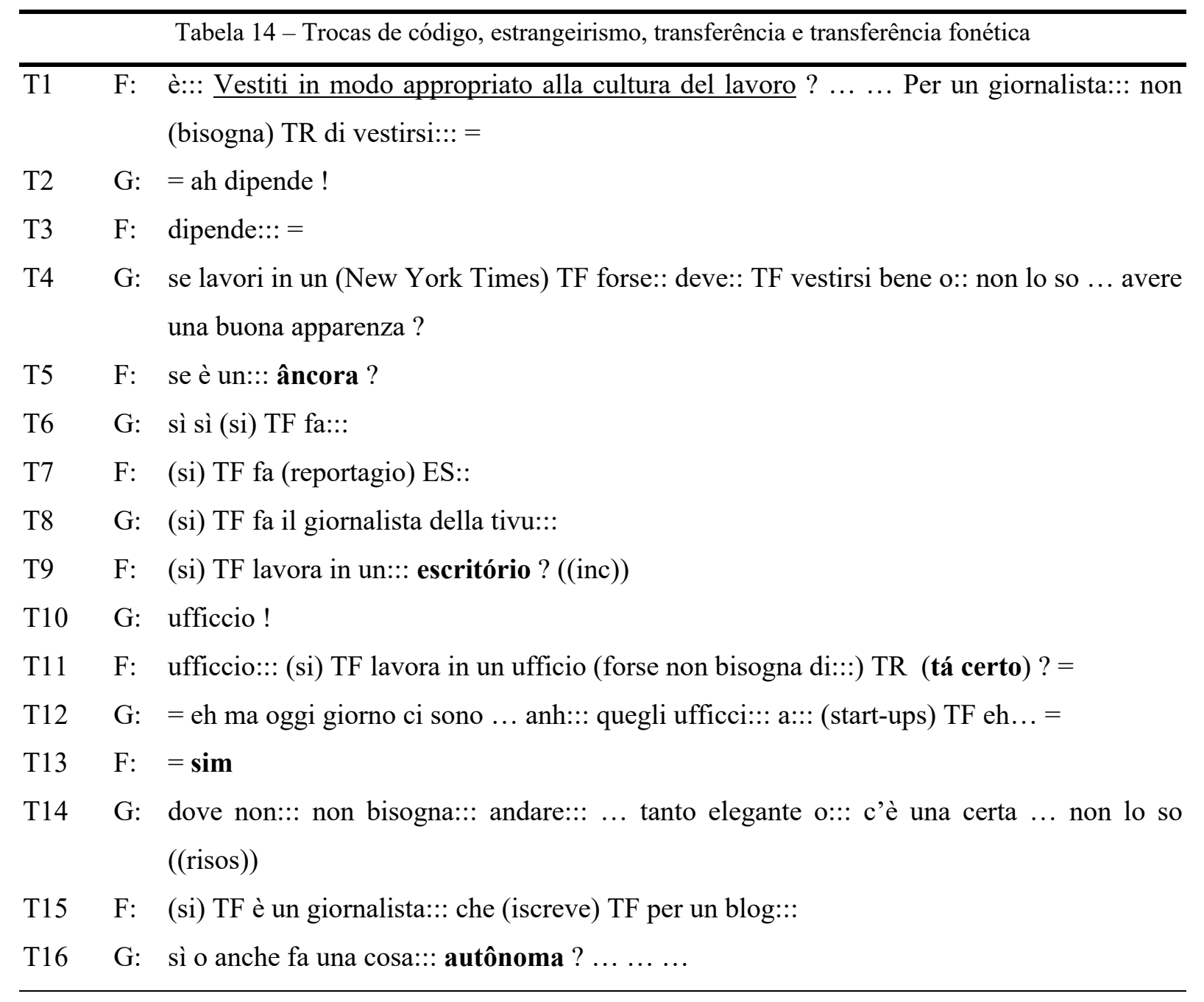

Observa-se novamente a ocorrência de transferência no emprego do verbo bisogna ("precisa") em lugar de ha bisogno (T1) - como o exemplo destacado na tabela 13. Em T11, F pede uma confirmação da transferência forse non bisogna di ("talvez não precise") com a troca não negociada “tá certo?".

Há outras duas trocas de código não negociadas: com o uso da palavra "âncora" em que $\mathrm{F}$ pede auxílio a $\mathrm{G}$ através de entonação ascendente, marcando um pedido de confirmação (T5), mas G dá sequência à conversa, concentrando sua atenção na mensagem que está sendo transmitida (talvez por desconhecer que em italiano se diz reporter); e quando G usa a palavra “autônoma” e pede confirmação a F. Já a troca "escritório" (T9) é negociada e recebe o reparo ufficio (T10), que é confirmado em seguida por F (T11).

Há várias ocorrências de transferência fonética da pronúncia da LM: deve (ele/ela deve) em lugar de devi (você deve) (T4); si (pronome reflexivo "se") em lugar da conjunção se (T6-T9, T11, 15);

F cria um estrangeirismo, reportagio (T7), para a palavra servizio (reportagem). 


\subsubsection{Aprendizagem colaborativa: deduzindo o significado do léxico}

$\mathrm{Na}$ discussão dos textos a respeito de como se vestir em uma entrevista de trabalho (Tabela 15), F pergunta a G o significado da palavra valigetta (T2), que se vale de uma troca de tradução para sugeri-lo (T3) e juntos deduzem seu significado através do foco na forma do diminutivo (valigia, valigetta).

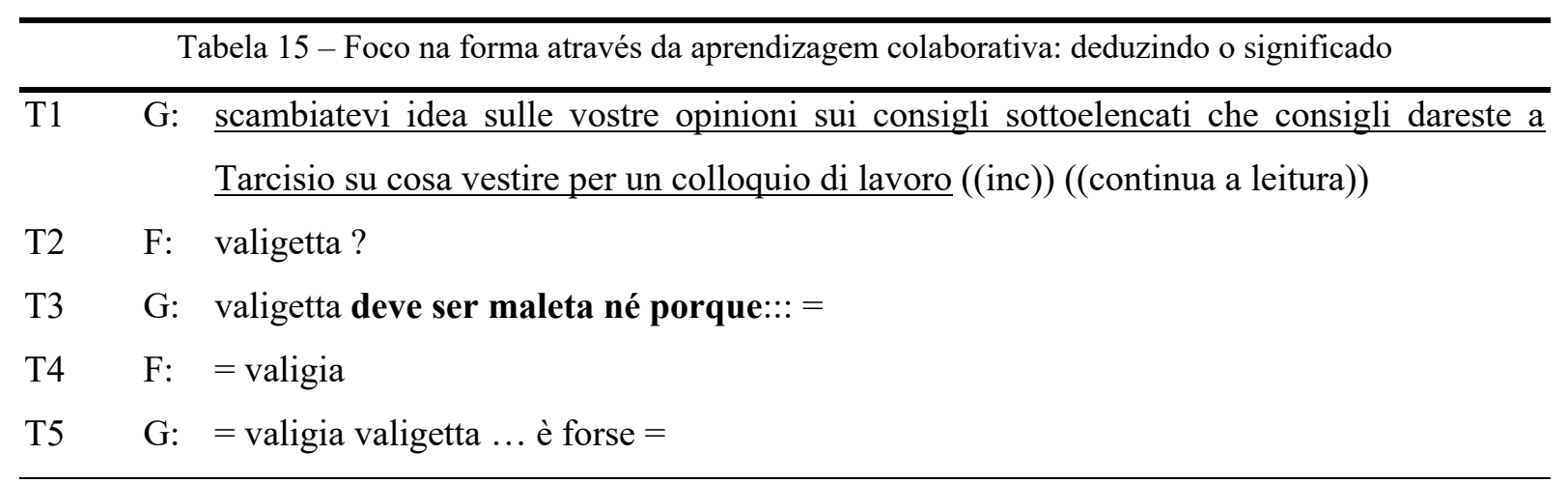

\subsubsection{Troca de código e ato de ironia}

Continuando a leitura, F destaca o último conselho no texto e faz uma brincadeira na LM. Observa-se uma troca de código lapsus, "último", com o autorreparo l'ultimo (T1) e a brincadeira em T5 (Tabela 16).

Tabela 16 - Troca de código e ato de ironia

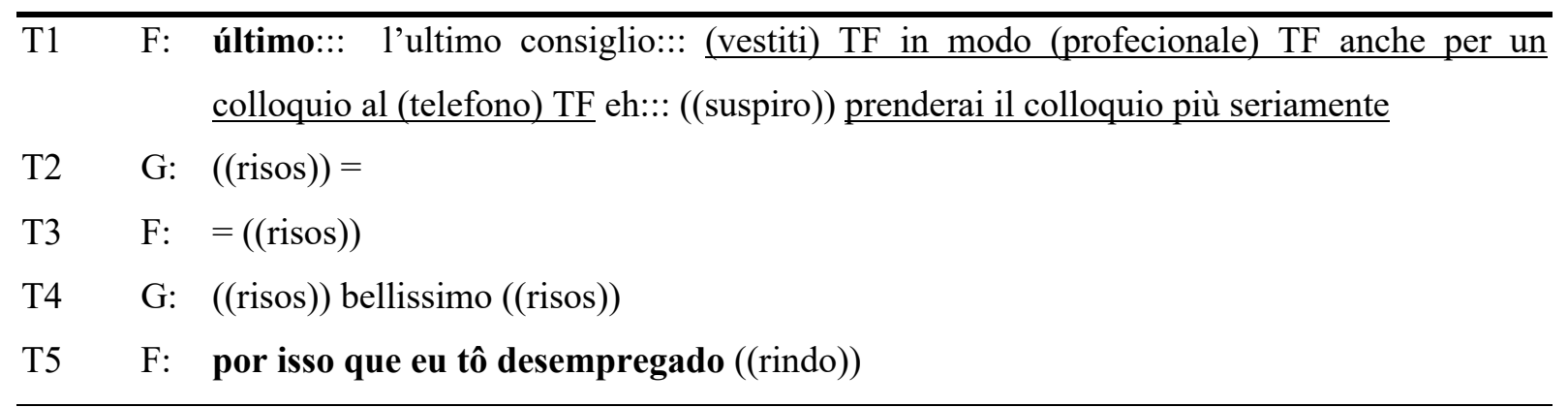

\subsubsection{Foco na forma com monitoramento cooperativo}

Conversando a respeito de conselhos que dariam a Tarcísio, na tabela 17, F pede auxílio na conjugação do verbo querer (volere), através de mudança de código para reflexão metalinguística (T1). 
Tabela 17 - Foco na forma com monitoramento cooperativo

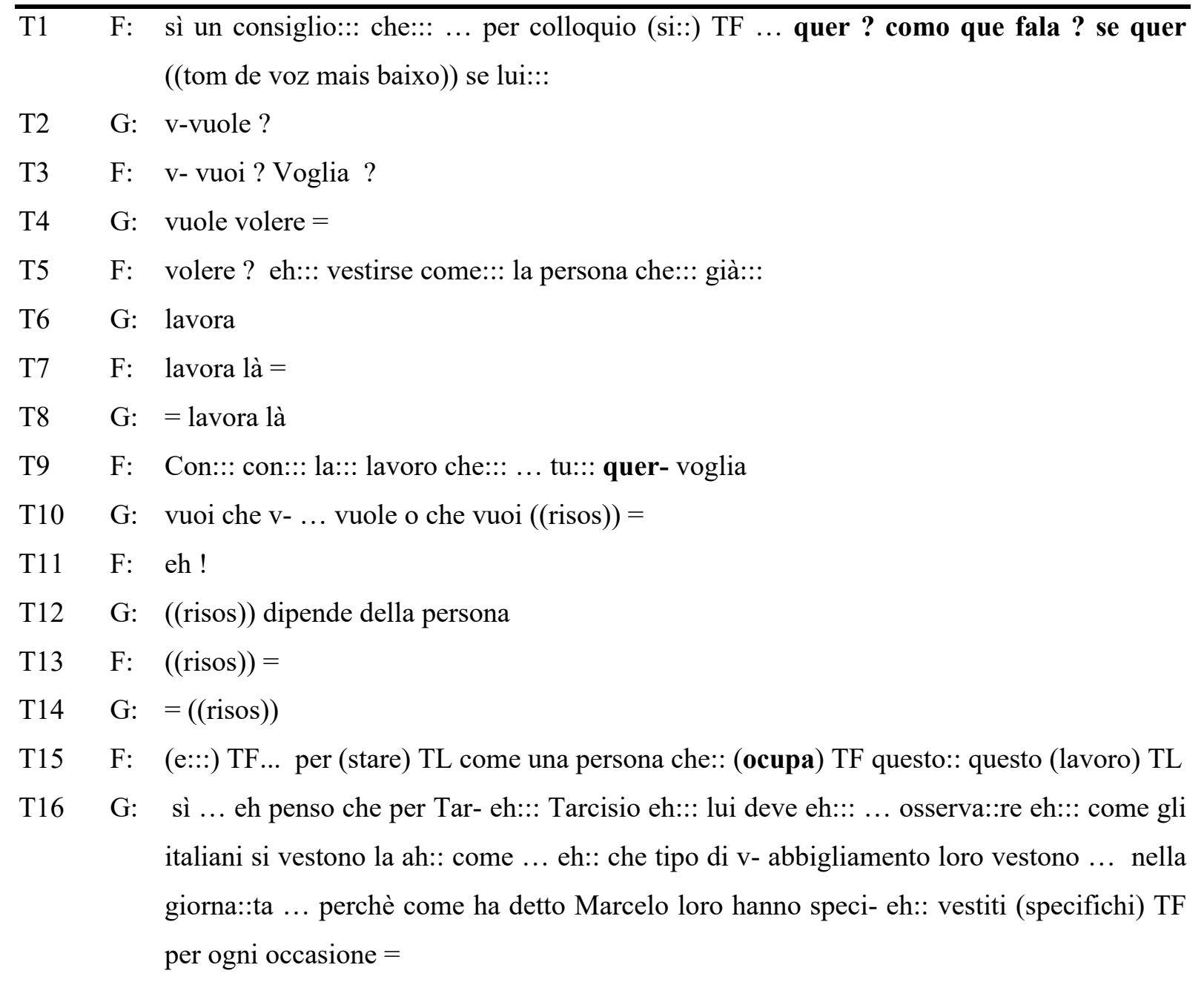

T17 F: $=$ sì

G e F conjugam juntos os verbos (T2-T5, T9-T10), mas F não faz o autorreparo da forma lui vuole, talvez por estar com sua atenção voltada para a mensagem que quer transmitir. Diante da dificuldade, riem (T10-T14). F se vale de duas traduções literais (T15): stare (estar) em lugar de vestirsi e lavoro (trabalho) em lugar de posto di lavoro (local de trabalho).

Observam-se transferências fonéticas, palavras pronunciadas como em português: $\mathrm{F}$ (T15) pronuncia a conjunção $e$ como “i”, o verbo "ocupa” com a tônica na segunda sílaba (em italiano occupa é proparoxítona) e G pronuncia specifichi, por influência da consoante oclusiva palatal [ ki ], chi, como em "específico" [ ko ], em lugar de specifici, oclusiva alveolar seguida da fricativa pós-alveolar [ $\mathrm{t} \int \mathrm{i}$ ], $c i$ (T16). 


\subsection{Análise da interação entre os aprendizes durante a tarefa Ospitalità}

M, que se considera uma pessoa reservada e que prefere aprender uma LE lendo, falou pouco durante as interações em grupo (algumas vezes preferiu fazer a atividade sozinha por escrito), mas durante a interação verbal, ofereceu suporte à fala de $\mathrm{F}$ e fez perguntas também.

\subsubsection{Aprendizagem colaborativa: Foco no significado}

Na realização da tarefa pedagógica de compartilhar com o colega as informações que haviam sido coletadas do episódio da videoaula 7, M interagiu com F (Tabela 18) oferecendo feedback positivo, demonstrando que havia compreendido a mensagem que $\mathrm{F}$ estava transmitindo (T2, T6), oferecendo suporte quando F pedia auxílio (T7-T8, T11-12), compartilhando informações (T14, T20), e quando $\mathrm{F}$ hesitava, provia resposta à sua busca (T18). Na sua fala observaram-se: troca de tradução, usando palavras na LM, "pão" (T14) e "comida" (T20), para trazer agilidade e fazer fluir a conversa; troca de código para refletir sobre a atividade (T10) e transferência fonética na aspiração do R inicial em restaurante.

$\mathrm{Na}$ fala de F, observaram-se as seguintes trocas de código: em reflexões metacognitivas (T3, T13, T17); em pedidos diretos de auxílio e confirmação (T5); para gerenciar a conversação (T9); nas transferências fonéticas cifo (T3), em lugar de tifo, burocracia, em lugar de burocrazia (T11) e "purê", em lugar de purè (T13); aspiração no R inicial em restauranti (T19); o estrangeirismo face em lugar de fà (T19) e a tradução literal no emprego da palavra "sentido", em lugar de senso (T21).

Tabela 18 - Monitoramento cooperativo com foco no significado

T1 F: ok. A chi (telefona) TF Tarcigio ? eh:: mi sembra che::: lui (ha parlato) TR con li suo zi::o ... Angelo zio Angelo mi sembra eh:::che Fabio ... è padre di Tarcigio

T2 M: um-hum

T3 F: non lo so se::: è certo ! eh:: per quale squadra fa il (cifo) TF Tarcigio ? Non lo so mi sembra Juventus perché::: um::: momento ((abaixa o tom de voz)) eh:::=

T4 M: $=$ non lo so

T5 F: lui::: ha detto che l'altra squadra nã::o eh:::: como que se diz ... tão boa quanto la Juve di Torino ...

T6 M: um-hum 
F: mi sembra che che lui fa il tifo per Juve ((suspiro)) eh::: quando comprerà i biglietti Tarcigio eh:: lui ha detto forse fra due mese::: non lo so quale parola

T8 M: (Cerca) TF due mese

T9 F: sì é::: quê mais ? la famiglia di Tarciso (gli) TR potrà ospitare ? no

T10 M: se não ele não taria pedindo

T11 F: non so ... che ah::: ci sono c'è muita::: (burocaci::a) TF e questo:: non potrà ospitare l'ospitare eh::: cosa è peara peara pearà non non ce- non se come si parla $=$

T12 M: = pearà

T13 F: è un pia::to:: veronese, é isso ? eh::: piato veronese é ... sette quali sono gli ingredienti della pearà secondo Marcelo ? ahm... io non capisco:: tutte le parole che:: ele ha detto ... eh però::: lui ha detto che c'è:::: (purê) TF ... qualcosa con burro pane

T14 M: eh molte parole peppe pão::: =

T15 F: = non capito tutto

T16 M: non capisco

T17 F: eh::: quali sono gli ingredienti parárá eh... lui ha detto anche:: che non si trova:: questo piatto::: $=$

T18 M: $=$ in (restaurante) $\mathrm{TF}$

T19 F: in (restauranti) TF che si (face) ES in ca::sa con la fami::glia

T20 M: può essere:: comida:: della cucina ... povera ?

T21 F: sì sì ... q- q- qualcosa::: in questo (sentido) TL

Na sequência da conversa, $\mathrm{M}$ pede auxílio a $\mathrm{F}$ sobre o time de futebol a respeito do qual Tarcísio e Zio Angelo conversam (T1, Tabela 19). Pode-se observar que não havia ficado claro para M e F que Tarcísio fa il tifo (torce) para o Juventus paulistano, um clube no coração da Mooca, bairro conhecido pela presença marcante da cultura italiana onde vivem imigrantes e gerações de seus descendentes. No episódio, Tarcísio diz que o Juventus para o qual ele torce, não é um time tão bom quanto la Juve di Torino, o time homônimo torinês.

Os aprendizes procuram negociar o significado, mas não chegando a uma conclusão, $\mathrm{F}$ pergunta à professora-pesquisadora se Tarcísio falou da Juve de Torino. Ela confirma que sim e, diante do comentário de $\mathrm{M}$, que diz que não entende, convida-os a fazerem juntos a discussão da atividade, vendo que se apresenta um bom momento para a fase post-task de revisão, ampliação da discussão, feedback e avaliação da tarefa com toda a classe. 
Tabela 19 - Foco no significado com troca de tradução, tradução literal, transferência e transferência fonética

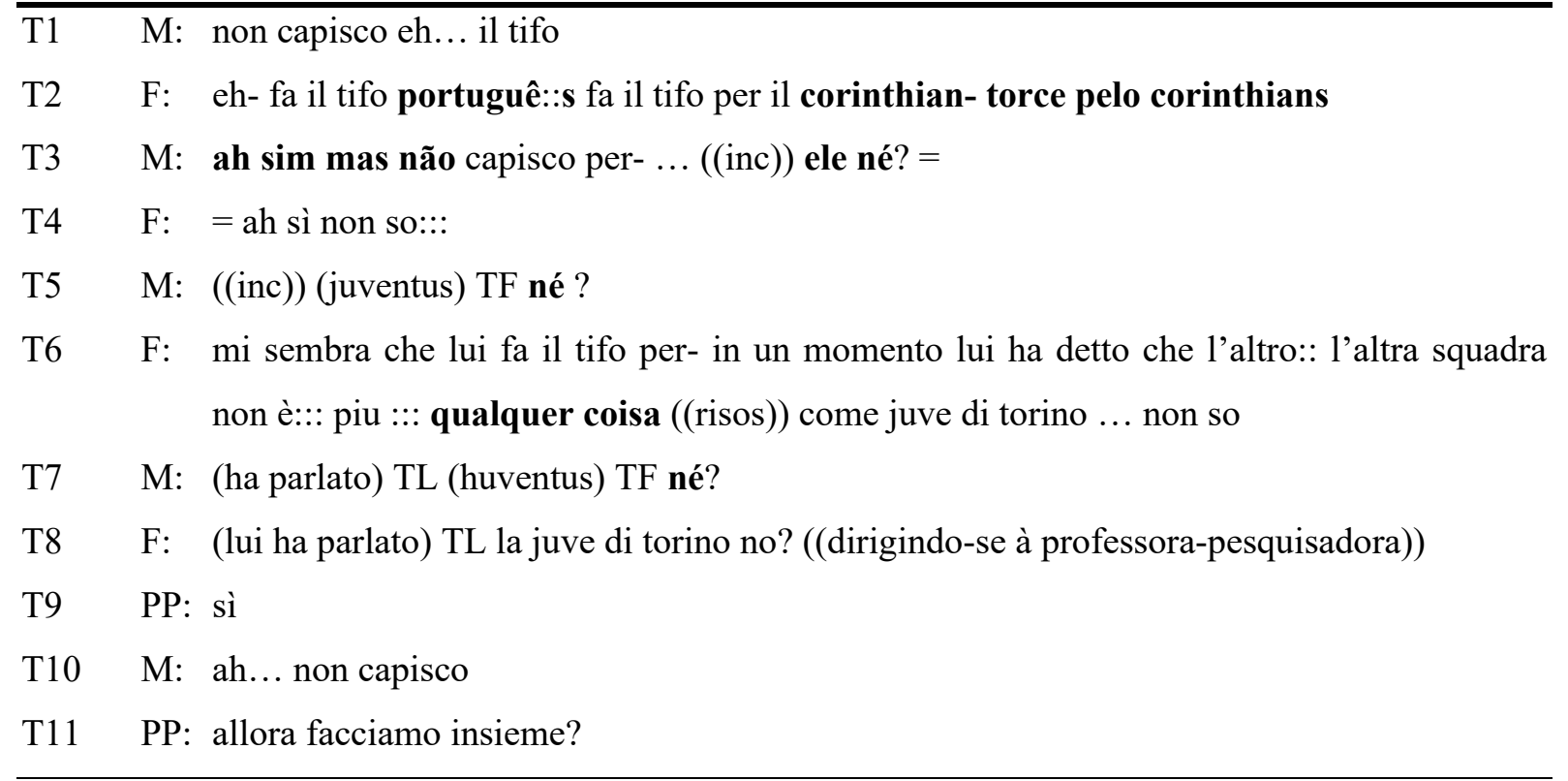

Durante essa interação em que o foco está no significado (Tabela 19), podem-se identificar as seguintes transferências conscientes, utilizadas por M e F como estratégias de comunicação: trocas de tradução para agilizar a fala e fazer fluir a conversa (T2, T3, T6); transferências fonéticas com pronúncia do português em juventus (T5) e pronúncia do espanhol em huventus (T7); traduções literais não negociadas em ha parlato (falou) em lugar de ha detto (T7 e T8); e trocas de código para gerenciar a conversação com o emprego do marcador discursivo "né” (T3, T5, T7).

A atividade pre-task seguinte, assistir ao vídeo de um cozinheiro italiano preparando a Pearà, é de compreensão de um material autêntico, gravado sem fins didáticos. Diante do grau de dificuldade para aprendizes iniciantes compreenderem um nativo, que se expressa com certa velocidade na fala e traços de pronúncia regional marcantes, percebeu-se a necessidade de auxiliá-los na realização dessa atividade. Assim, o procedimento pedagógico (LONG, 2015) escolhido para essa atividade de compreensão foi realizá-la com toda a turma, juntos, pausando o vídeo a cada frase para que todos pudessem ouvir e responder, dentro do tempo necessário para os aprendizes, se as frases na folha de atividades estavam presentes no vídeo ou não. No caso de estarem diferentes, foi pedido que as corrigissem.

Outra dificuldade no uso de materiais autênticos, como esse, é o nível de ruído ambiente, pois trata-se de um vídeo gravado na cozinha de um restaurante durante a preparação do prato. Além disso, o aparelho de som disponível na sala de aula naquele momento apresentou mais ruído do que havia sido percebido anteriormente. 
Após a realização da atividade de compreensão com toda a classe, no formato interativo professora-alunos, o vídeo foi enviado aos aprendizes para que pudessem assistir novamente em casa, e foi dada sequência às atividades com a realização da próxima tarefa na aula seguinte.

\subsection{Análise da interação entre os aprendizes durante a tarefa Mangia che ti fa bene!}

\subsubsection{Aprendizagem colaborativa: foco no significado e foco na forma}

Para retomar a atividade de compreensão realizada na aula anterior, assistiu-se ao vídeo da preparação da Pearà para coletar informações, escrever uma lista de ingredientes e o modo de preparo. Na interação verbal a seguir, G e F compartilham suas informações e escrevem a receita juntos.

Tabela 20 - Aprendizagem colaborativa: foco no significado e foco na forma

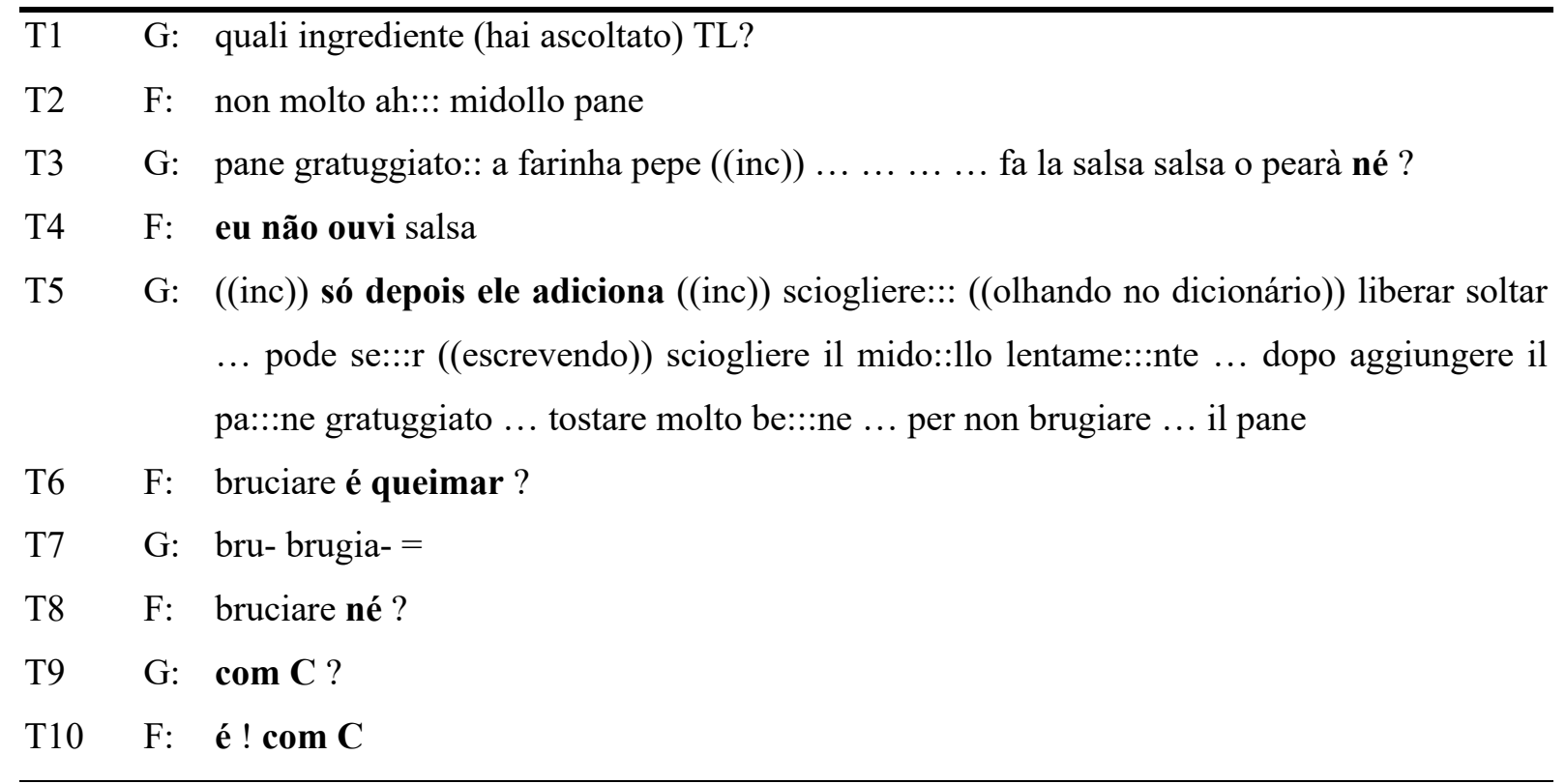

O foco na forma aconteceu durante a escrita em colaboração (Tabela 20): G havia compreendido brugiare (T5), mas F indica a forma adequada, bruciare (T6-T8) e confirma a ortografia “com C" (T10).

As estratégias de comunicação utilizadas nessa interação foram: troca de código para refletir sobre a atividade (T4, T5); para gerenciar a comunicação com o uso do marcador discursivo "né" (T3, T8); para reflexões metalinguísticas, comentários a respeito de léxico 
(T6) e ortografia (T9, T10); e tradução literal, no uso incomum do verbo hai ascoltato (você escutou) em lugar de hai sentito ou hai capito, de uso mais natural em italiano.

\subsubsection{Aprendizagem colaborativa: foco no significado e troca de código}

Na sequência da conversa (Tabela 21), F e G continuaram a troca de informações e a construção colaborativa da receita. Observou-se nova ocorrência da tradução literal ho ascoltato (escutei) em lugar de ho sentito (T22) e de um estrangeirismo (T15), bugliare em lugar de bollire ("ferver, cozinhar"), que não foi reparado.

$\mathrm{G}$ diz que um dos ingredientes que ouviu foi pepe e, pelo contexto, deduz o significado "pimenta", valendo-se da LM para refletir sobre a atividade (T21).

Tabela 21 - Aprendizagem colaborativa: foco no significado e troca de código

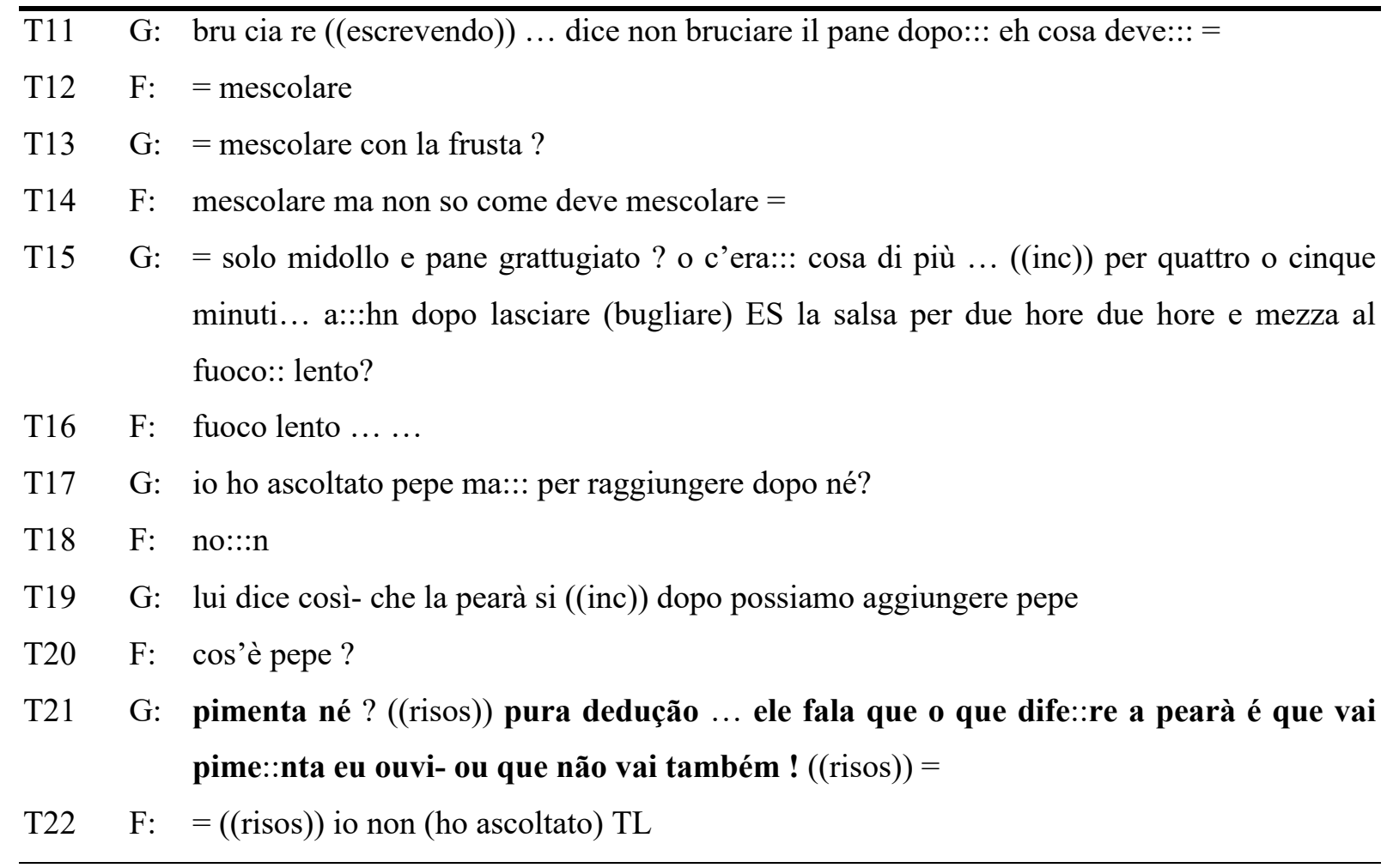

F e $G$ retomam os pontos principais da discussão (Tabela 22). Nesta interação, observam-se as seguintes estratégias de comunicação: troca de código para refletir sobre a atividade (T23, T38-39), para fazer reflexão metalinguística (T24-T25); troca de tradução com o emprego da palavra "baixo", para agilizar e fazer fluir a conversa (T37); tradução literal em aveva parlato ("tinha falado") em lugar de aveva detto (T32); e a criação do estrangeirismo buiare para expressar bollire, "ferver, cozinhar" (T31, T35). 
Tabela 22 - Trasferência consciente como estratégia de comunicação e aprendizagem

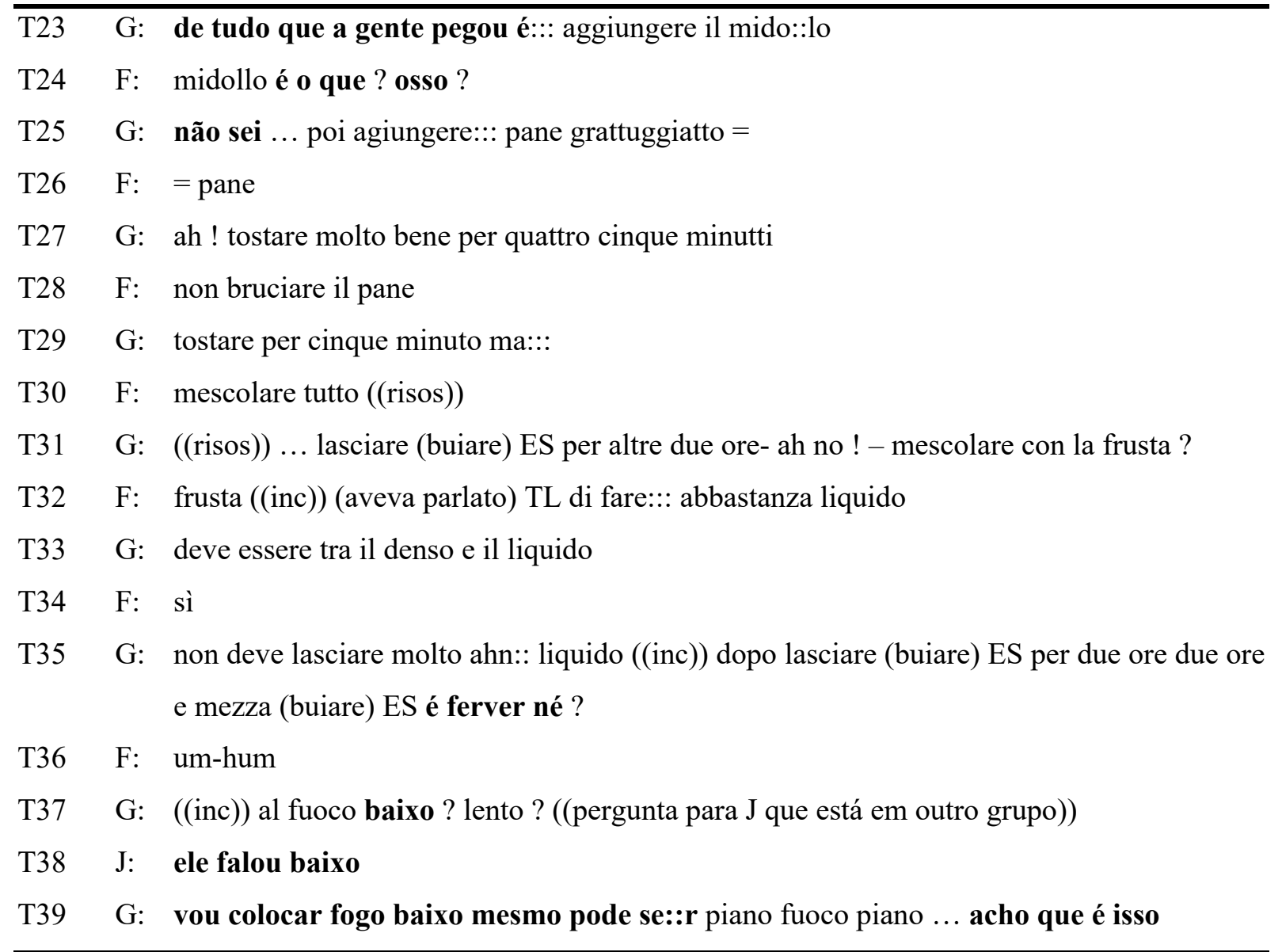

\subsubsection{Post-task: provendo foco na forma através de feedback do professor}

Em seguida $\mathrm{F}$ e $\mathrm{G}$ conversaram em português sobre outros assuntos, relacionados à faculdade. A professora-pesquisadora (PP), percebendo que já haviam concluído a tarefa, veio até o grupo para o post-task com os objetivos de individualizar a instrução (LONG, 2015), dando atenção a cada aluno pessoalmente, ouvir a receita que escreveram e prover feedback (Tabela 23). A PP faz o foco na forma reparando o estrangeirismo buiare por bollire, "ferver" (T14-17), e reparando a transferência fonética em cuocire por cuocere, "cozinhar" (T18-T21). Apenas $\mathrm{G}$ fala sobre o que escreveram, e, no final, a professora pergunta como lhes parece a receita. G diz que provaria e F não, porque não gosta de midollo.

G usa de humor para falar do trabalho do grupo. A PP pergunta como vai a receita deles e G, rindo, responde que está brucciata, "queimada", usando uma palavra que aprendeu com F durante a realização da tarefa (T1-T2). Ela pergunta se precisam de auxílio ou se já terminaram e G responde que estão al punto, “ao ponto” (T3-T4). 
Tabela 23 - Post-task: feedback e foco na forma

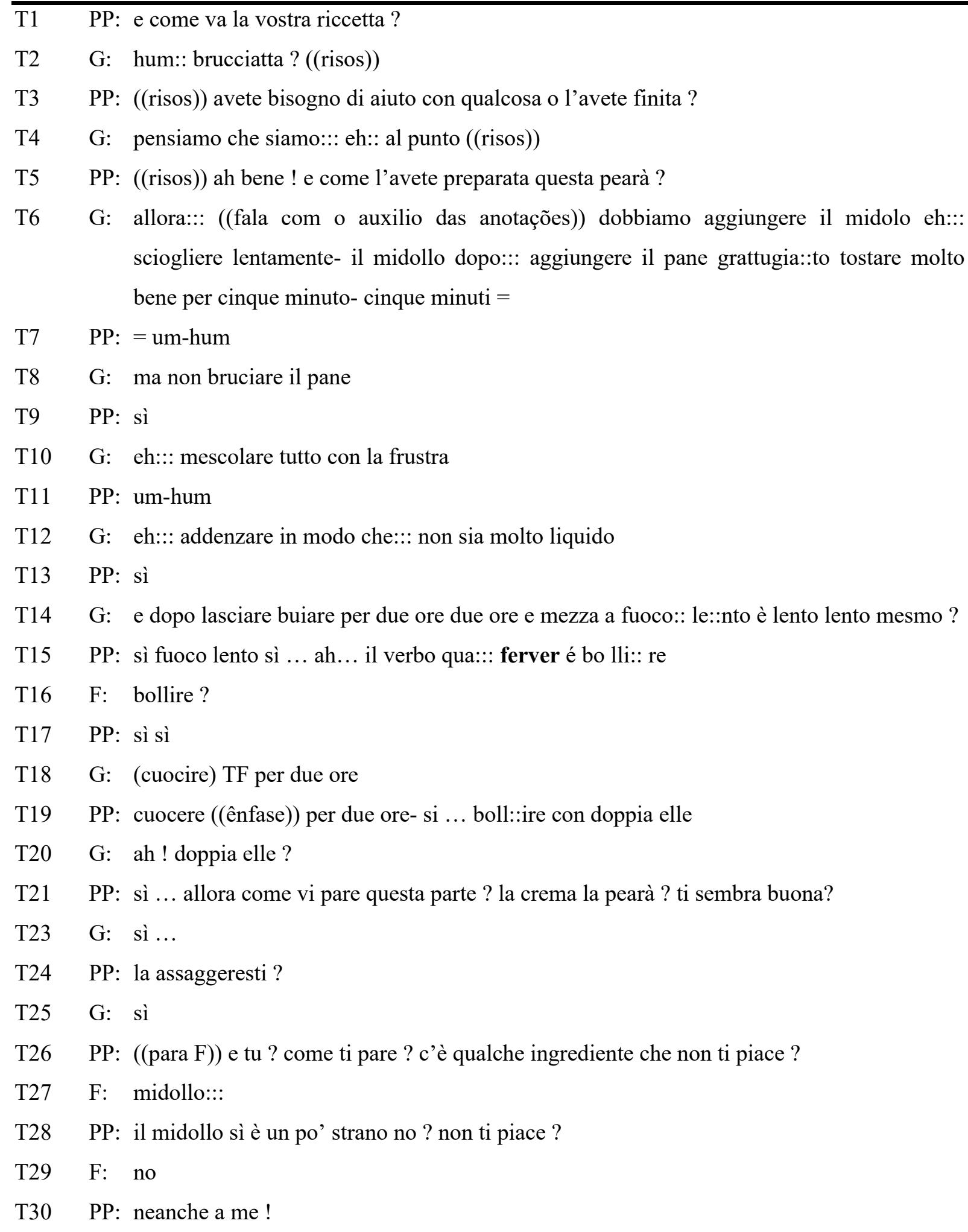




\subsubsection{Aprendizagem colaborativa: foco no significado e monitoramento cooperativo}

A próxima tarefa é criar uma nova receita substituindo ingredientes para uma Pearà brasileira (Tabela 24). F sugere substituir midollo por milho (T3), para manter a mesma aparência da cor amarelada (T5). G prefere manter alguma correspondência nos ingredientes e sugere mocotó (T6). F conta que seu pai o obrigava a comer mocotó e por isso até hoje não gosta.

Durante a discussão, o foco dos aprendizes está na própria conversa, eles se auxiliam e se valem das seguintes estratégias de comunicação: duas tentativas de tradução literal, qualcuna e qualche ("alguma" e "algum"), para expressar a palavra "qualquer" e transferência fonética em correspondenza em lugar de corríspondenza (T4); transferência fonética no uso da palavra mocotó para expressar um ingrediente típico brasileiro; troca de código para conversar sobre o mocotó (T8-T11) e troca de código negociada com o colega, "me obrigava" (T12) seguida de uma tentativa insegura de reparo com a tradução literal obbligava, em lugar de mi faceva (T13).

Tabela 24 - Foco no significado e monitoramento cooperativo

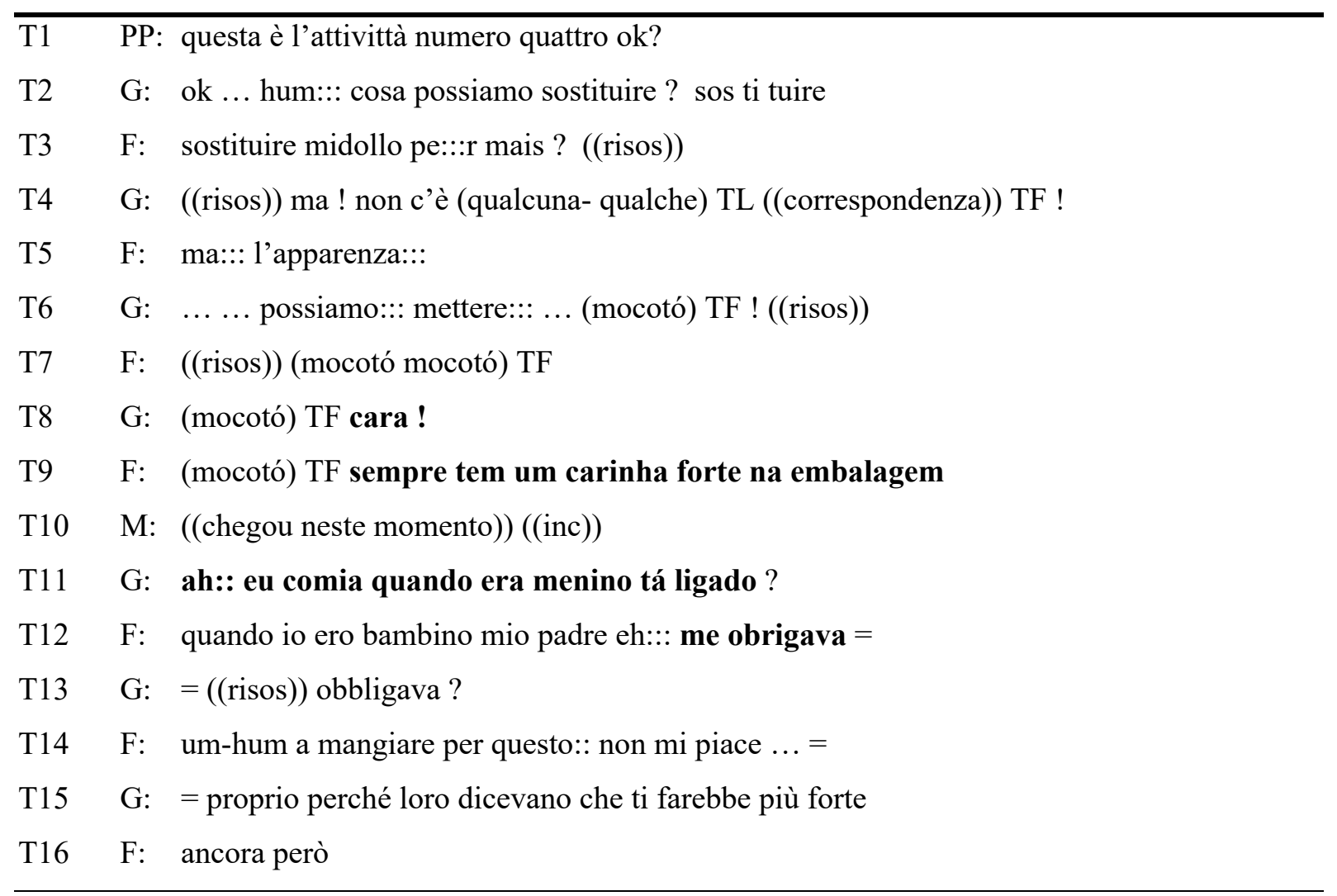


Continuam a conversa em português a respeito de mocotó por alguns minutos e depois retomam a tarefa. G pergunta a $\mathrm{F}$ se concorda em substituir o midollo, por mocotó mesmo não gostando. F concorda e sugere mudar a cor do prato original (que tem uma aparência amarelada) para cor-de-rosa, como o ingrediente brasileiro. Estão na dúvida se seria o mesmo ingrediente, apenas com nomes diferentes, e decidem mudar por mocotó para mudar ao menos a palavra. Para substituir $i$ cotechini, G sugere linguiça toscana, mas F sugere chouriço, por considera-lo mais típico que a linguiça (Tabela 25). Durante essa interação, observa-se uma troca de tradução no emprego da palavra "pata" conferindo fluidez à conversa (T3), a troca de código para reflexões metalinguísticas (T6), para comentar a atividade, na escolha de ingrediente brasileiro, cujo nome não recordavam (T8-T11).

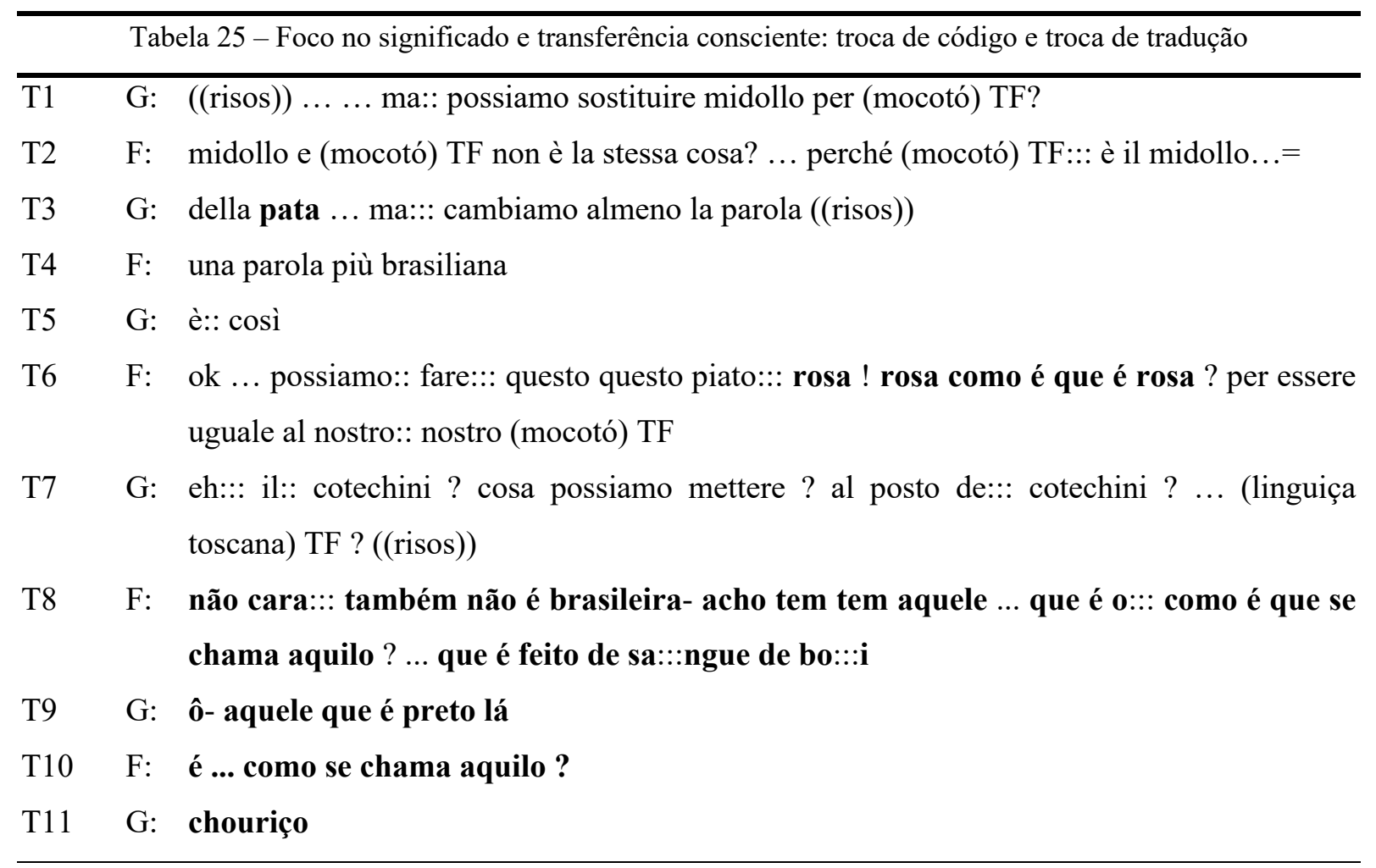

Continuam a discussão na LM a respeito dos ingredientes, mocotó e chouriço, de que eles não gostam, mas que podem deixar o prato com uma "cara mais brasiliana". Depois da decisão, retomam a receita, incluem novo ingrediente e escolhem o nome do prato (Tabela 26). 
Tabela 26 - Foco no significado e transferência consciente: troca de código e transferência fonética

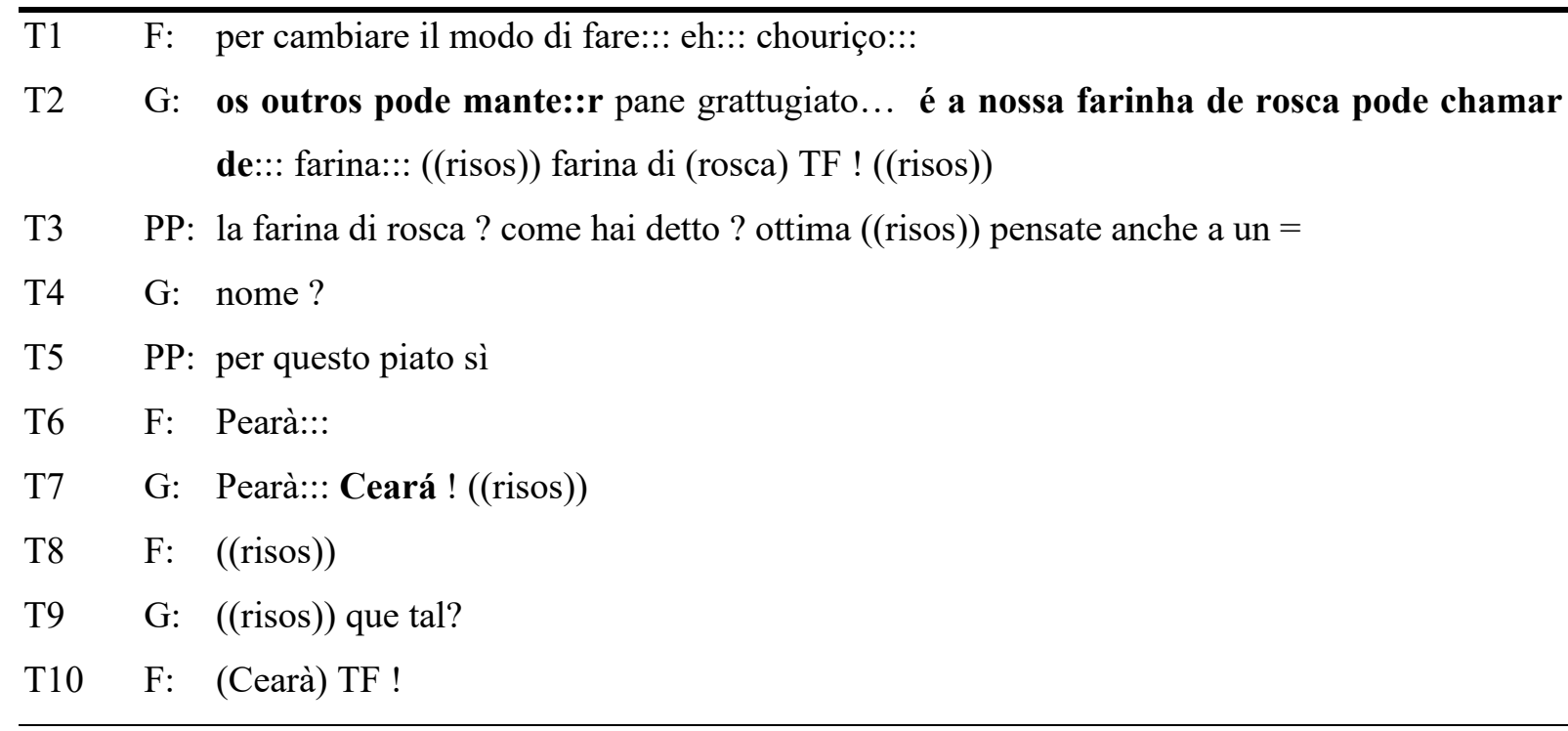

Como estratégias de comunicação, os aprendizes valeram-se da mudança de código para refletir sobre a atividade (T2); transferência fonética com pronúncia da LA em farina di rosca (T2) e na escolha do nome do prato Cearà, pronunciado como em italiano (T10).

\subsection{Análise da interação entre os aprendizes durante a tarefa Chi ha lingua va a Roma}

Da observação da transcrição da interação verbal entre os alunos durante a realização desta tarefa (Apêndice 8), dirigir-se a um local desconhecido, percebeu-se que esta foi a tarefa em que os alunos mais estiveram atentos ao foco na forma com conversas a respeito da conjugação verbal do Modo Imperativo. As maiores dificuldades foram em relação à pronúncia e à formas irregulares de verbos menos frequentes como uscire (sair). Notou-se também que grande parte das discussões focadas na forma são feitas na LM. E que os alunos refletem a respeito do uso que a professora da classe, italiana, faz do imperativo: comentam que a PC prefere usar a forma vai, do presente do indicativo em lugar da forma $v a$ ', registrada no dicionário que eles consultaram.

Interessante notar como os aprendizes dirigiram sua atenção para o foco na forma durante boa parte da interação, mesmo a tarefa não tendo sido elaborada com esse fim. Poderia ter sido empregado o Presente do Indicativo, como eles notaram que a PC, falante nativa de italiano, faz - tempo verbal que eles conhecem e dominam bem. Mas os aprendizes transformaram uma tarefa elaborada para atender o objetivo de se comunicar na LA em uma 
tarefa de ampliação de consciência, pela necessidade que sentiram de aprender a conjugação do Modo Imperativo.

A seguir apresentamos uma breve discussão dos resultados da análise das tarefas pedagógicas e da interação entre aprendizes durante a realização das tarefas em níveis iniciantes.

\subsection{Da interação entre os aprendizes durante a realização de tarefas}

Krashen (1981) afirma que a simples exposição dos aprendizes à LA é condição suficiente para a aquisição quando o insumo compreensível é oferecido em situações de baixo filtro afetivo (Hipótese do Input). Swain (1985), por outro lado, observa que esse insumo é necessário, mas não é suficiente, sendo igualmente necessária a produção (Hipótese do Output). Long (2015), por sua vez, defende que durante a negociação de significado, a atenção do aprendiz vai sendo direcionada à forma momentaneamente, recebendo ao mesmo tempo feedback e insumo adicional. E que esse foco na forma, melhora o processamento de insumo implícito, favorecendo a aquisição (Hipótese da Interação).

$\mathrm{Na}$ análise da interação verbal entre os aprendizes, foram observados vários exemplos de negociação de significado: alguns através do uso da LM, no emprego de estratégias de comunicação com troca de código, e outros através da própria LA. Nessa negociação, os alunos desenvolvem sua habilidade de expressão oral e aprendem, seja participando da negociação, seja ouvindo uma negociação entre os colegas na conversa de que participam (DONATO, 1994). São agentes criativos da própria aprendizagem, cabendo ao professor o papel de oferecer oportunidades para que essas negociações ocorram na comunicação real e oferecer também o suporte de que os aprendizes necessitem para avançar em direção ao próximo degrau.

Nesse sentido, a organização das tarefas pedagógicas em fases (WILLIS, 1996) mostrou-se favorável à preparação dos alunos para essa movimentação. No pre-task os alunos receberam insumo e coletaram informação. Durante a tarefa, eles negociaram significado e realizaram uma tarefa pedagógica inspirada em tarefas reais que eles têm interesse em realizar na LA (LONG, 2015). E no post-task puderam recapitular o que havia sido discutido e negociado, em uma nova oportunidade de apresentar as próprias ideias à classe de maneira mais assertiva e confiante. 
O monitoramento pessoal e colaborativo ocorreu em todas as fases, mostrando que o foco na forma, momentâneo, é natural da interação. Os colegas ofereceram suporte e feedback, tanto negativo quanto positivo, uns aos outros, mas observou-se, também, que muitas vezes o uso de formas inadequadas não é reparado, revelando que os aprendizes por vezes mantêm seu foco na mensagem que está sendo transmitida, chegando a conversar por longos períodos na LM, até mesmo sobre assuntos não pertinentes à aula, quando a atenção está priorizando a comunicação.

Assim, o foco na forma, realizado pelo professor também tem seu lugar. Ele provê o suporte para o aluno galgar alguns degraus na precisão com que ele pode se expressar, alcançando seus objetivos iniciais de "falar e comunicar-se da forma mais clara possível". Observou-se que foco na forma oferecido pela professora-pesquisadora, através de feedbacks negativos principalmente, ocorreu durante a realização das tarefas, quando ouviu algo na interação de que participava, ou quando foi acionada pelos alunos. E vimos o quanto esse formato interacional de tratamento de questões linguísticas é mais interessante do que as aulas expositivas de gramática.

$\mathrm{Na}$ aula expositiva, quando realizada na LA, os alunos podem receber exposição ao input, condição necessária, mas não suficiente para a aquisição de línguas - talvez por isso tantos alunos de cursos tradicionais estudam por anos, mas não conseguem se expressar com fluidez e clareza, sentindo-se inseguros para se comunicar na LA. Mostram-se igualmente necessárias a produção na LA e a interação, para que o foco na forma se apresente dentro de uma necessidade do aprendiz, e, sendo condizente com seu estágio de desenvolvimento e currículo interno (CORDER, 1967), possa ser adquirido de maneira eficiente e adequada. 


\section{CONCLUSÃO}

Buscando responder à pergunta "Como favorecer o desenvolvimento da expressão oral nos níveis iniciantes de italiano?", realizou-se nesta pesquisa um estudo a respeito do Ensino Comunicativo e do Ensino por Tarefas. A partir desse estudo, foi escolhido o Ensino de Línguas Baseado em Tarefas proposto por Long (2015) para guiar a elaboração das tarefas, através de seus Princípios Metodológicos.

Dentre as dificuldades que se apresentaram, a primeira delas foi a análise das necessidades. Os aprendizes geralmente expressam de maneira ampla seus objetivos e o que pretendem realizar na LA, o que dificulta a identificação das tarefas-alvo (LONG, 2015), e nesta pesquisa não foi diferente. Um dos alunos respondeu que a coisa mais importante em um curso de língua é "falar, comunicar-se da maneira mais clara possível" - um objetivo comum a todos os aprendizes participantes da pesquisa e, assim, buscou-se transformá-lo em tarefas pedagógicas. Outros objetivos apontados no questionário foram: conhecer melhor a cultura, compreender bem a língua, chegar em um nível avançado e ir estudar na Itália. Dentre as suas motivações estão o gosto pela arte, literatura e produção audiovisual italianas, a beleza da língua, interesse na sociedade e cultura italianas, a origem italiana da família.

A partir dessas informações, foram selecionados os episódios 5, 7 e 9 da série ficcional de DRF como pano de fundo para o tema das tarefas pedagógicas: Cercando lavoro, L'abito non fa il monaco, Ospitalità, Mangia che ti fa bene!, Chi ha lingua va a Roma.

Os vídeos de DFP foram desenvolvidos especificamente para o público brasileiro, característica que atende ao Princípio Metodológico de individualizar a instrução, trazendo mais motivação aos alunos.

Foram, então, elaboradas tarefas pedagógicas especificamente para esse público, estudantes brasileiros de uma faculdade de letras, a partir dos episódios escolhidos.

Pela da análise das tarefas propostas e da interação que elas promoveram entre os aprendizes, pôde-se verificar certas características que favorecem o desenvolvimento da expressão oral em níveis iniciantes, as quais são consideradas a seguir.

O DFP, por ser um material produzido para um público específico, trata de temas pertinentes para os aprendizes. Desde questões linguísticas à temas culturais, eles envolvemse com a trama e caminham junto com o protagonista na direção de seus objetivos. Os temas são relevantes e, além disso, assistir a um vídeo é sempre um momento de descontração na classe. 
O humor esteve presente na interação entre os alunos. Eles riram de suas dificuldades e também se divertiram com a realização das tarefas e na criação de palavras e estruturas novas. E se valeram da sua intuição de falantes para deduzir e decifrar significados e formas. E assim pode-se perceber que, na realização de tarefas pedagógicas, os aprendizes são protagonistas criativos do próprio processo de aprendizagem e aquisição.

A aprendizagem implícita e explicita estão presentes na realização das tarefas. Os alunos aprendem com o que ouvem e com o que fazem. O monitoramento de suas falas durante a interação traz sua atenção para o foco na forma. No monitoramento pessoal, o falante se observa e aperfeiçoa o próprio falar. As hesitações, pausas, prolongamentos de sons apontam para um processamento interno que está em ação, trazendo à consciência a melhor maneira de se expressar. Externamente, ocorrem autorreparos, fruto da atenção à forma da mensagem que se quer transmitir. No monitoramento cooperativo, o interlocutor é o espelho que reflete o que antes não havia sido percebido. É feito através de feedbacks positivos, confirmando a compreensão da mensagem transmitida, e negativos, mostrando que algo deve ser revisto para se comunicar com maior assertividade e precisão. Nesse suporte mútuo, os aprendizes seguem avançando, desenvolvendo suas interlínguas e se desenvolvendo.

Para que tudo isso possa fluir de maneira bem-sucedida, é importante que as tarefas sejam preparadas pelo professor com o devido cuidado: deve-se ter em mente o perfil dos aprendizes, seus interesses, objetivos, motivações e necessidades e levar em consideração a maneira de cada um estudar, aprender e se relacionar. É bom que se sintam confortáveis, confiantes e que percebam estão avançando. É razoável que a elaboração de tarefas seja baseada em conhecimento científico, mas é essencial o olhar do próprio professor, que percebe, a cada momento, qual Procedimento Pedagógico pode ser aplicado para que a tarefa proposta alcance seus objetivos. Durante a aula é preciso um olhar cuidadoso do professor para perceber o momento de abrir espaço para os alunos conduzirem os próprios passos e o momento de se aproximar para oferecer o suporte que eles necessitem, sempre atento aos sinais que a expressão oral dos aprendizes revela.

A realização desta pesquisa aponta para a direção de algumas possibilidades de trabalhos futuros como: elaboração e divulgação on-line de tarefas pedagógicas desenvolvidas a partir de DFP; o ensino de português baseado em tarefas para imigrantes e refugiados e publicação em língua portuguesa a respeito dos princípios do Ensino de Línguas Baseado em Tarefas, como suporte a professores da rede pública de ensino. 


\section{BIBLIOGRAFIA}

ALMEIDA FILHO, J. C. P. Dimensões comunicativas no ensino de línguas. Campinas: Pontes, 1998. $2^{\mathrm{a}}$ ed.

ALMEIDA FILHO, J. C. P.; BARBIRATO, R. C. Ambientes Comunicativos para Aprender Língua Estrangeira. In: Trabalhos de Linguística Aplicada. Campinas: Editora da Unicamp, (vol. 36): 23-42, Jul. /Dez. 2000. Disponível em: http://pgla.unb.br/wpcontent/uploads/2014/07/Artigo-Ambientes-Rita-e-Almeida-Filho.pdf. Acesso em 27 set. 17

BACCIN, P.; MAGGIO, G.; ORTALE, F. Dire, Fare, Partire! Um material didático on-line específico para brasileiros. In: ORTALE, F.; FERRONI. R. (org.) Luz, câmera, ação! O professor-autor da sala de línguas estrangeiras. São Paulo: Ed. Humanitas, 2017. p.101122.

CANALE; SWAIN. Theoretical Bases of Communicative Approaches to Second Language Teaching and Testing, Applied Linguistics, 1, p.1-47, 1980.

CELCE-MURCIA, Marianne. Rethinking the role of communicative competence in language teaching. In: Intercultural language use and language learning. Springer, Dordrecht, 2007. p. 41-57.

CONSELHO DA EUROPA. Quadro Europeu Comum de Referência para as Línguas: aprendizagem, ensino, avaliação. Tradução de Maria Joana Pimentel do Rosário e Nuno Verdial Soares. Porto: Edições Asa, 2001.

CORDER, S. P. The significance of learner's errors. IRAL-International Review of Applied Linguistics in Language Teaching, v. 5, n. 1-4, p. 161-170, 1967.

Disponível em: https://files.eric.ed.gov/fulltext/ED019903.pdf. Acesso em: 6 jan. 20.

DONATO, R. Collective scaffolding in second language learning. In: LANTOLF, J; APPEL, G. (orgs.). Theoretical framework: an introduction to Vygotskian perspectives on second language research, Norwood, NJ: Ablex, 1994, p. 117-134.

Disponível em: http://lchc.ucsd.edu/mca/Mail/xmcamail.2014-11.dir/pdf0VoMCAt tX.pdf. Acesso em: 6 jan. 20. 
ELLIS, N. C. Implicit and Explicit Knowledge about Language. In: Hornberger N.H. (eds) Encyclopedia of Language and Education. Boston, MA: Springer, 2008a. Disponível em: http://www-

personal.umich.edu/ ncellis/NickEllis/Publications_files/Implicit $\% 20$ and $\% 20$ explicit $\% 20 \mathrm{kno}$ wledge\%20about\%20language.pdf. Acesso em: 6 jan. 20.

ELLIS, R. Task-based Language Learning and Teaching. Oxford: Oxford University Press, 2003.

ELLIS, R. et al. Task-Based Language Teaching: Theory and Practice. Cambridge: Cambridge University Press, 2020.

FERRONI, R. As estratégias de comunicação durante a realização de tarefas feitas em colaboração por aprendizes de línguas próximas: rumo ao plurilinguismo. 2012. $288 \mathrm{f}$. Tese (Doutorado) - Faculdade de Filosofia, Letras e Ciências Humanas, Universidade de São Paulo, São Paulo, 2012.

HATCH, Evelyn Marcussen. Second language acquisition: A book of readings. Newbury House Pub, 1978.

HOUAISS, A. Grande Dicionário Houaiss. Rio de Janeiro: Instituto Antônio Houaiss, [201-]. Edição on-line. Disponível em: https://houaiss.uol.com.br. Acesso em 20 jan. 20.

HYMES, Dell. On communicative competence. In: J.B. PRIDE, J. B.; HOLMES, J. (eds.) Sociolinguistics: Selected Readings. Harmondsworth: Penguin, p. 269-293, 1972.

JANACSEK, Karolina; FISER, József; NEMETH, Dezso. The best time to acquire new skills: Age-related differences in implicit sequence learning across the human lifespan. Developmental science, v. 15, n. 4, p. 496-505, 2012.

KRASHEN, S. D. Second language acquisition and second language learning. Oxford: Pergamon Press, 1981. 1st ed.

KRASHEN, S. D. Second language acquisition and second language learning. Los Angeles: University of Southern California, 2002. 1st internet ed. Disponível em: http://196.189.45.87/bitstream/123456789/58723/1/26pdf.pdf. Acesso em 9 jan. 20. 
KRASHEN, S. D. The input hypothesis: Issues and implications. Londres e Nova Iorque: Addison-Wesley Longman Limited, 1985.

KRASHEN, S. D. The input hypothesis: An update. In: ALATIS, J. E. (Ed.) Linguistics and language pedagogy: The state of the art. Washington D.C.: Georgetown University Press, 1991. p.409-431. (Georgetown University Round Table on Languages and Linguistics). Disponível em: https://repository.library.georgetown.edu/handle/10822/555484. Acesso em 9 jan. 20.

KRASHEN, S.D. Principles and Practice in Second Language Acquisition. 1st internet ed. Los Angeles: University of Southern California, Jul. 2009. PDF. Disponível em: http://www.sdkrashen.com/content/books/principles_and_practice.pdf. Acesso em: 9 jan. 20

KRASHEN, S.D.; TERRELL, T. The natural approach: Language acquisition in the classroom. Oxford: Pergamon, 1983.

LARSEN-FREEMAN, D. Techniques and principles in language teaching. Oxford University, 2000.

LYSTER, Roy; RANTA, Leila. Corrective feedback and learner uptake: Negotiation of form in communicative classrooms. Studies in second language acquisition, v. 19, n. 1, p. 37-66, 1997.

LONG, M. H. Input, interaction, and second-language acquisition. Annals of the New York academy of sciences, v. 379, n. 1, p. 259-278, 1981. Disponível em: https://doi.org/10.1111/j.1749-6632.1981.tb42014.x. Acesso em 20 jan. 20.

LONG, M. H. (1983b). Native speaker/non-native speaker conversation and the negotiation of comprehensible input. In: Applied Linguistics 4, 2, p.126-141. Reprinted in Candlin, C.N., \& Macnamara, T. (eds.) (2001). A reader in applied linguistics. London: Routledge. Disponível em: https://doi.org/10.1093/applin/4.2.126. Acesso em 20 jan. 20.

. Problems in SLA. L. Erlbaum Associates, 2007.

. Second language acquisition and task-based language teaching. John Wiley \& Sons, 2015. 
MAYBERRY, Rachel I.; LOCK, Elizabeth. Age constraints on first versus second language acquisition: Evidence for linguistic plasticity and epigenesis. Brain and language, v. 87, n. 3, p. 369-384, 2003.

NUNAN, David. Designing tasks for the communicative classroom. Cambridge: Cambridge University Press, 1989.

ORTALE, Fernanda Landucci. A formação de uma professora de italiano como língua de herança: o Pós-Método como caminho para uma prática docente de autoria. 2016. Tese de Livre-Docência. Universidade de São Paulo.

PAULSTON, Christina Bratt. The sequencing of structural pattern drills. TESOL quarterly, p. 197-208, 1971.

PIENEMANN, Manfred. Is language teachable? Psycholinguistic experiments and hypotheses. Applied linguistics, v. 10, n. 1, p. 52-79, 1989.

PIENEMANN, M.; KESSLER, Jörg-U. Processability theory. In: The Routledge handbook of second language acquisition. Routledge, 2013. p. 246-264.

RICHARDS, J. C. Communicative language teaching today. New York: Cambridge University Press, 2006. Disponível em: https://www.professorjackrichards.com/wpcontent/uploads/Richards-Communicative-Language.pdf. Acesso em 1 dez. 19.

RICHARDS, Jack C; SCHMIDT, Richard W. Longman dictionary of language teaching and applied linguistics. Routledge, 2013.

RICHARDS, J. C; RODGERS, Theodore S. Approaches and Methods in Language Teaching. New York: Cambridge University Press, 2001. 2ed.

SCHMIDT, Richard W. The role of consciousness in second language learning1. Applied linguistics, v. 11, n. 2, p. 129-158, 1990.

SELINKER, Larry. Interlanguage. In IRAL-International Review of Applied Linguistics in Language Teaching, v. 10, n. 1-4, p. 209-232, 1972. Disponível em: https://doi.org/10.1515/iral.1972.10.1-4.209. Acessado em 20 jan. 20. 
SWAIN, M. Communicative competence: Some roles of comprehensible input and comprehensible output in its development. In: GASS, S.; MADDEN, C. (Ed.). Input in second language acquisition. Rowley, MA: Newbury House, 1985. cap. 14, p. 235-253.

UNIVERSIDADE DE SÃO PAULO. Agência USP de gestão da informação acadêmica. Diretrizes para apresentação de dissertações e teses da USP: parte I (ABNT) / Agência USP de Gestão da Informação Acadêmica; Vânia Martins Bueno de Oliveira Funaro (coord.). 4.ed. São Paulo: AGUIA, 2020. 76p. (Cadernos de estudos; 9). Disponível em: https://doi.org/10.11606/9788573140651. Acesso em: 05 jul. 20.

UNIVERSIDADE DE SÃO PAULO. Dire, fare, partire! Italiano para brasileiros. [201-] Disponível em: https://cursosextensao.usp.br/course/view.php?id=131. Acesso em: 25 jan. 20.

VAN LIER, L. The classroom and the language learner. London: Longman, 1988.

VIEIRA, D.A. A didatização de materiais autênticos para o ensino do italiano língua estrangeira. 2012. 278 f. Dissertação (Mestrado) - Faculdade de Filosofia, Letras e Ciências Humanas da Universidade de São Paulo, São Paulo, 2012.

WIDDOWSON, Henry George. Teaching language as communication. New York: Oxford University Press, 1978.

WIDDOWSON, Henry George. Context, community, and authentic language. TESOL quarterly, v. 32, n. 4, p. 705-716, 1998.

WIDDOWSON, H.G. O ensino de línguas para a comunicação. Trad. José Carlos Paes de Almeida Filho. Campinas, SP: Pontes, 1991.

WIKIHOW. Come vestirsi per fare buona impressione a un colloquio di lavoro. [S. I.], [20--]. Disponível em: https://www.wikihow.it/Vestirsi-per-Fare-Buona-Impressione-a-unColloquio-di-Lavoro. Acesso em 20 jan. 20.

WILLIS, J. A framework for task-based learning. London: Collins, 1996. 


\begin{abstract}
ANEXO 1
Definições de tarefa ${ }^{74}$

1 BREEN (1989): Uma tarefa é "um plano estruturado para a provisão de oportunidades para o refinamento de conhecimento e capacidades envolvidas em uma nova língua e seu uso durante a comunicação". Breen afirma especificamente que uma 'tarefa' pode ser "um breve exercício prático" ou "um plano de trabalho mais complexo que requer comunicação espontânea de significado."
\end{abstract}

2 LONG (1985): Uma tarefa é "uma parte de um trabalho realizado por si mesmo ou por outros, livremente ou por alguma recompensa. Portanto, exemplos de tarefas incluem pintar uma cerca, vestir uma criança, completar um formulário, comprar um par de sapatos, fazer uma reserva de um bilhete aéreo, pegar um livro emprestado em uma biblioteca, fazer um exame de direção, digitar uma carta, pesar um paciente, sortear cartas, fazer uma reserva em um hotel, preencher um cheque, encontrar um endereço e auxiliar uma pessoa a atravessar a rua. Em outras palavras, por 'tarefa' se entendem as várias coisas que pessoas fazem no dia a dia, no trabalho, na diversão e entre ambos. 'Tarefas' são as coisas que as pessoas vão lhe dizer que fazem se você lhes perguntar, não sendo elas linguistas aplicados.”

3 RICHARDS, PLATT e WEBER (1985): uma tarefa é "uma atividade ou ação que é completada como o resultado do processamento ou compreensão da língua, ou seja, como uma resposta. Por exemplo, desenhar um mapa enquanto se escuta uma gravação, e ouvir uma instrução e executar um comando, podem ser referidas como tarefas. Tarefas podem envolver ou não a produção da língua. Uma tarefa geralmente requer que o professor especifique o que será considerado como realização bem-sucedida da tarefa. Diz-se que o uso de uma variedade de diferentes tipos de tarefas no ensino de línguas o torna mais comunicativo ... já que oferece um propósito para a atividade de sala de aula que vai para além da prática da língua por si só.”

4 CROOKES (1986): Uma tarefa é "uma parte de um trabalho ou de uma atividade, geralmente com um objetivo específico, realizado como parte de um curso educacional, no trabalho, ou utilizado para coletar dados para pesquisa."

$5 \quad$ PRABHU (1987): Uma tarefa é "uma atividade que requer dos aprendizes que eles cheguem a um resultado a partir de informações dadas através de algum processo de pensamento e que permitem os professores controlarem e regularem o processo."

$6 \quad$ NUNAN (1989): Uma tarefa comunicativa é "uma parte do trabalho da sala de aula que envolve os alunos em compreensão, manipulação, produção ou interação na língua-alvo enquanto sua atenção está principalmente voltada ao significado, mais do que à forma. A tarefa deveria ter também um sentido de completude, sendo capaz de se estabelecer como ato comunicativo em si mesmo."

7 SHEHAN (1996a): Uma tarefa é "uma atividade em que: o significado é primordial; há algum tipo de relação com o mundo real; seu completamento tem alguma prioridade; e a avaliação do desempenho da tarefa se dá em termos de seu resultado.

8 LEE (2000): Uma tarefa é “(1) uma atividade de sala de aula ou exercício que tem: (a) um objetivo alcançável apenas através da interação entre participantes, (b) um mecanismo para estruturar e sequenciar interação e (c) um foco em troca de significado; (2) um esforço de aprendizagem de língua que requer que os aprendizes compreendam, manipulem e/ou produzam a língua-alvo enquanto realizam algum conjunto de planos de trabalho."

9 BYGATE, SKEHAN e SWAIN (2001) "uma tarefa é uma atividade que requer que os aprendizes usem a língua, com ênfase no significado, para alcançar um objetivo."

\footnotetext{
${ }^{74}$ Esta lista é uma tradução nossa da Figura 1.1: Exemplos de definições de uma 'tarefa' (ELLIS, 2003, p. 4-5)
} 


\section{ANEXO 2}

\section{Outras definições de tarefa}

10 ELLIS (2003: 16): “Uma tarefa é um plano de trabalho que requer que os aprendizes processem a língua pragmaticamente para alcançar um resultado que possa ser avaliado em termos de se o conteúdo proposto foi transmitido de maneira apropriada ou correta. Para tal fim, a tarefa requer que eles deem principal atenção para o significado e que façam uso de seus próprios recursos linguísticos, ainda que do desenho da tarefa possa predispô-los a escolher certas formas particulares. Uma tarefa tem a intenção de resultar num uso da língua que tenha uma semelhança, direta ou indireta, com o mundo real. Como outras atividades de língua, uma tarefa pode envolver habilidades orais ou escritas, de produção ou de recepção, e também vários processos cognitivos." 75

\footnotetext{
${ }^{75}$ A task is a work plan that requires learners to process language pragmatically in order to achieve an outcome that can be evaluated in terms of whether the correct or appropriate propositional content has been conveyed. To this end, it requires them to give primary attention to meaning and to make use of their own linguistic resources, although the design of the task may predispose them to choose particular forms. A task is intended to result in language use that bears a resemblance, direct or indirect, to the way language is used in the real world. Like other language activities, a task can engage productive or receptive, and oral or written skills, and also various cognitive processes."
} 


\section{APÊNDICE 1 \\ TERMO DE CONSENTIMENTO LIVRE E ESCLARECIDO}

\section{TERMO DE CONSENTIMENTO LIVRE E ESCLARECIDO}

Eu,

portador da cédula de

identidade $\mathrm{n}^{\circ}$.

autorizo o registro de minha participação na pesquisa de campo desenvolvida por Graziella Schettino Valente - mestranda em Língua Italiana pelo Departamento de Línguas Modernas da Faculdade de Filosofia, Letras e Ciências Humanas da Universidade de São Paulo (DLM-FFLCH-USP) e orientanda da Professora Doutora Giliola Maggio -, a ser realizada durante as aulas de língua italiana II no na Faculdade no segundo semestre de 2017.

A pesquisa tem por objetivo coletar dados sobre ensino de italiano e os instrumentos utilizados serão gravações das aulas em vídeo e em áudio.

Estou ciente de que tenho liberdade de retirar o meu consentimento em qualquer fase da pesquisa sem penalização alguma. A qualquer momento, posso buscar mais esclarecimentos, até mesmo relativos à metodologia do trabalho.

Declaro saber que as informações obtidas só podem ser usadas para fins científicos, de acordo com a ética na pesquisa, e que essa participação não prevê nenhum tipo de pagamento.

Declaro saber também que, caso seja necessário projetar a gravação em vídeo em contexto científico e acadêmico, a imagem da face do participante da pesquisa será preservada por borrão digital.

A pesquisadora se compromete a apresentar os resultados da pesquisa aos participantes antes que a versão final do trabalho seja divulgada.

( 入 ) Autorizo a gravação e a reprodução em vídeo e áudio.

( ) Autorizo a gravação vídeo e áudio e a reprodução apenas da gravação em vídeo.

( ) Autorizo a gravação vídeo e áudio e a reprodução apenas da gravação em áudio.

São Paulo,

Sou grata pela sua colaboração com esta pesquisa!

Graziella Schettino Valente

graziellasv@usp.br 


\section{APÊNDICE 2}

\section{QUESTIONÁRIO}

Cari studenti, benvenuti al nostro corso di italiano!

Peço que respondam a este questionário para que eu possa conhecer melhor o perfil de vocês e auxiliá-los a alcançar seus objetivos.

Grazie mille! Graziella Schettino

Nome:

Telefone:

Idade:

E-mail:

Profissão:

O que é mais importante para você num curso de língua estrangeira?

O que você entende por competência comunicativa?

Você gosta de estudar lendo e escrevendo ou prefere ouvir e falar?

Quais línguas estrangeiras conhece? Sente-se confortável para falar essa língua?

Por que decidiu começar o curso de italiano? Quais objetivos pretende alcançar?

Já estudou italiano antes? Como? Por quanto tempo? Há quanto tempo?

Quanto tempo você dedica semanalmente ao estudo do italiano além da sala de aula?

Prefere materiais de estudo impressos ou online?

Gosta de redes sociais? Quais você usa?

Numa escala de 0 a 10, quanto você se sente motivado a aprender italiano? Qual a sua maior motivação?

Você já tem outra graduação, pós ou especialização?

Você se considera uma pessoa extrovertida ou mais reservada?

Gosta de fazer novos amigos ou prefere cultivar as antigas amizades?

Conhece os vídeos de Dire, Fare, Partire? 
APÊNDICE 3

RESPOSTAS DOS APRENDIZES AO QUESTIONÁRIO

\begin{tabular}{|c|c|c|c|c|c|c|}
\hline & $\mathbf{M}$ & $\mathbf{R}$ & G & $\mathbf{F}$ & $\mathbf{J}$ & V \\
\hline idade & 19 & 39 & 22 & 28 & 24 & 21 \\
\hline $\begin{array}{l}\text { Por quê? } \\
\text { Objetivos? }\end{array}$ & $\begin{array}{l}\text { Interesse } \\
\text { pela língua } \\
\text { e cultura }\end{array}$ & $\begin{array}{l}\text { Origem } \\
\text { italiana. } \\
\text { Falar. } \\
\text { Comunicar- } \\
\text { se } \\
\text { claramente. }\end{array}$ & $\begin{array}{l}\text { Sociedade, } \\
\text { cultura e } \\
\text { artes. Estudar } \\
\text { na Itália. }\end{array}$ & $\begin{array}{l}\text { Origem } \\
\text { italiana } \\
\text { Beleza da } \\
\text { língua } \\
\text { Nível } \\
\text { avançado }\end{array}$ & $\begin{array}{l}\text { Pela rica } \\
\text { cultura } \\
\text { literária e } \\
\text { audiovisual }\end{array}$ & $\begin{array}{l}\text { Ouvir e } \\
\text { falar }\end{array}$ \\
\hline $\begin{array}{l}\text { Como } \\
\text { prefere } \\
\text { estudar? }\end{array}$ & Lendo & $\begin{array}{l}\text { Lendo e } \\
\text { escrevendo }\end{array}$ & $\begin{array}{l}\text { Gosta de } \\
\text { todas }\end{array}$ & $\begin{array}{l}\text { Lendo e } \\
\text { escrevendo }\end{array}$ & $\begin{array}{l}\text { Ouvindo e } \\
\text { falando }\end{array}$ & $\begin{array}{l}\text { Ouvindo e } \\
\text { falando }\end{array}$ \\
\hline $\begin{array}{l}\text { Estudou } \\
\text { italiano } \\
\text { antes? }\end{array}$ & Não & Não & Não & Não & Não & Não \\
\hline $\begin{array}{l}\text { Prefere } \\
\text { materiais }\end{array}$ & Impressos & On-line & Impressos & Impressos & - & Impressos \\
\hline $\begin{array}{l}\text { Usa redes } \\
\text { sociais? }\end{array}$ & Sim & Sim & Sim & $\begin{array}{l}\text { Não gosta, } \\
\text { mas usa. }\end{array}$ & - & Sim \\
\hline $\begin{array}{l}\text { Motivação } \\
(0 \text { a } 10)\end{array}$ & 8 & $\begin{array}{l}7 \\
\text { interesse por } \\
\text { uma nova } \\
\text { língua }\end{array}$ & 10 & $\begin{array}{l}9 \\
\text { Ler os } \\
\text { clássicos na } \\
\text { língua } \\
\text { original }\end{array}$ & - & $\begin{array}{l}9 \\
\text { Conhecer } \\
\text { melhor a } \\
\text { cultura. }\end{array}$ \\
\hline $\begin{array}{l}\text { considera- } \\
\text { se } \\
\text { extrovertido } \\
\text { ou tímido? }\end{array}$ & Reservada & $\begin{array}{l}\text { Reservado } \\
\text { Prefere } \\
\text { amizades } \\
\text { antigas. }\end{array}$ & $\begin{array}{l}\text { Extrovertido } \\
\text { Prefere } \\
\text { amizades } \\
\text { antigas. }\end{array}$ & $\begin{array}{l}\text { Reservado } \\
\text { Gosta de } \\
\text { fazer novos } \\
\text { amigos. }\end{array}$ & - & $\begin{array}{l}\text { Um pouco } \\
\text { reservada } \\
\text { Gosta } \\
\text { muito de } \\
\text { fazer } \\
\text { novos } \\
\text { amigos }\end{array}$ \\
\hline $\begin{array}{l}\text { Conhece os } \\
\text { vídeos de } \\
\text { DFP? }\end{array}$ & Sim & $\begin{array}{l}\text { Sim, mas não } \\
\text { os assistiu. }\end{array}$ & Sim & $\begin{array}{l}\text { Sim, já fez } \\
\text { parte. }\end{array}$ & - & Sim \\
\hline
\end{tabular}




\section{APÊNDICE 4}

Transcrição 1 - Cercando Lavoro

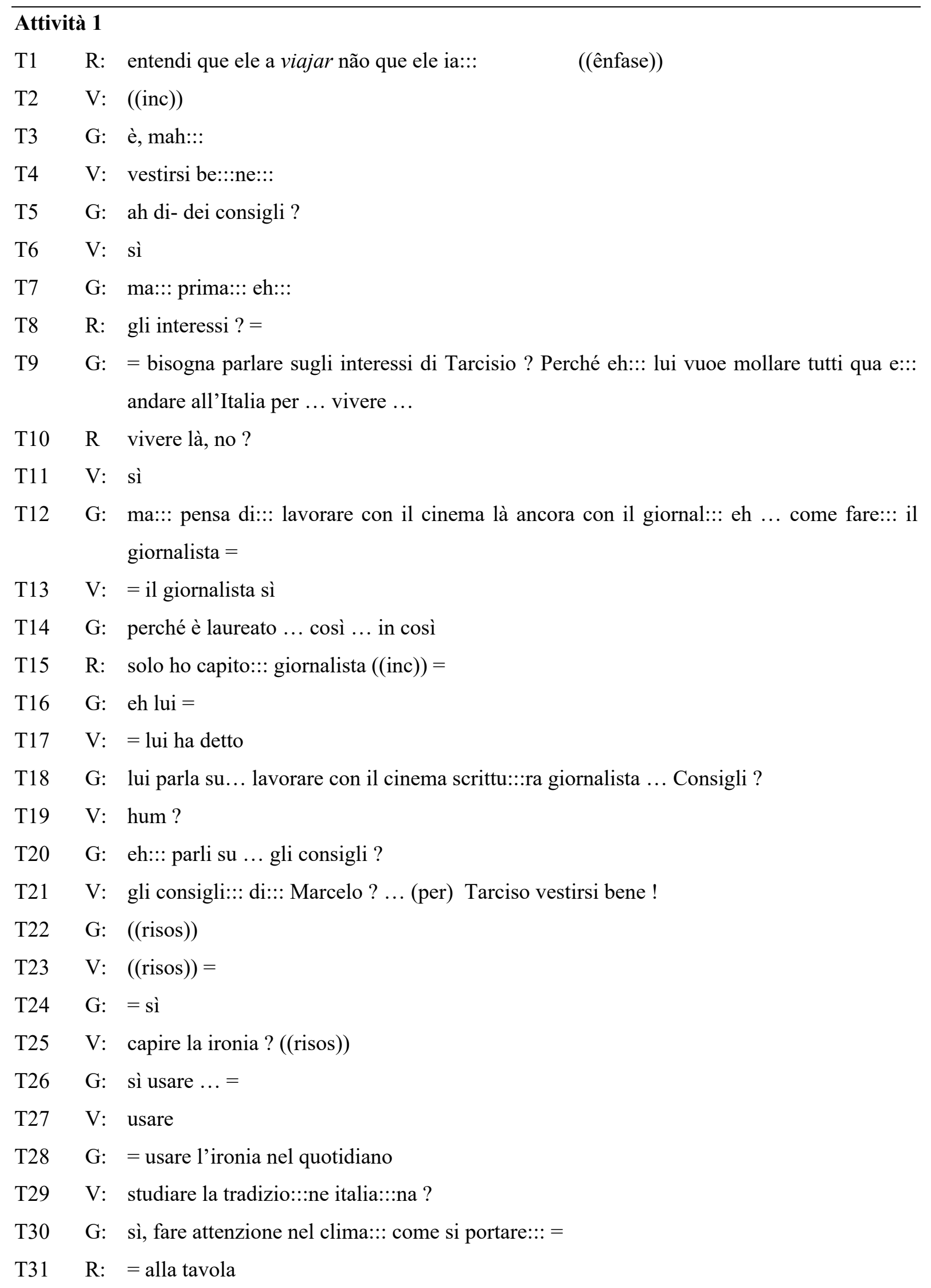




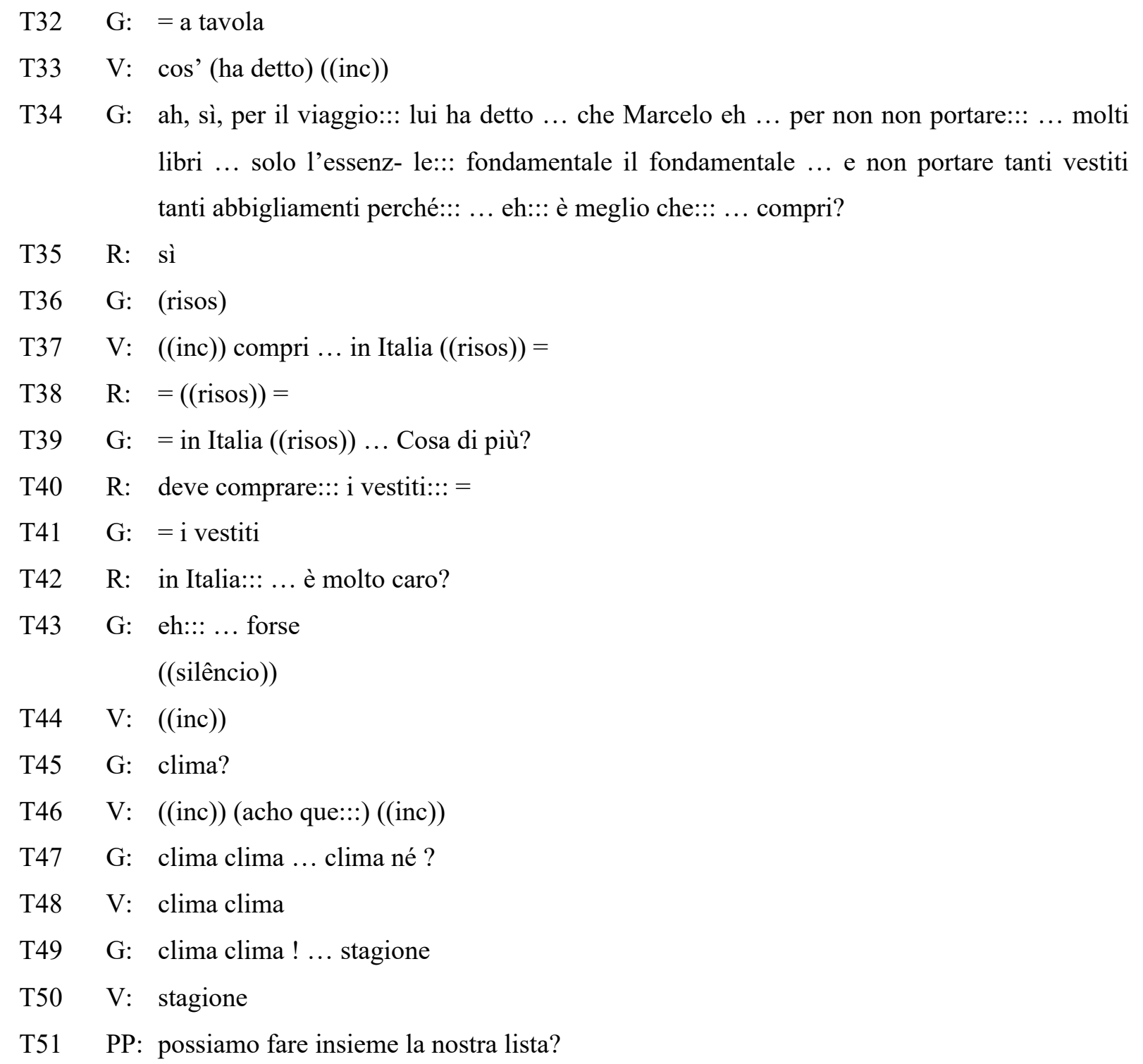

\section{Attività 2}

T1 G: Pensate che la::: conoscenza di una lingua è importante para per ... trovare lavoro? ... Di una lingua ? ... Quale ? ((risos)) $=$

$\mathrm{T} 2 \quad \mathrm{~V}:=(($ risos $))=$

T3 R: $=(($ risos $))$

T4 G: l'inglese forse? ((risos)) =

T5 $\mathrm{V}:=(($ risos $))$ l'inglese

T6 G: $=(($ risos $))$

T7 R: ((inc)) una lingua è importante::: =

$\mathrm{T} 8 \quad \mathrm{~V}:=$ sì

T9 R: oggi::: la lingua::: è un (differenciale) TF

T10 G: sì

T11 R: alcuni::: alcuni::: (vezes) 


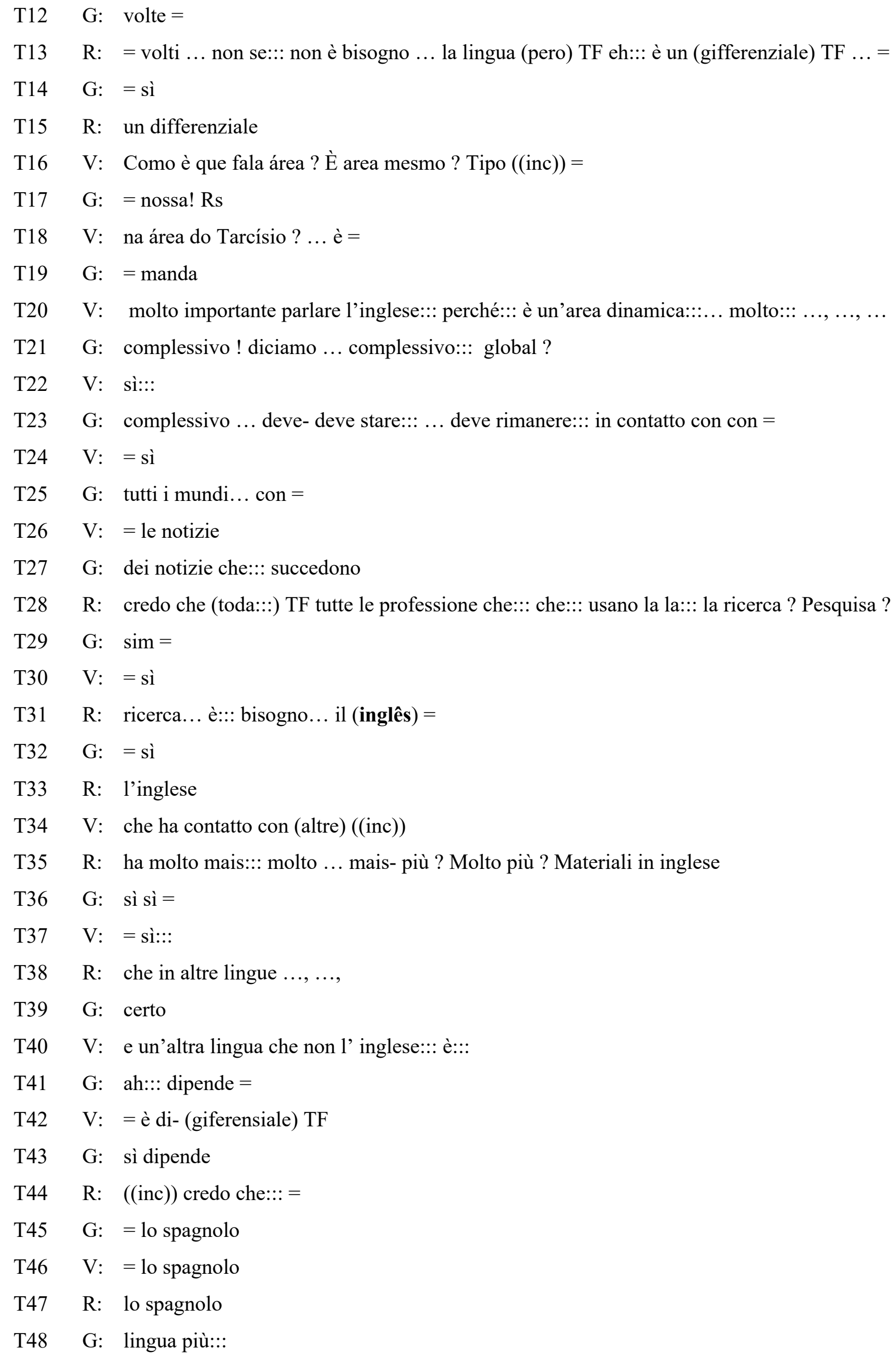


T49 R: all'europa:::

T50 V: tedesco:::

T51 R: tedesco::: $\ldots, \ldots, \ldots, \ldots, \ldots, \ldots, \ldots, \ldots, \ldots, \ldots$,

T52 G: Che tipo di lavoro pensate sarebbe più adatto per Tacisio Tarcisio in questo momento e perché? ..., Hum::: allora penso che sia una::: buona indicazione fare::: 1' insegnante di (portughese) TF quando::: =

T53 V: = hum::: ((risos))

T54 G: arrivare in Italia $(($ risos $)) \ldots$ non so se non so se::: hai qual- qualche interesse $(($ risos $))=$

T55 V: $=(($ risos $))$

T56 R: $=(($ risos $))$

T57 G: imparare portoghese là ... ma::: è un' opizione una::: =

T58 V: = sì:::

T59 G: un differenziale $(($ risos $)) \ldots ., \ldots, \ldots$, cosa di più ?

sì ! certo ! fare::: il giornalista ... Forse il giornalista sportivo perché::: penso che::: noi brasiliani: ... a noi ... né ! ... piacciono::. questi::: =

T60 R: $=$ sport

T61 G: temi::: sporti::: gli gli italiani anche ... Agli italiani anche $\ldots, \ldots, \ldots, \ldots, \ldots$, Spesso il calcio no!

T62 V: sì:::

T63 G: a loro piacciono ..., ..., un sacco:.: il calcio anche

T64 PP: (inaudível) sì?

T65 G: sì

T66 PP: ((fala com outro grupo e volta para este)) e voi ? Avete cercato qualcosa sull'internet?

T67 G: no ... possiamo fare::: adesso

T68 PP: sì Pensando ai punti che avete discusso::: le cose che avete pensato::: alle proposte::: cerchiamo qualcosa ... per Tarcisio c'è questo infojobs.it

T69 G: ..., ..., $(($ risos $))=$

$\mathrm{T} 70 \mathrm{~V}:=(($ risos $))$

T71 G: infojobs.it ... favoritando aqui $(($ risos $))=$

T72 V: = favoritando ((risos))

T73 G: ((risos)) já deixa um curriculão ali no it do infojobs $(($ risos $)) \ldots, \ldots, \ldots, \ldots, \ldots$,

T74 R: to tentando entrar na rede aqui

T75 G: ah, é uma tristeza ... ((risos)) infojobs it

T76 R: ((inc))

T77 G: sì, certo

T78 V: (prima) ((inc))

T79 PP: allora, possiamo fare una discussione insieme? 


\section{APÊNDICE 5}

Transcrição 2 - Cercando Lavoro: L'abito non fa il monaco

T1 G: ascolti secondo te come- como si vestono gli italiani ?

T2 F: l'italiane sono::: muito::: eleganti sempre::: vestono::: ... indossamento::: adequado ? ((abaixando o tom de voz)) per lavoro per la::: eh::: andare al parco::: e secondo te ?

T3 G: secondo ho capito::: loro::: hanno::: abbigliamento (specifichi) ES per ogni situazioni ... e::: cosa::: ... è si ecco penso che loro hanno questi::: come si dice:: ? ... ah::: questi criteri per: ((riso)) abbigliarsi

T4 F: $\quad$ sì $=$

T5 G: = abbigliar ... vi ((ênfase) $)$ não abbigliar::s- si $(($ ênfase $))=$

T6 F: = abbiliarsi

T7 F: eh eh eh eh:: Marcelo:: ha detto che::: è possibile:: ... . . comprar ? ((inc))

T8 G: $(($ risos $))=$

T9 F: = ah::: ((inc)) abbigliamento::: saldi ?

T10 G: sì

T11 F: Marcelo- $=$

T12 G: = sì lui ha detto che::: Tarcisio::: non::: non ... do- ... deve ? ... si preoccupare con::: cosa::: deve portare dei vestiti degli abbigliamenti perché::: ci sono::: ... anh::: ci sono saldi anche nell'Italia ((risos))

T13 F: ((risos)) sì

T14 G: alla moda ((risos)) ... brasiliana proprio

T15 F: sì Tarciso ha detto che::: bisogna di::: vestiti::: nuov- nuovo =

T16 G: = nuovi sì::. . .. bisogna di vestiti nuovi ... ... e che si veste di un modo molto sportivo:.:

T17 F: = sì pantaloni sportivi

T18 G: sì pantaloni::: ((risos)) ......

T19 F: certo ...

T20 G: allora ha anche ditto $(\mathrm{TF})$ che::: è un giornalista- un povero giornalista $(($ risos $))=$

$\mathrm{T} 21 \quad \mathrm{~F}:=$ sì

T22 G: quindi::: non- non è:::: non ha tanto soldi ........

T23 F: è questo né ?

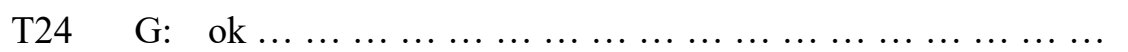

T25 F: è::: ((terminada a atividade, lê um tópico na folha de atividades, que transforma em pergunta e começa uma nova conversa)) Vestiti in modo appropriato alla cultura del lavoro ? ... ... Per un giornalista::: non bisogna di vestirsi::: =

T26 G: = ah dipende ! 
T27 F: dipende::: $=$

T28 G: se lavori in un New York Times forse:: deve:: vestirsi bene o:: non lo so ... avere una buona apparenza?

T29 F: se è un::: âncora ?

T30 G: sì sì (si) TF fa:::

T31 F: (si) TF fa reportaggio::

T32 G: (si) TF si fa il giornalista della tivu:::

T33 F: (si) TF lavora in un::: escritório ? ((inc))

T34 G: ufficcio!

T35 F: ufficcio::: (si) TF lavora in un ufficio forse non bisogna di::: ? (tá certo) =

T36 G: = eh ma oggi giorno ci sono $\ldots$ anh.:: quegli ufficci::: a::: start-ups eh... =

$\mathrm{T} 37 \quad \mathrm{~F}: \quad=\operatorname{sim}$

T38 G: dove non::: non bisogna::: andare::: ... tanto elegante o::: c'è una certa ... non lo so ((risos))

T39 F: (si) TF è un giornalista::: che (iscreve) TF per un blog:::

T40 G: sì o anche fa una cosa::: autônoma ? .........

T41 PP (( Orientações PP para a próxima atividade))

T42 G: scambiatevi idea sulle vostre opinioni sui consigli sottoelencati che consigli dareste a

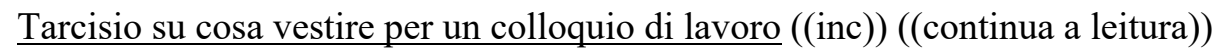

T43 F: valigetta?

T44 G: valigetta deve ser maleta né porque::: =

T45 F: = valigia

T46 G: = valigia valigetta $\ldots$ è forse $=$

T47 F: per le donne::: ((continuam a leitura em tom de voz mais baixo e depois em silêncio))

T48 PP ((PP oferece auxilio, aprendizes continuam a leitura em silêncio))

T49 F: último::: l'ultimo consiglio::: (vestiti) TF in modo (profecionale) TF anche per un colloquio al (telefono) TF eh::: ((suspiro)) prenderai il colloquio più seriamente

T50 G: $(($ risos $))=$

T51 F: $=(($ risos $))$

T52 G: ((risos)) bellissimo ((risos))

T53 F: por isso que eu tô desempregado ((rindo))

T54 G: ((risos)) ma che ô $::: ! !$ vedi come ... ((risos)) si (veste) TF oggi no ? eh ain vai in giro anche per la sua casa proprio in questo modo che:: ci ti sarai molti lavori ... segliere

T55 F: ((risos)) ah::: certo $! \ldots$... dobbiamo:: parlare (a) TR rispetto::: $=$

T56 G: sì ah::: scambiatevi (scambiaci) TF idea sulle vostre opinioni sui consigli sottoelencati che consigli dareste a Tarcisio su cosa vestire per il colloquio di lavoro ... ... per i 
colloqui non c'è non ci sono:: alternative perché:: mi sembra che:: ah:: dobbiamo sempre andare... formale in modo formale $\ldots$ anche se sia per un lavoro::: dove:: si usa::: a:::=

T57 F: uniforme ? ((sussurrando))

T58 G: ((inc)) ((risos)) como se fosse natural ((risos)) ok il colloquio è un evento specifico dove si presenta::. ...

T59 F: sì un consiglio::: che::: ... per colloquio si::. ... quer ? como que fala ? se quer ((tom de voz mais baixo)) se lui:::

T60 G: v-vole?

T61 F: v- vuoi ? Voglia ?

T62 G: vuole volere $=$

T63 F: volere ? eh::: vestirse come::: la persona che::: già:::

T64 G: lavora

T65 F: lavora là $=$

T66 G: = lavora là

T67 F: Con::: con::: la::: lavoro che::: ... tu::: quer- voglia

T68 G: vuoi che $\mathrm{v}-\ldots$ vuole o che vuoi $(($ risos $))=$

T69 F: eh!

T70 G: ((risos)) dipende della persona

T71 F: $\quad(($ risos $))=$

T72 G: $=(($ risos $))$

T73 F: (e:::) TF ... per stare come una persona che::: (ocupa) TF questo:: questo lavoro

T74 G: sì ... eh penso che per Tar- eh::: Tarcisio eh::: lui deve eh::: ... osserva::re eh::: come gli italiani si vestono la ah:: come ... eh:: che tipo di v- abbigliamento loro vestono ... nella giorna::ta ... perchè come ha detto Marcelo loro hanno speci- eh:: vestiti (specifichi) TF per ogni occasione $=$

T75 F: = sì

T76 G: quindi::: eh:: lui deve tentare di ... lui deve provare di ... di di ... ... di usc- di di ((risos))

T77 F: fugiu o verbo $(($ risos $))=$

T78 G: ((risos)) enfim ((risos))

T79 F: (conicere-) TF (conocere) TF la::: =

= sì cono::scere

T80 F: la (impre::sa::) TF (impresa) TF?

T81 G: Azienda!

T82 F: Azienda ! =

T83 G: = Azienda o:: l'ufficio

T84 F: che::

T85 G: A- azienda la pronuncia:: 
T86 F: $\quad(($ risos $))=$

T87 G: $=(($ risos $))$ è sempre::: dificile per me ((risos))

T88 F: è ... il consglio::: prima il consiglio è vestirsi- vestirti be::ne:: per::: =

$=$ ah $!$ aggiungere no $!$ ri- ri- riuscire $?$ nao $\ldots$ risc- $\ldots$ ho dimenticato $\ldots$ tutti $\ldots$ è que tem um verbo conseguir ma- $=$

T89 F: = ah não (não vou saber)

T90 G: ((risos)) ra- rius- riusci-

T91 F: nao sei ((sussurrando))

T92 G: quer ver ? ... eu juro que tem $(($ risos $)) \ldots . . . .$. é porque è irregular também tá ? ((checam a palavra conseguir no celular)

T93 F: ottenere ? per ottenere::: un- $=$

T94 G: = riuscire ! ...

T95 F: riucire?

T96 $\mathrm{G}=$ sì ... per riuscire::: il lavoro che vuoi- che vuole ... ma vedi... ahm:: penso che:: lui vorrebe:: riuscire un lavoro come::: il stesso- il stesso- lo stesso lavoro che fa qua ... come ... come giornalista fa facere:: facere:: il giornalista ... =

T97 F: = sì

T98 G: quindi:: eh:: mi ricordo che lui ... =

T99 PP: $=(($ para toda a classe $))$ facciamo insiemi ?

T100 G: faceva recensioni sui film non ha bisogno di::: andare- portare:: formale ((começa a discussão com toda a classe)) 


\section{APÊNDICE 6}

Transcrição 3 - Ospitalità

T1 F: ok. A chi (telefona) TF tarcigio ? eh:: mi sembra che::: lui ha parlato con li suo zi::o ... Angelo zio Angelo mi sembra eh:::che Fabio ... è padre di Tarcigio

T2 M: um-hum

T3 F: non lo so se::: è certo ! eh:: per quale squadra fa il (cifo) TF Tarcigio ? Non lo so mi sembra Juventus perché::: um::: momento ((abaixa o tom de voz)) eh:::=

T4 M: = non lo so

T5 F: lui::: ha detto che l'altra squadra nã::o eh:::: como que se diz ... tao boa quanto la Juve di Torino ...

T6 M: um-hum

T7 F: mi sembra che che lui fa il tifo per Juve ((suspiro)) eh::: quando comprerà i biglietti Tarcigio eh:: lui ha detto forse fra due mese::: non lo so quale parola

T8 M: Cerca due mese

T9 F: sì eh... quê mais ? la famiglia di Tarciso gli potrà ospitare ? no

T10 M: se não ele não taria pedindo

T11 F: non so ... che ah::: ci sono c'è muita::: (burocaci::a) TF e questo:: non potrà ospitare l'ospitare eh::: cosa è peara peara pearà non non ce non se come si parla $=$

T12 M: pearà

T13 F: è un pia::to:: veronese, è isso ? eh... piato veronese eh... sette quali sono gli ingredienti della pearà secondo Marcelo ? ahm... io non capisco:: tutte le parole che:: (ele) TR ha detto ... eh però::: lui ha detto che c’è:::: (purê) TF ... qualcosa con burro pane

T14 M: eh molte parole peppe pão::: =

T15 F: = non capito tutto

T16 M: non capisco

T17 F: eh::: quali sono gli ingredienti parará eh... lui ha detto anche:: che non si trova:: questo piatto:: $=$

T18 M: $=$ in (restaurante) TF

T19 F: in (restauranti) TF che si (face) ES in ca::sa con la fami::glia

T20 M: può essere:: comida:: della cucina ... povera ?

T21 F: sì sì ... q- q- qualcosa::: in questo (sentido) TF

T22 M: (face) ES una sintese

T23 F: sì

T24 M: non capisco eh... il tifo

T25 F: eh- fa il tifo português:: fa il tifo per il corintiã- torce pelo corintians 
T26 M: ah sim mas não capisco per- ... ((inc)) ele né? =

T27 F: = ah sì non so:::

T28 M: ((inc)) juventus né ?

T29 F: mi sembra che lui fa il tifo per in un momneto lui ha detto che l'altro:: l'altra squadra non è̀::: piu ::: qualquer coisa ((risos)) come juve di torino ... non so

T30 M: ha parlato (huventus) TF né?

T31 F: lui ha parlato la juve di torino no? ((dirigindo-se à professora-pesquisadora))

T32 PP: sì

T33 M: ah... non capisco

T34 PP: facciamo insieme allora? 


\section{APÊNDICE 7}

Transcrição 4 - Mangia che ti fa bene!

T1 G: quali ingrediente hai ascolto?

T2 F: non molto ah::: midollo pane

T3 G: pane gratuggiato:: a farinha pepe ((inc)) ... fa la salsa salsa o pearà né

T4 F: eu não ouvi salsa

T5 G: ((inc)) só depois ele adiciona ((inc)) sciogliere::: ((olhando no dicionário)) liberar soltar ... pode se:::r ((escrevendo)) sciogliere il mido::llo lentame:::nte ... dopo aggiungere il pa:::ne gratuggiato ... tostare molto be:::ne ... per non brucciare ... il pane

T6 F: brucciare è queimar ?

T7 G: bru- brugia- $=$

T8 F: brucciare né ?

T9 G: $\operatorname{com~C}$ ?

T10 F: è ! com C

T11 G: bru cia re $(($ escrevendo $))$... dice non bruciare il pane dopo::: eh cosa deve::: $=$

$\mathrm{T} 12 \mathrm{~F}:=$ mescolare

T13 G: = mescolare con la frustra?

T14 F: mescolare ma non so come deve mescolare $=$

T15 G: = solo midollo e pane grattugiato ? o c'era::: cosa di più ... ((inc)) per quattro o cinque minuti... a:::hn dopo lasciare bugliare la salsa per due hore due hore e mezza al fuoco:: lento?

T16 F: fuoco lento .......

T17 G: io ho ascoltato pepe ma::: per raggiungere dopo né?

T18 F: no:::n

T19 G: lui dice cose qche la peara si (inc)) dopo possiamo aggiungere pepe

T20 F: cos'è pepe?

T21 G: pimenta né ? ((risos)) pura dedução ... ele fala que o que dife::re a pearà è que vai pime::nta eu ouvi- ou que não vai também $(($ risos $))=$

T22 F: $=(($ risos $))$ io non ho ascoltato

T23 G: de tudo que a gente pegou é::: aggiungere il mido::lo

T24 F: midolo è o que ? osso ?

T25 G: não sei ...poi agiungere::: pane grattuggiatto $=$

T26 F: = pane

T27 G: ah ! tostare molto bene per quattro cinque minutti

T28 F: non brucciare il pane 
T29 G: tostare per cinque minuito ma:::

T30 F: mescolare tutto ((risos))

T31 G: ((risos)) ... lasciare buiare per altre due ore- ah no ! - mescolare con la frustra ?

T32 F: frustra ((inc)) aveva parlato di fare::: abbastanza liquido

T33 G: deve essere tra il denso e il liquido

T34 F: sì

T35 G: non deve lasciare molto ahn:: liquido ((inc)) dopo lasciare buiare per due ore due ore e mezza buiare è ferver né ?

T36 F: um-hum

T37 G: ((inc)) al fuoco baixo ? lento ? ((pergunta para alguém em outro grupo))

T38 J: ele falou baixo

T39 G: vou colocar fogo baixo mesmo pode se::r piano fuoco piano ... acho que é isso

((Falam em portugues de outro assunto da faculdade))

T40 PP: e come va la vostra riccetta?

T41 G: hum:: brucciatta ? ((risos))

T42 PP: avete bisogno di aiuto con qualcosa o l'avete finita?

T43 G: pensiamo che siamo::: eh:: al punto ((risos)

T44 PP: ah bene ! e come l'avete preparata questa pearà ?

T45 G: allora::: ((fala com o auxilio das anotações)) dobbiamo aggiungere il midolo eh::: sciogliere lentamente- il midollo dopo::: aggiungere il pane grattugia::to tostare molto bene per cinque minuto- cinque minuti $=$

T46 PP: = um-hum

T47 G: ma non bruciare il pane

T48 PP: sì

T49 G: eh::: mescolare tutto con la frustra

T50 PP: um-hum

T51 G: eh::: addenzare in modo che::: non sia molto liquido

T52 PP: sì

T53 G: e dopo:: lasciare buiare per due ore due ore e mezza a fuoco:: le::nto è lento lento mesmo ?

T54 PP: sì fuoco lento sì ... ah... il verbo qua::: ferver é bo lli:: re

T55 F: bollire?

T56 PP: sì sì

T57 G: (cuocire) TF per due ore

T58 PP: cuocere ((ênfase)) per due ore- si ... boll::ire con doppia elle

T59 G: ah! doppia elle?

T60 PP: sì ... allora come vi pare questa parte ? la crema la pearà ? ti sembra buona? 
T61 G: sì ...

T62 PP: la assaggeresti ?

T63 G: sì

T64 PP: ((para F)) e tu ? come ti pare ? c'è qualche ingrediente che non ti piace ?

T65 F: midollo:::

T66 PP: il midollo sì è un po' strano no ? non ti piace ?

T67 F: no .........

T68 PP: va bene vediamo con le altre colleghe e facciamo la seconda parte la parte con il cotechino

((Falam em português de outra disciplina ))

T69 PP: questa è l'attivittà numero quattro ok?

T70 G: ok ... hum::: cosa possiamo sostituire ? sos ti tuire

T71 F: sostituire midollo pe:::r mais ? ((risos))

T72 G: ((risos)) ma ! non c'è qualcuna- qualche ((correspondenza)) TF !

T73 F: ma::: l'apparenza:::

T74 G: ...... possiamo::: mettere::: ... mocotó ! ((risos))

T75 F: ((risos)) mocotó mocotó

T76 G: mocotó cara !

T77 F: mocotó sempre tem um carinha forte na embalagem

T78 M: ((chegou no grupo durante a atividade)) ((inc))

T79 G: ah:: eu comia quando era menino tá ligado ?

T80 F: quando io ero bambino mio padre eh::: me obrigava $=$

T81 G: $=(($ risos $))$ obbligava ?

T82 F: um-hum a mangiare per questo:: non mi piace $\ldots$ ancora però $=$

T83 G: = proprio perché loro dicevano che ti farebbe più forte

T84 M: ((inc))

T85 G: ((risos)) ... ... ma:: possiamo sostituire midollo per mocotò ?

T86 F: midollo e mocotó non è la stessa cosa? ... perché mocotó::: è il midollo...

T87 G: della (pata) TF ... ma::: cambiamo almeno la parola ((risos))

T88 F: una paraola più brasiliana

T89 G: è̀:: così

T90 F: ok ... possiamo:: fare::: questo questo piato::: rosa ! rosa como é que é rosa ? per essere uguale al nostro:: nostro mocotó

T100 G: eh::: il:: cotechini ? cosa possiamo mettere ? al posto de::: cotechini ? ... linguiça toscana ? ((risos))

T101 F: não cara::: também não é brasileira- acho tem tem aquele ... que é o::: como é que se chama aquilo ? ... que é feito de sa::::ngue de bo:::i 
T102 G: ô- aquele que é preto lá

T103 F: é ... como se chama aquilo ?

T104 G: chouriço

T105 F: é- chouriço ... mas aquilo lá acho que é italiano- italiano não espanhol tem um nome espanhol praquilo também que eu não vou lembrar agora mas acho que ((inc))

T106 G: mas pra ficar com a cara brasiliana: linguiça toscana ((risos)) brasileira com o nome da região italiana $(($ risos $))=$

$\mathrm{T} 107 \mathrm{~F}:=(($ risos $))$

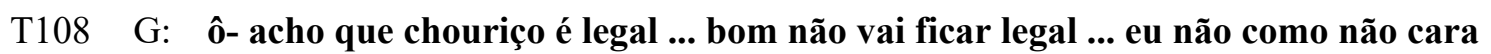

T109 F: meu pai adora essas coisas

T110 G: sério mano ?

T111 F: é o meu vizinho fazia e vendia pro meu pai

T112 G: tá maluco cara o bagulho é feito com o sangue do boi

T113 F: é sangue de porco- bom pelo menos o meu vizinho fazia com sangue de porco bom entao a gente tem que explicar em italiano como se faz né ? choriço::: eh::: como si (face) ES ?

T113 G: primeiro mocotò ((escrevendo))

T114 M: sostituire midollo per mocotò que è a mesma coisa mas ((inc))

T115 F: bom aí eu não sei se è de uma parte especifica ma:::s

T116 G: acho que era uma parte da pata

((continuam em portugues))

((PP vem e diz que agora será feita a apresentação para a classe))

T117 F: per cambiare il modo di fare::: eh::: chouriço:::

T118 G: os outros pode mante::r pane grattugiato... é a nossa farinha de rosca pode chamar de::: farina::: ((risos)) farina di rosca ! ((risos))

T119 PP: la farina di rosca ? come hai detto ? ottima ((risos)) pensate anche a un $=$

T120 G: nome?

T121 PP: per questo piato sì

T122 F: Pearà:::

T123 G: Pearà::: Ceará ! ((risos))

T124 F: ((risos))

T125 G: ((risos)) que tal?

T126 F: Cearà ! (TF)

T127 G: Pearà ou Piauí ?

T128 F: Pará

T129 G: ((inc)) ............

T130 F: então ... chouriço si fa::: con l'intestino di maia::le e con il sangue ... 
T131 G: ((inc))

T132 F: giacché il nostro piato si chiama Ceará (TF) ! possiamo fare solo con maiale (cearense) $\mathrm{TF}$

T133 G: beleza

T134 F: se non non è un vero Ceará

T135 G: é um fak-ará ((risos))

\section{POST-TASK}

((os grupos apresentam seus pratos))

T1 PP: e il vostro piato come si chiama?

T2 F: Cearà

T3 PP: Cearà ? bravi! ((risos)) e come fate la Cearà ?

T4 G: abbiamo pensato di ad- ad-adare?

T5 PP: adattare?

T6 G: addattare il piato italiano in una cosa veramente brasiliana

T7 PP: sì

T8 G: quindi::: sostituiriam- sostistu- riamo ?=

T9 PP: sostituiamo

T10 G: il midollo per mocotó

T11 ??: Oh:::

T12 G: il process- il processo è il stesso eh::: ma::: anche sostituriamo ... il cotechini per chouriço

T13 PP: chouriço !

T14 G: ci sarà un- un un gusto ? un gusto ?

T15 PP: sì

T16 G: più nordestino

T17 PP: bene ! e questa l'assaggieresti tu:: ?

T18 ??: No

T19 G: ((risos)) neanche noi ((risos))

T20 PP: neanche voi ? ((risos))

T21 F: ((risos)) no !

((continua conversa com a turma)) 


\section{APÊNDICE 8}

Transcrição 5 - Chi ha lingua va a Roma

T1 M: che è messo ? ((na folha de atividades)

T2 F: messo::: ho messo::: acho que é ....

T3 M: ah::: deixa ! ...

T4 PP: ((para toda a classe)) sì ? possiamo ascoltare ? possiamo vedere ? ... qualche parola nuova? tutto ok M ?

T5 M: mais ou menos

T6 PP: mais ou menos ? hai bisogno di aiuto con qualcosa?

T7 M: messo ?

T8 PP: sì::: messo::: =

T9 M: $=\cos$ '̀े ?

T10 PP: ho messo ? è il passato del verbo mettere

T11 M: ah::: brigada

T12 PP: sì ?

T13 M: sì

T14 R: cos'è aeroplanino ?

T15 PP: un aeroplano ... piccolo ... ricordate del video che Tarciso ha fatto ?

DURING TASK 1((segue a conversa com toda a classe, PP dá orientações))

((no trabalho em grupo, F e M checam suas respostas))

$\mathrm{T} 1 \mathrm{~F}$ : la prima::: tarciso sì ?

T2 M: sì

T3 F: questo::. ... bom penso che è elisa:: elisia o elisa ?

T4 M: elisa

T5 F: sì penso che è elisa perché::: è questo- vuol dire che::

T6 M: elisa

T7 F: elisa

T8 M: cittadinanza

T9 F: lei parlava::: la stessa:::

T10 M: la stessa palavra ? ele falou também ?

T11 F: no no perché::: c'è tre volte che elisia::: elisa::: penso che è lei che ha detto questo::: frase não sei como è que è frase

T12 M: frase ... frase

T13 F: ho messo- ho messo un aeroplanino che passa::: 
T14 M: sentenza

T15 F: ahn?

T16 M: sentenza

T17 F: sentenza

T18 M: ah tá aqui ó

\section{POST-TASK 1}

((PP corrige atividade de compreensão com toda a classe e dá orientações para a próxima fase da tarefa))

T1 F: ((inc)) ((lendo a folha de atividades))

T2 M: tarciso ha::: mostrato ... mostrato ? ... ...... tarciso ha parlato::: a rispetto sua::: sorella

T3 F: sì $\ldots \ldots \ldots$ loro::: parlavano::: di un tale signor $\mathrm{C}$ che::: mi sembra qualcuno che::: scriveva per la madre di tarcisio ? ... ((inc))

T4 M: ele escrevia pra alguém ((risos))

T5 F: hum::.: ......... o quê mais ? ... ..... non ricordo quello che hanno parlato

T6 $\quad$ M: non ricordo $\ldots \ldots \ldots \ldots \ldots \ldots \ldots$ tarciso scrive::: qualcuno- qualcosa- qualcuna cosa ?

T7 F: non so ... lui ha parlato qualcosa su::: sulla Italia:::

T8 M: passaporto

T9 F: hein ?

T10 M: passaporto

T11 F: è possibile perché::: non mi ricordo ... perché quando il video::: tava passando fiquei ((inc))

T12 M: ((risos))

T13 PP: ((para toda a classe)) facciamo insiemi la lista ?

\section{Aula seguinte: Attività 3}

T1 PP: puoi leggere J per favore ?

T2 J: tarcisio è al consolato guardate il video e rispondete come arrivare all'ufficcio dove $\underline{\text { ritirare il suo passaporto attenzione alle espressioni usate per indicare direzioni }}$

T3 G: nossa dificil ((durante o video G vai faz anotações)

T4 G: esce

T5 J: como que é? escere ? la porta ? que ele fala não sei o que per la porta ? como que é ? esce?

T6 G: acho que è esce di::: di uscire ((assistem trecho do video))

T7 J: esco la ?

T8 G: salga la scala a destra $=$ 
T9 J: ((inc)) le scade?

T10 G: la scala

((assistem trecho do video))

T11 G: fino al secondo piano ((escrevendo)) con doppia enne

T12 G: corriduoio::: entra nella seconda stanza a sinistra ((antecipando o video))

T13 J: entra

T14 ??: instanza o stanza ?

T15 G: $\quad$ stanza $=$

T16 PP: = stanza $\ldots$ sì ? possiamo fare la discussione insieme con il collega ?

((PP pede a alguns colegas para se aproximarem dos grupos que têm gravador))

T17 J: então prima ha detto: vado al fino in fondo al (corredoio) ES

T18 G: é- isso-

T19 J: dopo::: esco la per la porta ? cosa è esco la ?

T20 G: non capisco

T21 J: poi deve nãnãnã a destra fino $=$

T22 M: alla scala

T23 G: salire la scala al secondo piano

T24 F: $\operatorname{sim}$

T25 J: continui per corridoio::: e entra (na) TR seconda stanza a sinistra

T26 M: a sinistra

T27 J: cos'è stanza ?

T28 F: stanza é quarto né ?

T29 J: é o quê?

T30 F: quarto sala $=$

T31 G: = stanza é sala ... può essere aula

T32 J: eu vou ver o que é esse negócio de:::

T33 G: que é bem loco né =

T34 F: $=\operatorname{sim}$

T35 G: aula é sala e lezione é::: é aula né ? =

T36 F: = pra gente fica:::

T37 J: eu tô gravando ? ai que susto ... xô tentá ... será que:.: como se escreve esse tal de esco:: esco::

T38 G: é do verbo uscire $=$

T39 F: é do verbo uscire né ? sair né ?

T40 J: é?

T41 G: esco esci esce usciamo uscite escono

T42 J: meu deus parece pokemón 
T43 F: eh::: não sei como::

T44 J: dexa eu ver essa::: conjugação $=$

T45 G: = quando é feio assim a coisa::: traumatiza né ? ((risos))

T46 PP: queste sono le forme del presente:: e la forma che tu hai sentito qual'era?

T47 J: esco- esco la

T48 PP: com' è ?

T49 J: esco la per la porta

T50 PP: esca

T51 J: ah:::::

T52 G: esca

T53 J: esca

T54 G: é esca

T55 J: ah:::: entendi ... io esco tu eschi::

T56 G: esci

T57 J: ((escrevendo)) usci::te escono ... ((consultando no celular)) é aqui não tem o:::

T58 M: imperativo $=$

T59 G: = imperativo

T60 J: ah o imperativo tá aqui em baixo?

T61 G: eh::: o:: =

T62 J: = imperfeito

T63 G: imperfeito ... não tem mais ?

T64 J: ...... congiunti:::vo::: ... imperati::vo::: ((procurando)) imperativo aqui

T65 M: esca ! =

T66 G: = esca

T67 J: eschi esca

T68 G: ah ! o esca éhh.... é formale ?

T69 J: uscite escano .... è irregolare $(($ risos $)) \ldots$ ho sentito esco la $=$

T70 G: = questo verbo salire anche::. difficile ... salire

T71 PP: sì ? siete già d'accordo ?

T72 J: ã-hã

T73 PP: ((para o outro grupo)) raggazze possiamo fare insieme ?

POST-TASK 2

((começa o post-task))

T1 PP: dunque la prima indicazione qual è ?...... ce ne sono cinque

T2 G: va

T3 V: ((de outro grupo)) vado 
T4 PP: come?

T5 V: vado

T6 F: vada

T7 PP: vada sì

T8 J: vada?

T9 G: vada?

T10 F: deve ser o imperativo de novo- vada

T11 J: ãhh::

T12 PP: vada fini in fondo al corriduoio sì

T13 G: é porque o outro é vai

T14 J: éh::: ?

T15 G: vai vai vai é o que a gente mais ouve a PC ((a professora deles que è italiana)) falar

T16 F: in o il

T17 PP: vada fino in fondo al corridoio

T18 G: questa è una forma::: formale ?

T19 F: deve ser

T20 G: vada ... ma possiamo usare vai

T21 J: uhm:: vai !

T22 PP: allora vada- perché usare vada anzi che va?

T23 V: perché è formale

T24 PP: sì perché è formale è un rapporto formale esattamente ... non sono amici non sono della stessa famiglia allora ... vada ... se fosse informale?

T25 G: vai

T26 J: vai

T27 F: va'

T28 PP: sì va'

T29 ??: qual' è la differenza:: fra:: va' e vai

T30 PP: vai è presente ... va' per l'imperativo

T31 G: é que a gente usa também como se fosse o imperativo né ? vai lá !

T32 J: ah va' !

T33 G: ((risos))

T34 PP: vada fino in fondo al corriduoio ... poi il numero due ?..........

T35 J: cadê o grande hotel majestic e onde a gente tá ?

T36 G: não- é onde a gente tá né ? ... a gente já tá aqui né ?

T37 J: nossa ! essa catedrale !

T38 G: bora ?

T39 J: ((risos)) 
T40 G: nossa é muito perto da catedrale

T41 J: é porque é em frente ((risos))

T42 G: ((risos))

T43 F: ah:: eu vou pra biblioteca

T44 J: biblioteca:::

T45 PP: avete trovato li l'holtel ? allora per questa attività potete anche usar ele espressioni que avete indicato nell'attività precedente ... ricordatevi di usarei 1 rapporto formale

T46 G: scusi ... eh... mi puoi aiutare a:: arrivare a::: al Mc Donald più vicino qua ?

T47 J: ah::: certo ... dove va a salire ?

T48 G: io sono al grande hotel majestic

T49 J: ahm::: deve (seguire) TF al fino dela mesma rua della mesma::: como é que fala rua ?

T50 G: via

T51 J: via

T52 G: o strada

T53 J: via::: dopo nel ristorante granel ... como que se fala vira?

T54 F: gira

T55 J: a destra

T56 G: (segue) TF a destra ... peraí ...

T57 J: deixa eu olhar aqui nas frases

T58 M: gira

T59 J: $\quad$ gira ... e gira a destra

T60 M: é mas fala é giri

T61 F: giri 